\title{
Technical guidelines for scientific surveys in the Mediterranean and the Black Sea
}

Procedures and sampling for demersal (bottom and beam) trawl surveys and pelagic acoustic surveys

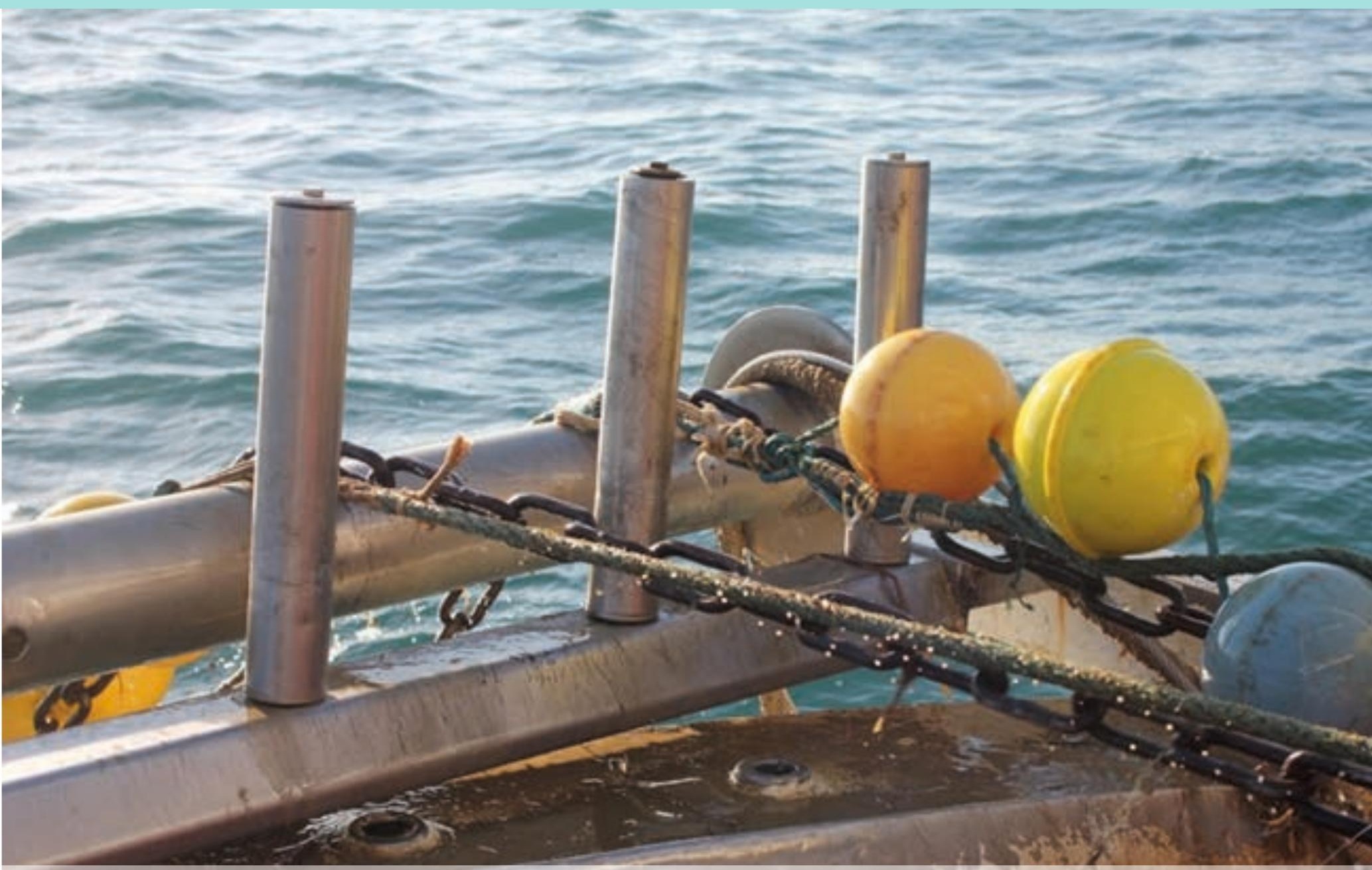


Cover photograph: (OFAO/P. Carpentieri 


\section{Technical guidelines for scientific surveys in the Mediterranean and the Black Sea}

\section{Procedures and sampling for demersal (bottom and beam) trawl surveys and pelagic acoustic surveys}

by

Paolo Carpentieri

Fishery Resources Monitoring Specialist

General Fisheries Commission for the Mediterranean

Food and Agriculture Organization of the United Nations

Rome, Italy

\section{Angelo Bonanno}

Consultant - Pelagic acoustic survey expert

General Fisheries Commission for the Mediterranean

Food and Agriculture Organization of the United Nations

Rome, Italy

and

Giuseppe Scarcella

Consultant - Beam trawl demersal survey expert

General Fisheries Commission for the Mediterranean

Food and Agriculture Organization of the United Nations

Rome, Italy 
Required citation:

Carpentieri, P., Bonanno, A. and Scarcella, G. 2020. Technical guidelines for scientific surveys in the Mediterranean and the Black Sea. FAO Fisheries and Aquaculture Technical Papers No. 641. Rome, FAO. https://doi.org/10.4060/ca8870en

The designations employed and the presentation of material in this information product do not imply the expression of any opinion whatsoever on the part of the Food and Agriculture Organization of the United Nations (FAO) concerning the legal or development status of any country, territory, city or area or of its authorities, or concerning the delimitation of its frontiers or boundaries. The mention of specific companies or products of manufacturers, whether or not these have been patented, does not imply that these have been endorsed or recommended by FAO in preference to others of a similar nature that are not mentioned.

This publication has been produced with the assistance of the European Union. The contents of this publication are the sole responsibility of FAO and can in no way be taken to reflect the views of the European Union.

The views expressed in this information product are those of the author(s) and do not necessarily reflect the views or policies of FAO.

ISSN 2070-7010 [Print]

ISSN 2664-5408 [Online]

ISBN 978-92-5-132555-1

(c) FAO, 2020

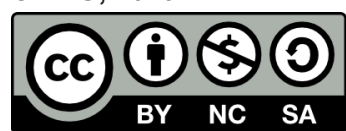

Some rights reserved. This work is made available under the Creative Commons Attribution-NonCommercialShareAlike 3.0 IGO licence (CC BY-NC-SA 3.0 IGO; https://creativecommons.org/licenses/by-nc-sa/3.0/igo/ legalcode).

Under the terms of this licence, this work may be copied, redistributed and adapted for non-commercial purposes, provided that the work is appropriately cited. In any use of this work, there should be no suggestion that FAO endorses any specific organization, products or services. The use of the FAO logo is not permitted. If the work is adapted, then it must be licensed under the same or equivalent Creative Commons licence. If a translation of this work is created, it must include the following disclaimer along with the required citation: "This translation was not created by the Food and Agriculture Organization of the United Nations (FAO). FAO is not responsible for the content or accuracy of this translation. The original [Language] edition shall be the authoritative edition."

Disputes arising under the licence that cannot be settled amicably will be resolved by mediation and arbitration as described in Article 8 of the licence except as otherwise provided herein. The applicable mediation rules will be the mediation rules of the World Intellectual Property Organization http://www.wipo. int/amc/en/mediation/rules and any arbitration will be conducted in accordance with the Arbitration Rules of the United Nations Commission on International Trade Law (UNCITRAL).

Third-party materials. Users wishing to reuse material from this work that is attributed to a third party, such as tables, figures or images, are responsible for determining whether permission is needed for that reuse and for obtaining permission from the copyright holder. The risk of claims resulting from infringement of any third-party-owned component in the work rests solely with the user.

Sales, rights and licensing. FAO information products are available on the FAO website (www.fao.org/ publications) and can be purchased through publications-sales@fao.org. Requests for commercial use should be submitted via: www.fao.org/contact-us/licence-request. Queries regarding rights and licensing should be submitted to: copyright@fao.org. 


\section{Preparation of this document}

These guidelines have been prepared by the General Fisheries Commission for the Mediterranean (GFCM) of the Food and Agriculture Organization of the United Nations (FAO) to address the priorities identified by Mediterranean and Black Sea countries in the context of existing international commitments and regional strategies. In particular, Target 1 of the mid-term strategy (2017-2020) towards the sustainability of Mediterranean and Black Sea fisheries (mid-term strategy) aims at reversing the declining trend of fish stocks through strengthened scientific advice in support of management. This document contributes to the objective of this strategy aimed at enhancing knowledge on Mediterranean and Black Sea fisheries through regional surveys-at-sea, namely acoustic surveys for pelagic species and bottom and beam trawl surveys for demersal species.

As it is difficult to gather information on the status of fish stocks in the context of multispecies and multigear fisheries in the Mediterranean Sea, fisheries independent data sources obtained through scientific surveys are very useful to acquire direct information on the state and dynamics of fish stocks and ecosystems and to improve the assessments based on the analysis of fishery-dependent data. Standardized time series are essential to provide information on the spatial and temporal variations in the abundance of commercial and non-commercial species as well as on the demographic attributes and other ecological indices of these species.

Within the GFCM, the Scientific Advisory Committee on Fisheries (SAC) and the Working Group on the Black Sea (WGBS) have highlighted the lack of survey data for some areas in the Mediterranean and the Black Sea and the need to harmonize the production and collection of such data across the region. Building upon the protocols already in place in the European Union - namely the Mediterranean International Bottom Trawl Survey (MEDITS), the Solea Monitoring Survey (SoleMon) and the Mediterranean International Acoustic Survey (MEDIAS) - these technical guidelines provide a framework for the implementation of harmonized regional and subregional scientific surveys in the Mediterranean and the Black Sea using a standardized methodology aimed at producing comparable results.

Experts in bottom, beam trawl and acoustic surveys, namely Giuseppe Scarcella and Angelo Bonanno, were tasked with developing these guidelines under the overall coordination of Paolo Carpentieri, GFCM Fishery Resources Monitoring Specialist, who ensured consistency with the methodologies in place and with GFCM priorities as well as applicability across the GFCM area of application.

A coordination meeting for the implementation of scientific surveys in the Mediterranean, organized in 2017 by the GFCM in Slovenia, gathered preliminary elements on acoustic and bottom trawl surveys, based on national experiences and on the outcomes of similar initiatives both in the European Union and at the international level. Technical consultations with experts involved in the BlackSea4Fish project also led to the integration of a section on beam trawl surveys. The draft guidelines were reviewed on the occasion of a workshop on the harmonization of data collection in scientific surveys-at-sea, held in 2019 in Bulgaria. In parallel, they were also presented to the Regional Coordination Group for the Mediterranean and Black Sea of the European Commission and at the MEDITS and MEDIAS Steering Committee meetings. These consultations contributed to the set-up of appropriate coordination mechanisms and helped fine-tune the methodology and align it to current practices so that it could be useful and replicable in different countries and areas. GFCM national focal points 
in Algeria, Egypt, Lebanon, Morocco and Tunisia already provided technical inputs as they prepared for the launch of their scientific surveys in 2019 and 2020, carried out with the support of the GFCM and the FAO regional projects and based on a standard methodology. Finally, the SAC and the WGBS reviewed and endorsed the final document for publication.

The editing, graphics, layout and publishing were coordinated by Dominique Bourdenet, GFCM Scientific Editor, with the assistance of Julia Pierraccini, GFCM Language and Communications Specialist, Lauriane Palopoli and Ysé Bendjeddou, GFCM Editing/Communications Interns. Barbara Hall served as language editor and Chorouk Benkabbour managed the graphic design and layout. Alberto Gennari produced and modified several illustrations based on existing materials.

This document was produced with the financial support of the European Union. The views expressed herein can in no way be taken to reflect the official opinion of the European Union. 


\section{Abstract}

There is increasing concern about species diversity, stock status and environmental conditions in ecology and conservation biology. Following investigations carried out in recent years at a local and regional scale, there is a growing need for large and multiscale data to increase knowledge on these aspects and determine how to maintain diversity. This is of particular importance in enclosed and semi-enclosed marine ecosystems such as the Mediterranean and the Black Sea, which are highly sensitive to human impacts.

In the Mediterranean and the Black Sea, demersal stocks are mainly assessed using data obtained through scientific demersal surveys (bottom and beam trawl), while pelagic stocks are assessed using data from acoustic surveys (i.e. using acoustic techniques together with mid-water trawling). These types of routine surveys provide essential information on many stocks and allow monitoring changes in species distribution and estimating annually the total mortality, growth parameters, sex ratios and average length at maturity of species so as to fine-tune assessments on the status of resources and to estimate indicators more precisely at the level of fish populations and communities.

However, scientific survey practices differ across subregions, each one having its own strengths and limitations, and there is still a lack of large-scale, standardized surveys devoted to analysing the diversity and distribution of the main demersal and pelagic species across the Mediterranean and the Black Sea. One solution to tackle this issue is to establish international scientific surveys covering the main demersal and pelagic stocks based on a common methodology.

The General Fisheries Commission for the Mediterranean (GFCM) has identified, among the main priorities of its mid-term strategy (2017-2020) towards the sustainability of Mediterranean and Black Sea fisheries (mid-term strategy), the need to develop a unique framework for the planning and implementation of regional demersal (bottom and beam) trawl and pelagic acoustic surveys based on existing protocols - namely the Mediterranean International Bottom Trawl Survey (MEDITS), the Solea Monitoring Survey (SoleMon) and the Mediterranean International Acoustic Survey (MEDIAS) that are being implemented in the European Union.

These technical guidelines aim at supporting this endeavour. Their use can serve different purposes: i) implementation of new surveys (applicable to areas where demersal trawl and/or pelagic acoustic surveys are not regularly carried out); ii) increasing comparability between existing surveys by standardizing methods, sampling of catches, and recording and analysis of data; and iii) definition of minimum requirements towards sustainability and management objectives (e.g. assessing the status of resources, establishment of management plans) at a regional and subregional scale. The guidelines cover Mediterranean and Black Sea priority species identified by the Scientific Advisory Committee on Fisheries (SAC) and the Working Group on the Black Sea (WGBS), based on the inputs of the Working Groups on Stock Assessment (WGSAs), and are in line with data collection requirements within the GFCM Data Collection Reference Framework $\left(\mathrm{DCRF}^{1}\right)$. They provide a useful tool for the collection of relevant complementary information on the incidental catch of vulnerable species, vulnerable marine ecosystems and non-indigenous species. Furthermore, scientific surveys can represent a valuable source of information on marine litter.

As the DCRF is updated on a regular basis, please check the DCRF section of the GFCM website for the latest version. 



\section{Contents}

Preparation of this document

Abstract

Acknowledgements

Acronyms

Background

1. DEMERSAL BOTTOM TRAWL SURVEYS

1.1 Aim

1.2 Vessel characteristics

1.3 Sampling gear

1.4 Survey design 6

$\begin{array}{ll}1.5 \text { Handling of the catch } & 10\end{array}$

1.6 Data reporting and exchange formats 16

2. PELAGIC ACOUSTIC SURVEYS

$\begin{array}{ll}2.1 \text { Aim } & 17\end{array}$

2.2 Vessel characteristics 18

$\begin{array}{ll}2.3 \text { Methodology } & 18\end{array}$

$\begin{array}{ll}2.4 \text { Period for and timing of pelagic acoustic surveys } & 18\end{array}$

$\begin{array}{ll}2.5 \text { Pelagic trawl } & 19\end{array}$

2.6 Oceanographic data $\quad 22$

2.7 Data reporting and exchange formats 22

3. DEMERSAL BEAM TRAWL SURVEYS 25

$\begin{array}{ll}3.1 \text { Aim } & 25\end{array}$

3.2 Vessel characteristics 26

3.3 Sampling gear 26

$\begin{array}{ll}3.4 \text { Survey design } & 29\end{array}$

$\begin{array}{ll}3.5 \text { Handling of the catch } & 31\end{array}$

3.6 Data reporting and exchange formats 34

4. ECOSYSTEM DATA 35

$\begin{array}{ll}4.1 \text { Macrobenthos } & 35\end{array}$

$\begin{array}{ll}4.2 \text { Vulnerable species } & 38\end{array}$

$\begin{array}{ll}4.3 \text { Marine litter } & 39\end{array}$

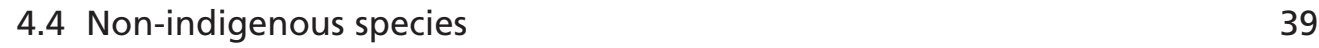

5. DATA POLICY 41

$\begin{array}{ll}\text { REFERENCES } & 43\end{array}$ 
$\begin{array}{ll}\text { ANNEXES } & 47\end{array}$

Annex 1. GFCM subregions and geographical subareas (GSAs) 49

Annex 2. List of priority species by subregion $\quad 50$

Annex 3. Fishing haul information 53

Annex 4. Catch composition by fishing haul 55

Annex 5. Length data by fishing haul 56

Annex 6. Individual weight by species $\quad 58$

Annex 7. Sex and maturity data 60

Annex 8. Maturity scales $\quad 64$

Annex 9. Six-phase maturity stages for anchovies and sardines caught in pelagic surveys 70

Annex 10. Maturity scale conversion table for anchovy (Engraulis encrasicolus) and sardine (Sardina pilchardus)

Annex 11. Reporting templates for bottom and beam trawl demersal surveys

Annex 12. Reporting templates for pelagic acoustic surveys 77

$\begin{array}{ll}\text { Annex 13. List of vulnerable species } & 79\end{array}$

Annex 14. Data entry sheet for vulnerable species $\quad 84$

Annex 15. Data entry sheet for marine macro-litter 85

Annex 16. Data entry sheet for macrobenthos 86

Annex 17. Scheme of the rapido trawl 87

\section{Tables}

Table 1. Relationship between depth $(m)$ and warp length $(m)$ for the trawl GOC 73 at different warp length diameters $(\mathrm{mm})$

Table 2. Depth strata (with surface in $\mathrm{km}^{2}$ ) and number of planned hauls per stratum and GSA

Table 3. Proposed minimum number of otoliths by length class per survey

Table 4. Taxonomy of small pelagic species of potential interest in performing a pelagic acoustic survey

Table 5. Priority species of potential interest for which a BTS could provide primary and/or additional data for tuning indices, by GFCM subregion 32

Table 6. Subsampling of epibenthic and benthic species, and debris fraction 


\section{Figures}

Figure 1. Main components of a demersal trawl net

Figure 2. GOC 73 trawl used for the MEDITS survey (acronyms specified for each netting)

Figure 3. Gear rigging details adopted for the MEDITS trawl 4

Figure 4. Main characteristics of the Morgere W horizontal (WH) otter board 5

Figure 5. Morgere WH S 8

Figure 6. Measurement of total (TL) and standard lengths (SL) in bony fish 12

Figure 7. Measurement of total (TL) and fork lengths (FL) in elasmobranchs 13

$\begin{array}{lll}\text { Figure 8. Measurement of carapace length (CL) for Decapoda crustacean } & 13\end{array}$

Figure 9. Measurement of dorsal mantle length (ML) of cephalopods 13

Figure 10. Example of an echogram acquired by a scientific split-beam echo-sounder $(38 \mathrm{kHz})$

Figure 11. Screenshots of a possible system for monitoring net sampling on small pelagic fish

Figure 12. Schematic representation and picture of the rapido trawl 27

Figure 13. Design of the rapido trawl net 28

$\begin{array}{ll}\text { Figure 14. Beam trawl scheme } & 28\end{array}$

$\begin{array}{ll}\text { Figure 15. Relationship between depth and warp length } & 29\end{array}$

\section{Plates}

Plate 1. Catch composition reaching a vessel deck (left) and sorting procedures (right)

Plate 2. Weighting and counting different species in the total catch

Plate 3. Invertebrates in catch composition (forming the megabenthos size $>2 \mathrm{~cm}$ )

$\begin{array}{ll}\text { Plate 4. Collection of total weight by species } & 14\end{array}$

$\begin{array}{lll}\text { Plate 5. Collection of individual weight } & 14\end{array}$

Plate 6. Results of a sampling activity by pelagic net 21

Plate 7. Results of biological sampling by pelagic net: species identification and separation

Plate 8. Measurement phases of biological samples 22

Plate 9. Catch reaching a vessel deck (left) and sorting procedures (right) 31

Plate 10. Various species of macroinvertebrates in a catch 36

Plate 11. Marine litter in catch composition 39 


\section{Boxes}

Box 1. Length data to be reported during a pelagic acoustic survey 23

Box 2. Age data to be reported during a pelagic acoustic survey 23

Box 3. The SoleMon survey in the northern Adriatic Sea (GSA 17) 26

Box 4. Mediterranean VME indicator: features (a), habitats (b) and taxa (c) 37

Box 5. Minimum set of data to be collected regarding the incidental catch of vulnerable species 


\section{Acknowledgements}

This document was prepared under the general supervision of Abdellah Srour, GFCM Executive Secretary, thanks to the expert guidance of Miguel Bernal, GFCM Senior Fishery Officer, with the support of Elisabetta Betulla Morello, GFCM Fishery Resources Officer, Margherita Sessa, GFCM Fishery Liaison Officer, and with the contribution of the staff of the GFCM Secretariat.

Special gratitude goes to the national focal points involved in the implementation of joint GFCM scientific surveys-at-sea and to the chairs and participants of the MEDITS and MEDIAS steering committees who provided their technical inputs, shared their direct experience and helped fine-tune the methodology. This publication builds upon the experience acquired through MEDITS and MEDIAS over the years and draws elements from their related manuals (in particular as far as gear and gear use are concerned). Warm thanks are due to all the people who have participated, directly or indirectly, in the scientific surveys already carried out and who have contributed to the development and improvement of common knowledge on fisheries ecosystems in the Mediterranean and the Black Sea. Finally, the original illustrations of the rapido trawl used in this document were kindly provided by Emilio Notti. 


\section{Acronyms}

$\begin{array}{ll}\text { BTS } & \text { Beam trawl survey } \\ \text { CL } & \text { Carapace length } \\ \text { CPCs } & \text { Contracting parties and cooperating non-contracting parties } \\ & \text { (GFCM) } \\ \text { CTD } & \text { Conductivity, temperature and depth } \\ \text { DCRF } & \text { Data Collection Reference Framework (GFCM) } \\ \text { EDSU } & \text { Elementary distance sampling unit } \\ \text { FAO } & \text { Food and Agriculture Organization of the United Nations } \\ \text { FL } & \text { Fork length } \\ \text { GFCM } & \text { General Fisheries Commission for the Mediterranean } \\ \text { GSA } & \text { Geographical subarea (GFCM) } \\ \text { IFREMER } & \text { Institut Français de Recherche pour l'Exploitation de la Mer } \\ \text { IUCN } & \text { International Union for Conservation of Nature } \\ \text { MEDIAS } & \text { MEDiterranean International Acoustic Survey } \\ \text { MEDITS } & \text { MEDiterranean International bottom Trawl Survey } \\ \text { ML } & \text { Mantle length } \\ \text { NASC } & \text { Nautical area scattering coefficient } \\ \text { SAC } & \text { Scientific Advisory Committee on Fisheries (GFCM) } \\ \text { SL } & \text { Standard length } \\ \text { SOLEMON } & \text { SOLEa MONitoring survey } \\ \text { TL } & \text { Total length } \\ \text { UNCLOS } & \text { United Nations Convention on the Law of the Sea } \\ \text { VME } & \text { Vulnerable marine ecosystem } \\ \text { WGBS } & \text { Working Group on the Black Sea (GFCM) } \\ \text { WGSA } & \text { Working Group on Stock Assessment (GFCM) }\end{array}$




\section{Background}

The establishment of pan-Mediterranean and Black Sea surveys has been motivated by the lack of comprehensive studies of the biological status of most demersal and pelagic fish stocks in some Mediterranean areas (GFCM, 2007; GFCM, 2017a, 2017b). To date, scientific surveys in the Mediterranean and the Black Sea have been carried out at an international scale, mainly covering European Union countries (Bertrand et al., 1997, 2002; AdriaMed, 2011; MEDITS, 2017; MEDIAS, 2019), with very few national surveys and varying degrees of comparability among surveys and countries. To effectively use survey information from all sources, the adoption of standard survey methods and stratification schemes is essential. Survey data throughout the Mediterranean and the Black Sea should be harmonized in order to capture the most relevant biological events and to allow for more accurate estimates of life history parameters such as mortality and growth. Since the boundaries of stock units are still not very well known for most Mediterranean species, the need for standardized indices of abundance and demography is a priority. Such data would provide valuable records to better assess the spatial occupation of the diverse components of stocks (e.g. seasonal distribution, spatial segregation, community structure and recruitment areas). This gain in accuracy would, in turn, sharpen the evaluation of variations in population indicators and input data/ parameters for population and community modelling.

At a coordination meeting for the implementation of scientific surveys in the Mediterranean, organized by the GFCM in 2017 (GFCM, 2017d), it was decided that the existing manuals already in use among some GFCM countries (MEDIAS, 2015; 2017; 2019; MEDITS, 2016; 2017; SoleMon, 2017; 2019) and covering both demersal (bottom and beam) trawl and pelagic acoustic surveys should be considered as the main references. The proposal was endorsed by the Scientific Advisory Committee on Fisheries (SAC) (GFCM, 2017a) and the Working Group on the Black Sea (WGBS) (GFCM, 2016, 2017b, 2019b). In terms of target species, this document addresses priority species identified by the SAC and the WGBS, on the basis of the work carried out by the GFCM working groups on stock assessment (WGSAs) and in line with existing data collection requirements within the GFCM Data Collection Reference Framework (DCRF). The list of target species, which is based on the existing manuals, may be complemented at a later stage with other species of regional or subregional interest (GFCM, 2017d; 2018a). 



\section{DEMERSAL BOTTOM TRAWL SURVEYS}

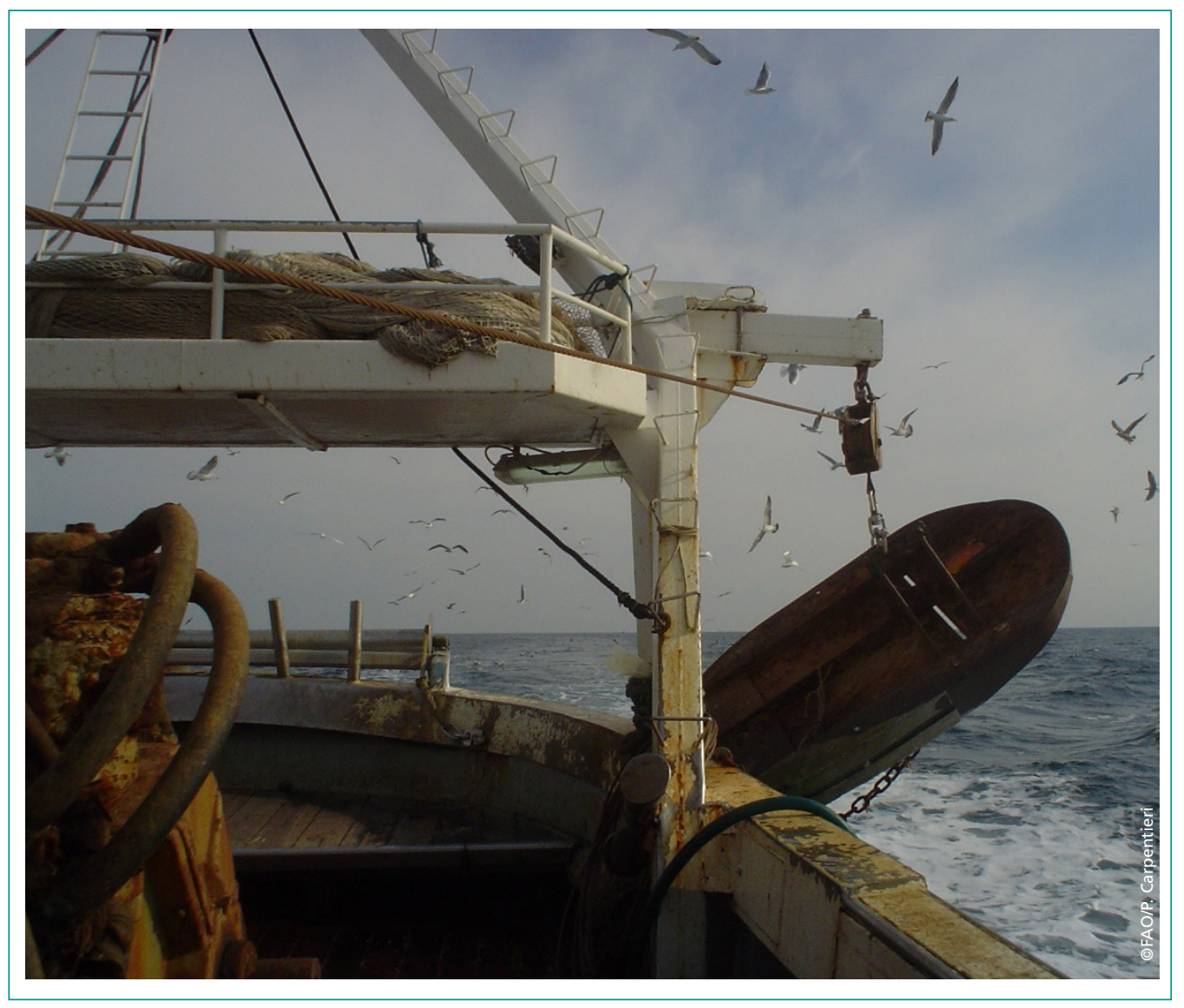

\section{$1.1 \quad$ AIM}

The aim of a demersal bottom trawl survey is to collect standardized fishery-independent data with a view to improving stock assessments. Demersal bottom trawl surveys should contribute to the characterization of fishery resources in a given area, in terms of population distribution (e.g. relative abundance indices) and demographic structure (e.g. length and sex distributions) as they collect data, including sex, maturity and weight, for the estimation of growth parameters of priority species. Thanks to the data obtained, it should be possible to compare catch composition in different areas, subregions and geographical subareas (GSAs) (GFCM, 2009; Annex 1) and to describe the spatial distribution pattern of all identified GFCM priority species (Annex 2), using the same gear specifications, to the extent possible.

The results of these surveys are crucial for the formulation of science-based advice on sustainable fisheries and conservation of stocks. In addition, the data collected should also be used for modelling the dynamics of the main target species in each GFCM subregion. Finally these surveys are also extremely useful to collect data on ecosystems (e.g. macrobenthos, several vulnerable marine species, and marine litter). 


\subsection{VESSEL CHARACTERISTICS}

For the correct implementation of a standardized demersal bottom trawl survey, commercial and/or research vessels should be equipped with an engine of at least $370 \mathrm{~kW}(500 \mathrm{hp})$ to be able to tow the standard sampling gear (traction at ground run: 4.5 tonnes) (Section 1.3).

Trawl speed during each fishing operation should be of about 3 knots. This recommended speed is very important to ensure the best trawl geometry. A speed lower than 2.8 knots can have a negative effect on the vertical opening of the net mouth and the stability of the doors, which can descend and become stuck in the mud. In deep waters, a speed greater than 3.2 knots can cause the gear to lift off the bottom and must be avoided (MEDITS, 2017).

During the survey implementation, the main information on each fishing haul (e.g. latitude, longitude, depth, speed, etc.) should be monitored and reported (see Annexes 3).

\subsection{SAMPLING GEAR}

The sampling gear for demersal trawl surveys should correspond to the bottom trawl (i.e. GOC 73, see Section 1.3.1) used to carry out the MEDITS, including all its material and rigging from the doors to the codend of the net (Relini, Carpentieri and Murenu, 2008; MEDITS, 2017). This was agreed by the GFCM survey coordination meeting (GFCM, 2017d) and endorsed by the SAC (GFCM, 2017a) and the WGBS (GFCM, 2017b). The adoption of this standard gear would permit comparability of data and results among countries and GSAs.

This gear constitutes a good compromise between different constraints (Bertrand et al., 1997, 2002): it has been planned with a vertical opening that is slightly superior to the most common commercial types of gear used in the Mediterranean and the Black Sea to increase the catch of demersal species (MEDITS, 2017).

Some general requirements and details regarding the mesh size, codend, otter boards and warps are provided in the following sections (a more detailed description of the gear is included in MEDITS, 2017).

For countries/GSAs where no demersal surveys have been previously carried out or where little information on sea bottom is available, it is suggested that exploratory fishing operations (e.g. fishing hauls/transects) should be carried out before the implementation of the standardized scientific survey with a commercial demersal trawl net (Figure 1). The bottom trawl used in this pre-survey should have a conical net bag with a wide mouth fitted with weights on the ground-rope and floats on the headrope.

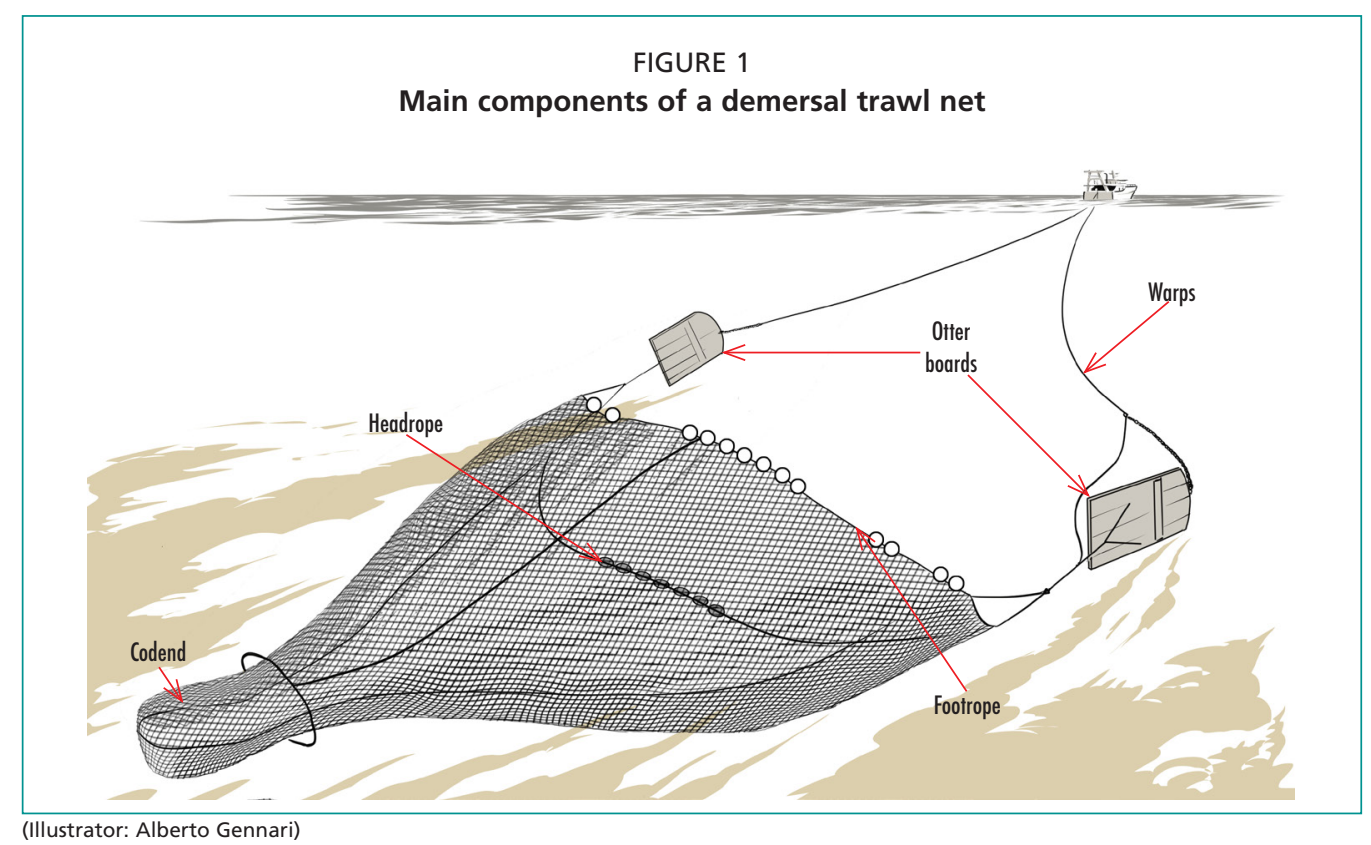


The use of a commercial trawl net would allow to better explore the bathymetry and the topography of the sea bottom. Based on the results of this pre-survey, the sampling scheme using the GOC 73 trawl gear (Section 1.3.1) designed by the Institut français de recherche pour l'exploitation de la mer (Ifremer) could then be used or modified.

\subsubsection{GOC 73 trawl gear}

All fishing hauls should be undertaken using a bottom otter trawl net with standard dimensions, i.e. the reference GOC 73 trawl designed for scientific purposes by Ifremer - width $22 \mathrm{~m}$, height of vertical opening $2 \mathrm{~m}$, length $40 \mathrm{~m}$, stretched mesh size at codend $20 \mathrm{~mm}$ (Fiorentini and Dremière, 1996; Fiorentini et al., 1999). Figure 2 shows a schematic drawing of the Ifremer GOC 73 trawl gear (MEDITS, 2017).

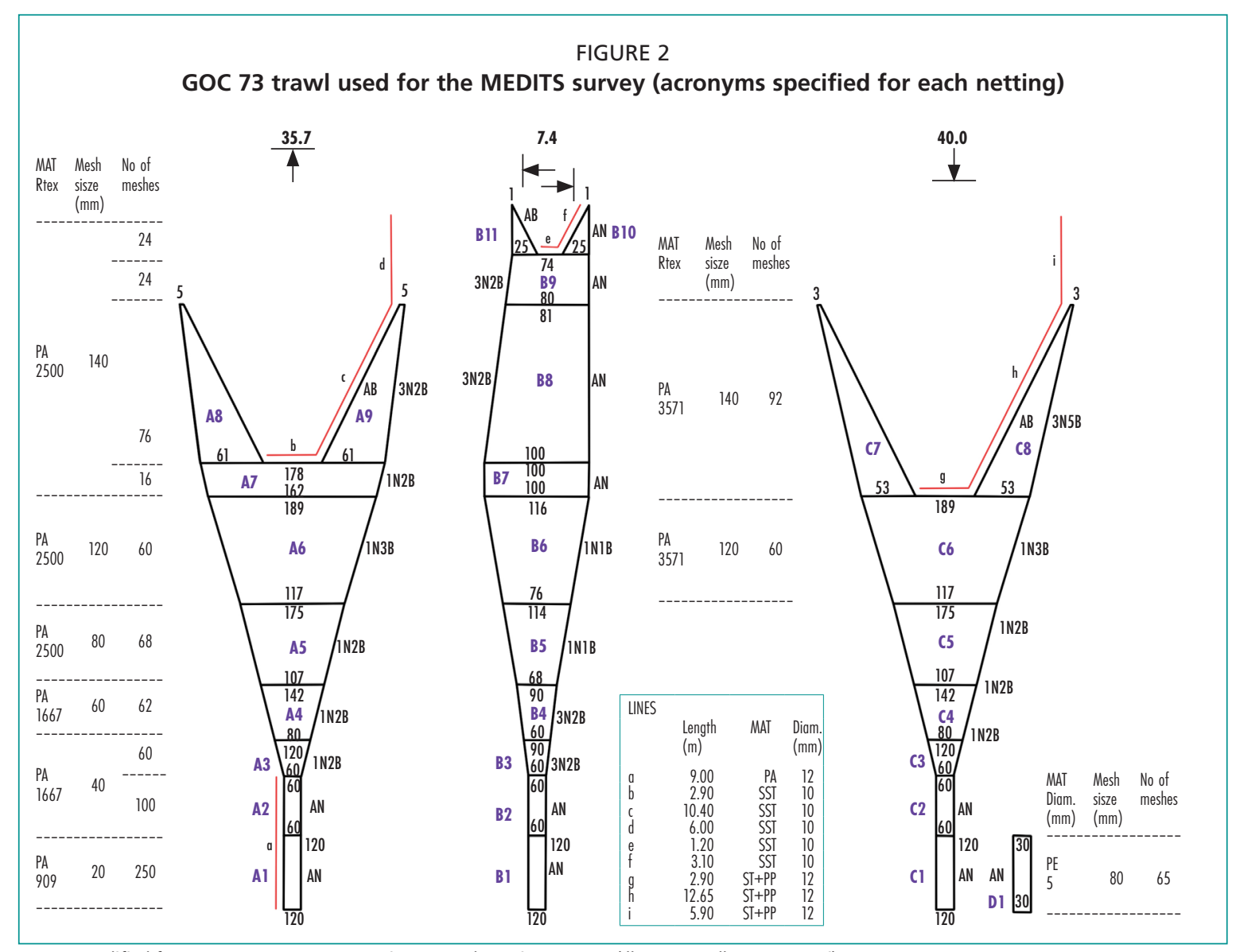

Source: Modified from MEDITS Survey - Instruction Manual, Version 9, 2017. (Illustrator: Alberto Gennari)

The most important specifications of this gear, also reported in the MEDITS manual (MEDITS, 2017), are the following:

- It is able to work from 10 to $800 \mathrm{~m}$ depth.

- It has low selectivity so as to have good images of the populations sampled, including recruits.

The mesh size of the codend should be $10 \mathrm{~mm}$ of mesh side, which corresponds to about $20 \mathrm{~mm}$ of mesh opening (stretch). In the International Organization for Standardization (ISO) 1107:2017, ISO defines the mesh side as "the distance between two sequential knots or joints, measured from centre to centre when the yarn between those points is fully extended".

The nets should be made of good-quality polyamide netting (nylon). The headrope should have around 40 floats, resisting to an immersion of $1300 \mathrm{~m}$ depth. Their diameter should be about $20 \mathrm{~cm}$, their individual buoyancy 2.7 kilograms-force per float (kgf) ( \pm 5 percent), with the total buoyancy of the 40 floats being some $108 \mathrm{kgf}( \pm 5$ percent). The floats should be distributed along the headrope as follows: 
- from the end of each wing, one float every $1.5 \mathrm{~m}$, five times;

- one pair of floats every $1.5 \mathrm{~m}$ on the whole remaining length;

- in the headrope bosom, a small adjustment of the spacing is necessary.

Based on this number of floats, the vertical opening of the trawl should reach from $2.4 \mathrm{~m}$ to $2.6 \mathrm{~m}$, being inversely related to the horizontal opening.

A weighting chain (ballast chain) of $120 \mathrm{~kg}(3 \times 40 \mathrm{~kg})$ should be secured to the foot rope at $17 \mathrm{~cm}$ intervals (with a hanging height of at most $8 \mathrm{~cm}$ ).

In addition, a supplementary chain (one only) of $15 \mathrm{~kg}$ (about $6.5 \mathrm{~m}$ with a diameter of $10 \mathrm{~mm}$ ) should be secured symmetrically on both parts of the belly bosom in the same way as the first chain (garland of $17 \mathrm{~cm}$ in length) (MEDITS, 2017).

\subsubsection{Rigging}

A general illustration of the rigging is presented in Figure 3 (MEDITS, 2017). The upper bridle length should be $30 \mathrm{~m}$ (C); the lower bridle length should be $29 \mathrm{~m}$, plus the adjustment chain of $1 \mathrm{~m}$ (the adjustment chain is only found on the lower legs) (D).

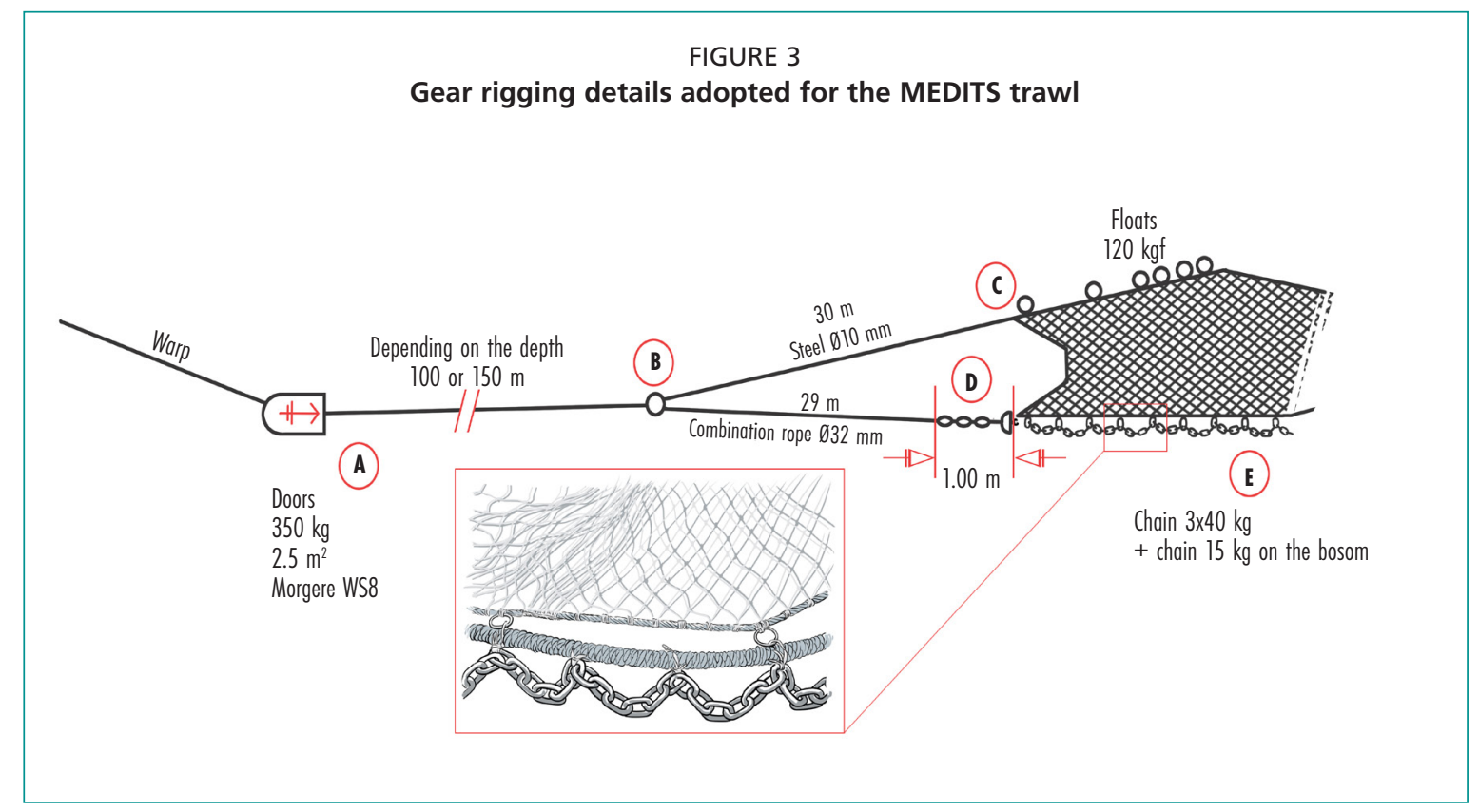

Note: The length of the $1 \mathrm{~m}$ chain (D) should be adjusted to obtain the upper (steel) and the lower bridle (combination rope + chain) of the same length ( $30 \mathrm{~m}$ ). Source: Modified from MEDITS Survey - Instruction Manual, Version 9, 2017. (Illustrator: Alberto Gennari)

In order to maintain the geometry of the trawl as constant as possible, two bridle lengths (MEDITS, 2017) are defined below according to the depth:

\begin{tabular}{|l|c|c|}
\hline Depth (in metres) & $10-200$ & $201-800$ \\
\hline Bridle lengths (in metres) & 100 & 150 \\
\hline
\end{tabular}

\subsubsection{Doors}

The doors should be of type Morgere W Horizontal: S (WH S, Figures 4 and 5), corresponding to size 8 . The length of the backstops (shackles not included) should be as follows (MEDITS, 2017):

- long external backstrops: $1.60 \mathrm{~m}$; and

- short upper and lower backstrops: $0.65 \mathrm{~m}$ ( \pm 10 percent). 
FIGURE 4

Main characteristics of the Morgere W horizontal (WH) otter board

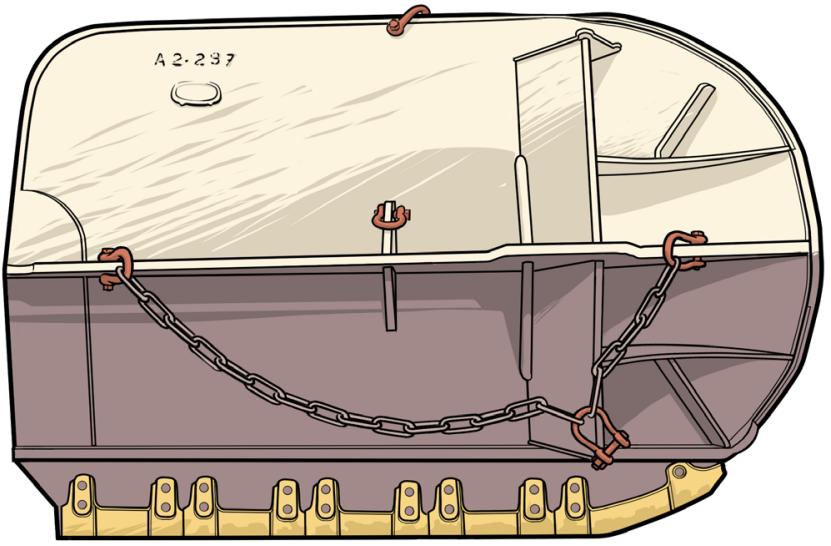

The otter board WH can be equipped with chain or with fixed bracket.

In the backside, the otter board can be equipped with 2 or 3 chains backstrop

\begin{tabular}{|c|c|c|c|c|c|c|c|}
\hline TYPE & DIMENSIONS & $\begin{array}{c}\text { SURFACE } \\
M^{2}\end{array}$ & $\begin{array}{l}\text { WEIGHT } \\
\text { KG }\end{array}$ & TYPE & DIMENSIONS & $\begin{array}{c}\text { SURFACE } \\
M^{2}\end{array}$ & $\begin{array}{c}\text { WEIGHT } \\
\text { KG }\end{array}$ \\
\hline WS 0 & $1050 \times 750$ & 0.70 & $60-100$ & WS 14 & $2650 \times 1700$ & 4.34 & $1000-100$ \\
\hline WS 1 & $1300 \times 850$ & 1.00 & $100-130$ & WS 15 & $2750 x 1750$ & 4.62 & 1300 \\
\hline WS 2 & $1500 \times 900$ & 1.12 & $110-150$ & WS 16 & $2800 x 1800$ & 4.90 & 1350 \\
\hline WS 4 & $1700 x 1050$ & 1.62 & $200-240$ & WS 18 & $3050 \times 2000$ & 5.70 & 600 \\
\hline WS 5 & $1750 \times 1100$ & 1.74 & $230-250$ & WS 19 & $3200 \times 2100$ & 6.10 & $1500-100$ \\
\hline WS 6 & $1900 x 1150$ & 1.96 & $250-300$ & WS 20 & $3400 \times 2200$ & 6.60 & 1900 1700 \\
\hline WS 9 & 2 150x1 300 & 2.62 & $380-500$ & WS 23 & $3750 \times 2500$ & 8.82 & $2300-2700$ \\
\hline WS 10 & $2300 x 1350$ & 2.82 & $500-700$ & WS 24 & $4000 \times 2700$ & 9.31 & $2300-3000$ \\
\hline WS 11 & $2400 x 1400$ & 2.93 & $600-700$ & WS 25 & $4300 \times 2900$ & 11.10 & $2500-4000$ \\
\hline WS 12 & $2500 x 1500$ & 3.30 & $750-900$ & WS 26 & $4600 \times 3200$ & 13.00 & $3000-5000$ \\
\hline WS 13 & $2600 \times 1600$ & 3.70 & $900-1000$ & WS 27 & $5000 \times 3500$ & 15.80 & $4000-6000$ \\
\hline
\end{tabular}

Note: For the MEDITS programme, the WS 8 type was selected. The otter board weight refers to without and with plates in the shoe. Source: Modified from MEDITS Survey - Instruction Manual, Version 9, 2017. (Illustrator: Alberto Gennari)

\subsubsection{Warp diameter and length}

Taking the characteristics of the trawl and rigging into account, the warps should have a diameter ranging between a minimum of $14 \mathrm{~mm}$ and a maximum of $22 \mathrm{~mm}$. The length of warps to be shot should be determined by the operating depth. Table 1 gives, by depth, different warp lengths to be shot at different depth in function of the warp diameter (from 12 to $22 \mathrm{~mm}$ ). The relationships are calculated based on the specifications of the GOV 73 net and the WS 8 doors (MEDITS, 2017). In addition, it is recommended that the warp length not be less than $200 \mathrm{~m}$, because this would considerably decrease the door spread, increasing door instability. 


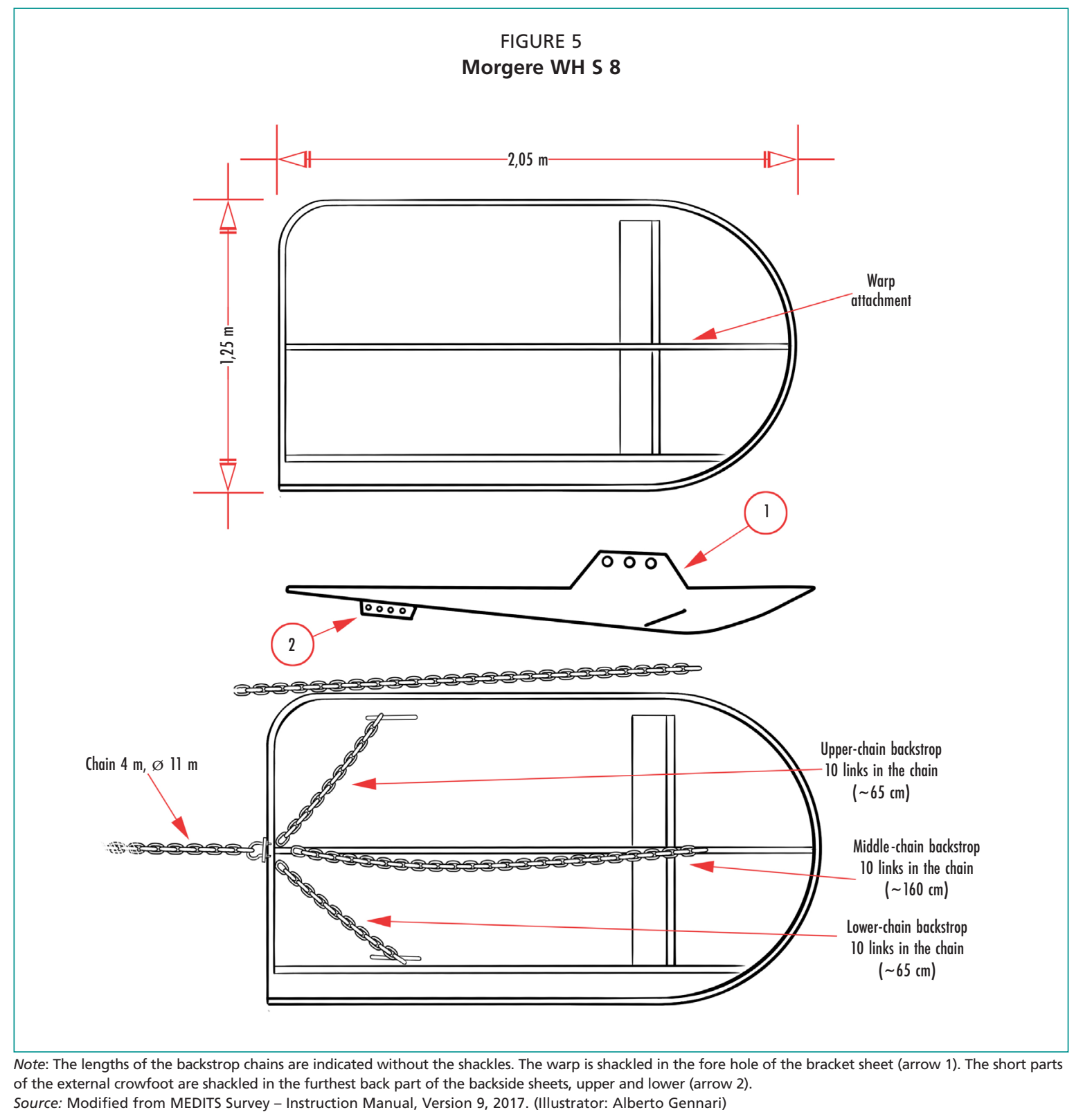

Although in particular circumstances some adaptations can be made to this relationship, it is recommended that the depth/warp length ratio be respected as far as possible. For vessels not equipped with a device to measure the length of warp shot, it is recommended to put a mark every 50/100 m directly on the warp to know how much cable is dropped.

\subsection{SURVEY DESIGN}

The aim of a demersal trawl survey is to cover the main distribution area of the target species. Demersal abundance is highly variable and large-scale trends related to habitat features, bathymetric and hydrographic conditions are evident. To exploit these trends to improve the precision of abundance indices, it is important to correctly allocate the trawl stations.

A procedure for the allocation of stations should be established. A fixed grid of stations ensures maximum information on distribution throughout the area, but not necessarily the most precise estimate of biomass (Sparre and Venema, 1998). For an estimation of stock sizes, a completely randomized design or a stratified random sampling design should be preferred. In most cases, a stratified random sampling design should be chosen, because fish are seldom uniformly distributed, and in most cases, species occurrence and abundance is related to depth (Sparre and Venema, 1998). 
TABLE 1

Relationship between depth $(\mathrm{m})$ and warp length $(\mathrm{m})$ for the trawl GOC 73 at different warp length diameters $(\mathrm{mm})$

\begin{tabular}{|c|c|c|c|c|c|}
\hline \multirow{2}{*}{ Depth (m) } & $\emptyset 12 \mathrm{~mm}$ & $\varnothing 14 \mathrm{~mm}$ & $\emptyset 16 \mathrm{~mm}$ & $\varnothing 18 \mathrm{~mm}$ & $\varnothing 22 \mathrm{~mm}$ \\
\hline & \multicolumn{5}{|c|}{ Warp length $(m)$} \\
\hline 10 & 200 & 200 & 200 & 200 & 200 \\
\hline 30 & 350 & 300 & 300 & 300 & 300 \\
\hline 50 & 400 & 350 & 350 & 350 & 350 \\
\hline 75 & 500 & 450 & 400 & 400 & 400 \\
\hline 100 & 600 & 550 & 500 & 450 & 450 \\
\hline 150 & 800 & 700 & 650 & 600 & 550 \\
\hline 200 & 950 & 850 & 800 & 700 & 650 \\
\hline 250 & 1100 & 1000 & 900 & 800 & 750 \\
\hline 300 & 1250 & 1150 & 1050 & 900 & 850 \\
\hline 350 & 1400 & 1300 & 1150 & 1000 & 950 \\
\hline 400 & 1550 & 1400 & 1250 & 1100 & 1050 \\
\hline 450 & 1650 & 1500 & 1350 & 1200 & 1150 \\
\hline 500 & 1750 & 1600 & 1450 & 1300 & 1250 \\
\hline 550 & 1850 & 1700 & 1550 & 1400 & 1350 \\
\hline 600 & 1950 & 1800 & 1650 & 1500 & 1450 \\
\hline 650 & 2050 & 1900 & 1750 & 1600 & 1550 \\
\hline 700 & 2150 & 2000 & 1800 & 1650 & 1650 \\
\hline 750 & 2250 & 2050 & 1850 & 1700 & 1700 \\
\hline 800 & 2350 & 2100 & 1900 & 1750 & 1750 \\
\hline
\end{tabular}

Source: MEDITS Survey - Instruction Manual, Version 9, 2017.

A stratified random sampling scheme has several advantages over a purely random scheme:

- Sampling is spread out over the entire area of the survey (e.g. GSAs) by assuring the required number of trawl stations in each stratum (e.g. bathymetric range).

- Sampling rates, in terms of stations per unit area, can be varied to improve the precision of estimates for some key species, this being an advantage over systematic sampling.

Trawl station location, depending on the characteristics of each area (see Section 1.4.1), can be randomly selected within an identified bathymetric stratum (e.g. 10-50, 51-100, 101-200 m, etc.) prior to each survey. The number of stations within each stratum should be generally proportional to the area of the stratum and also include consideration of the overall variability in multispecies distribution among strata.

Generally, the use of stratified random sampling enables the size of the contribution of sampling error to be controlled and estimated, and avoids possible biases in station selection.

\subsubsection{Survey area}

A demersal trawl survey should cover the main geographical and bathymetric range of the main species within a given GSA or a combination of GSAs according to the stock boundaries of the target species. The total covered area should be stratified according to depth and geographical criteria and, if known, fish density. Fishing positions must be chosen randomly in a first survey, but may be maintained as fixed stations during subsequent surveys. Information about depth and type of bottom to point out trawlable areas and strata may be obtained also from a preliminary survey with echo-sounding. Information from local fishers may also 
be valuable (Sparre and Venema, 1998). Information on seasonal winds, currents and migration patterns of fish stocks are important as well. Preferably, surveys in new areas should involve zones where commercial trawling is performed, using commercial hauls as a guide when deciding on sampling stations. This is essential due to the time constraints on performing the survey and also for safety reasons. Except in the case of particular problems (e.g. damages noted in previous years, etc.), once identified and selected, the same hauls position should be visited every year. According to Hilborn and Walters (1992) resorting the stations in each survey should allow a more accurate estimate of the standing stock in the investigated area, while keeping stations fixed over time should allow for more accurate information on time trends of relative abundance.

For conservation purposes, sensitive habitats (e.g. Posidonia spp. meadows, coralligenous beds), as well as vulnerable marine ecosystems (VMEs) (see Section 4.1) should be excluded from the sampling scheme and should never be trawled. All these aspects must be considered during the process of allocation of hauls to the different strata (Section 1.4.2).

\subsubsection{Depth strata and sampling stations}

Since bathymetry is the main factor affecting the distribution of demersal species, the trawl stations (or fishing hauls) should be allocated proportionally to the surface of each depth stratum, both over the shelves $(0-200 \mathrm{~m})$ and the upper slopes (> $200 \mathrm{~m})$. Then, based on the MEDITS manual (Relini, Carpentieri and Murenu, 2008; MEDITS, 2017), fishing hauls should be allocated among five main depth strata (i.e. 10-50 m, 51-100 m, 101-200 m, 201-500 m, > 501 m). Within each identified stratum, the position of the stations should be then selected randomly in the first survey. Each country performing a new survey will have to adapt the allocation of the fishing hauls based on the morphological and ecological features of the sea bottom.

Generally, the target average sampling rate should be about one station per 60 square nautical miles in all areas (Bertrand et al., 2002). To reduce or avoid covariance between fishing stations in adjacent strata, stations should be separated by at least 5-10 miles (ICES, 2010). Before the survey, it would be fundamental to set the surface area (in $\mathrm{km}^{2}$ ) and number of fishing hauls by GSA and for each identified stratum (Table 2).

TABLE 2

Depth strata (with surface in $\mathrm{km}^{2}$ ) and number of planned hauls per stratum and GSA

\begin{tabular}{|c|c|c|c|c|}
\hline Stratum & Code & GSA & Surface area $\left(\mathrm{km}^{2}\right)$ & Number of planned hauls \\
\hline $10-50 \mathrm{~m}$ & A & $\ldots \ldots .$. & $\ldots \ldots \ldots$ & $\ldots \ldots \ldots$ \\
\hline $51-100 \mathrm{~m}$ & B & ....... & $\ldots \ldots$ & $\ldots \ldots$ \\
\hline $101-200 \mathrm{~m}$ & C & ....... & ....... & $\ldots \ldots$. \\
\hline $201-500 \mathrm{~m}$ & $\mathrm{D}$ & $\ldots \ldots .$. & $\ldots \ldots$ & $\ldots \ldots$. \\
\hline$>501 \mathrm{~m}$ & $E$ & ....... & $\ldots \ldots$. & $\ldots \ldots$. \\
\hline
\end{tabular}

Note: This table, following stratification needs, should be prepared before survey implementation. 
The following formula should be applied (modified from Sparre and Venema, 1998) and can be used to estimate how many fishing hauls can be carried out in a given period:

- number of fishing hauls per day $=\mathrm{T} /\left(\mathrm{t}_{1}+\mathrm{t}_{2}+\mathrm{t}_{3}\right)$; and

- total number of fishing hauls during the survey $=(\mathrm{N}) *$ (number of fishing hauls per day).

\begin{tabular}{l|l}
\hline$N$ & Total number of days available to perform the survey \\
\hline$t_{1}$ & Duration of one fishing haul (average, hrs) \\
\hline$t_{2}$ & Time used for shooting and hauling the trawl (average, hrs) \\
\hline$t_{3}$ & Time to cover distance between fishing hauls (average, hrs) \\
\hline$T$ & $\begin{array}{l}\text { Number of hours available per fishing activity during the day } \\
\text { (depending on crew, behaviour of investigated species, navigation, etc.) }\end{array}$ \\
\hline
\end{tabular}

It is important to standardize the length of a fishing haul throughout the survey, because the catchability of species and sizes can be affected by the duration of the haul (Section 1.4.3).

In general, fishing hauls should be performed at constant depth. The depth variations during the haul should not exceed \pm 5 percent relative to the initial depth. As far as possible and in respect of the previous constraints, the hauls should be rectilinear.

The gear should stay in good contact with the seabed during the whole haul. This should be checked regularly by observation of chain wear, observation of benthic organisms in catches after the haul, and an acoustic device (if any) during the haul. The systematic use of a device (e.g. Scanmar, Simrad or other catch sensor) to control the trawl geometry (i.e. vertical and horizontal openings, contact with the bottom) is highly recommended.

When a device is not present, a proper contact could be indicated both by inspecting for chain/warp wear and for monitoring of warp widening and vibration. The measurements of the trawl geometry should be taken at various depths on board each vessel at the beginning of the survey to establish the relationship between the horizontal and vertical opening and parameters easy to measure, such as depth and/or warp length.

At deeper waters (i.e. more than $200 \mathrm{~m}$ ), some difficulties might be encountered in gear setting on the bottom; thus particular attention must be paid to the shooting operations. In order to decrease the setting time, the following recommendations should be considered (MEDITS, 2017):

- After the complete shooting of the warps and once the winch is stopped, a relatively high speed (5-6 knots) should be maintained for about one minute to stretch the gear and open the doors.

- The speed should then be strongly reduced (even to 0), allowing the doors to reach the seabed. The time required varies depending on the vessel and the depth, for example 2-3 minutes at $500 \mathrm{~m}$.

- Once the doors are on the seabed, a speed lower than normal (2.5-2.7 knots) should be maintained to allow the net to reach the bottom.

- Once the net is well stabilized, the speed will be increased towards the standard speed ( 3 knots); this moment is defined as the real start of the haul.

\subsubsection{Survey period and timing of fishing operations}

Demersal trawl surveys should be conducted annually, possibly during spring or summer (from 1 May to 30 September). This would permit greater comparability of data among GSAs and GFCM subregions (Annex 1). To properly carry out the survey, and based on the main biological aspects of the selected species (e.g. recruitments and spawning periods), the best month during this period should be selected.

Due to the different catchability of demersal resources according to the diel cycle, it is recommended to conduct trawling operations during daylight hours (i.e. between sunrise and sundown), although it is recognized that some institutes may wish to trawl 
both during the day and at night. More specifically, the daylight period is defined as the time between 30 minutes after sunrise and 30 minutes before sunset. Fishing hauls should have a duration of 30 minutes on bottoms shallower than $200 \mathrm{~m}$ and 60 minutes on bottoms deeper than $200 \mathrm{~m}$. For vessels using a device such as a SCANMAR Trawl Sensor or SIMRAD or other equivalent equipment, the start time of the haul is defined as the moment when vertical net opening and wing spread indicate that the net is in its stable fishing configuration (Engås et al., 2001; ICES, 2009; MEDITS, 2017). For the vessels without such a device, preliminary trials shall be made before the survey to determine the setting time needed to operate correctly for each vessel, taking into consideration the experience of each individual skipper, as well as the best predicting models of the net behaviour (e.g. horizontal and vertical net openings by warp length). Stop time is defined as the start of pull back (ICES, 2011). If the haul should be stopped before completion of the standard duration, it can be considered valid if at least two-thirds of the time or of the distance have been successfully attained (MEDITS, 2017).

It is strongly recommended that the sampling period of the survey is consistent yeartoyear to reduce the time-of-the-survey effect on the time series (ICES, 2012; MEDITS, 2017).

\subsection{HANDLING OF THE CATCH}

The organisation of work at sea mainly depends on the facilities available on board the vessel. Photos of whole catch should be systematically taken at each fishing haul. Wherever possible, the entire catch should be sorted (Plate 1), with all species (e.g. fish, cephalopods, crustaceans, etc.) identified to the lowest taxonomic level possible. However, as the level of taxonomic expertise on board vessels can be variable, and certain species can be hard to distinguish from one another, those could be reported by genus and/or higher taxonomic group (e.g. Nezumia spp. or Macrouridae).

Data on total catch composition (i.e. number and weight by species) for a single fishing haul can be collected and recorded as in Annex 4. For large catches, a representative subsample should be sorted. In some cases, the sample (e.g. nonidentified species, a subsample of huge catch, etc.) can be taken and preserved on board, and the biological analyses carried out at laboratories.

After the catch has been sorted, for each species, the total weight and number of individuals should be recorded (Plate 2). Length measurements and some other biological data (i.e. sex, maturity and weight) should be taken, at least for all identified target species (Section 1.5.1).

With the exception of decapod crustaceans and cephalopods, which should be recorded according to the standard templates ${ }^{1}$, the number and the total weight should be recorded for all other macroinvertebrates (Plate 3) (see Annex 16 and Section 4.1). In this sense, attention should be mainly focused on benthic species indicators of VMEs, as defined by the FAO (FAO, 2009; GFCM 2017a, 2017b; GFCM, 2018b, 2019a).

\subsubsection{Target species}

Although a scientific survey should aim to collect basic information on all species caught, the level of sampling requirements, based on time availability and human resources, will be different for all species observed in the survey. Hence, as a general principle, and in line with the requirements of the SAC and WGBS, the collection of basic data should be ensured to allow estimation of the distribution, abundance and key biological parameters (e.g. length, weight, sex and maturity) at least for all species of group 1 and group 2 (Annex 2) as requested by the DCRF (GFCM, 2018a). 
PLATE 1

Catch composition reaching a vessel deck (left) and sorting procedures (right)

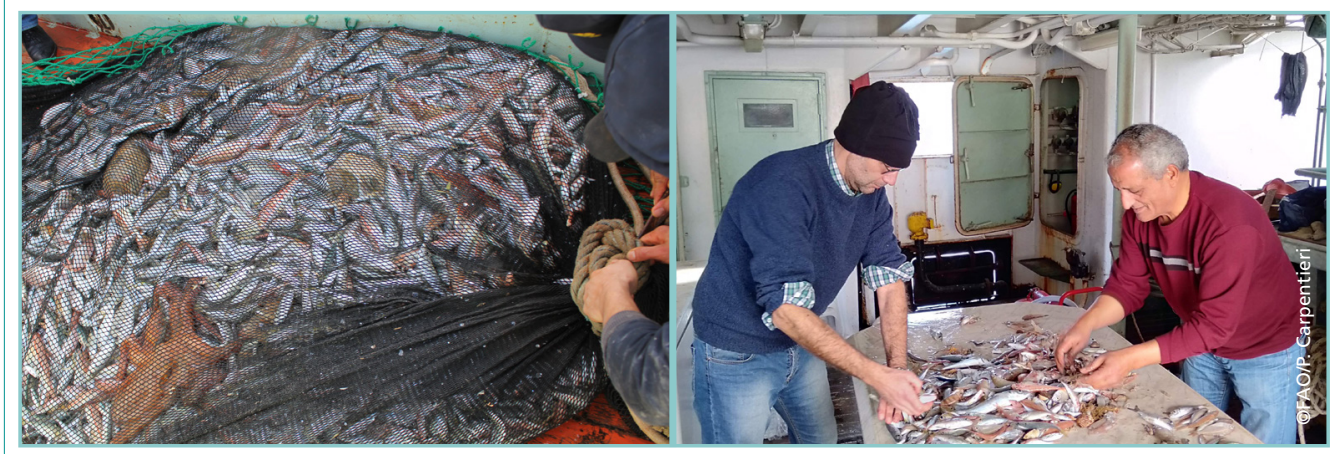

PLATE 2

Weighting and counting different species in the total catch

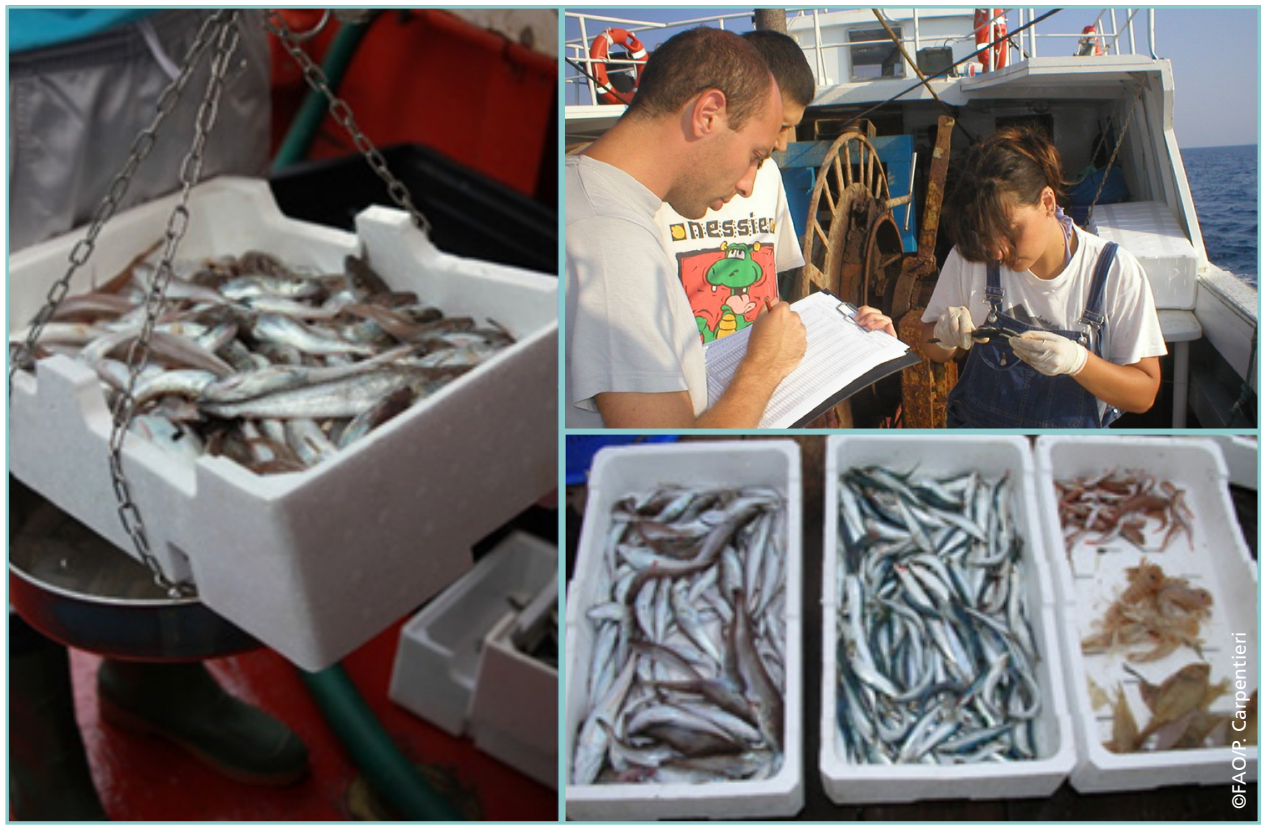

PLATE 3

Invertebrates in catch composition (forming the megabenthos size $>2 \mathrm{~cm}$ )

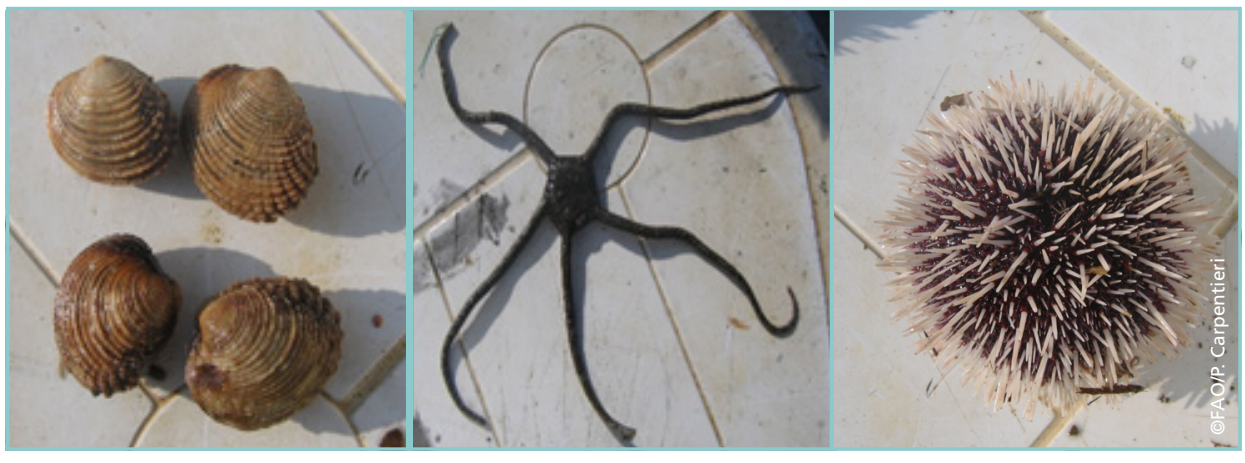


For all other sampled species of fish, crustaceans, molluscs and other invertebrates, data collection depends on time availability, but at least the total number and total weight by species should always be collected.

Moreover, since in recent years non-indigenous species have been pointed out as one the most important direct drivers of biodiversity and ecosystem service changes both in the Mediterranean and the Black Sea, particular attention should also be paid to collecting biological data (i.e. length, weight, sex and maturity) on this group of species. Survey information on non-indigenous species could contribute to understanding their roles in the benthic and pelagic ecosystems, their impacts on their new colonised environment, including restructuring established food webs, and competition with native organisms for food and space (see also Section 4.4).

\subsubsection{Biological parameters}

In order to allow an exhaustive and accurate processing of collected materials, individual biological data (length, weight, sex, maturity and otoliths reading) can be recorded either on board or in laboratory according to the work conditions (e.g. trawl surveys carried out by using an oceanographic vessel or a hired commercial trawler).

\subsection{2a Length measurements}

After sorting the catch into species, representative length distributions should be recorded for collected species (following the criteria described in Section 1.5.1), from high-priority species (i.e. group 1 and group 2 of Annex 2) to all others if time permits. Where the number of individuals is too high to measure them all, a representative subsample should be selected, from 50 to 100 specimens, depending on the species in each fishing haul. The length measurements to be taken depend on the group of species under study, and a proper representation of the given length distribution is key. Thus, attention must be given to a possible uneven distribution of species and/or size classes in the hold.

The methodology to be used for the collection and reporting of length data should follow the DCRF manual (GFCM, 2018a).

Bony fish and elasmobranchs - For bony fish, sharks, skates and rays, the length to be considered is total length (TL). The fish should be measured from the tip of the snout to the end of the caudal fin (Figures 6 and 7), to the lower half centimetre (e.g. $13.4=13 \mathrm{~cm} ; 16.8=16.5 \mathrm{~cm}$ ).

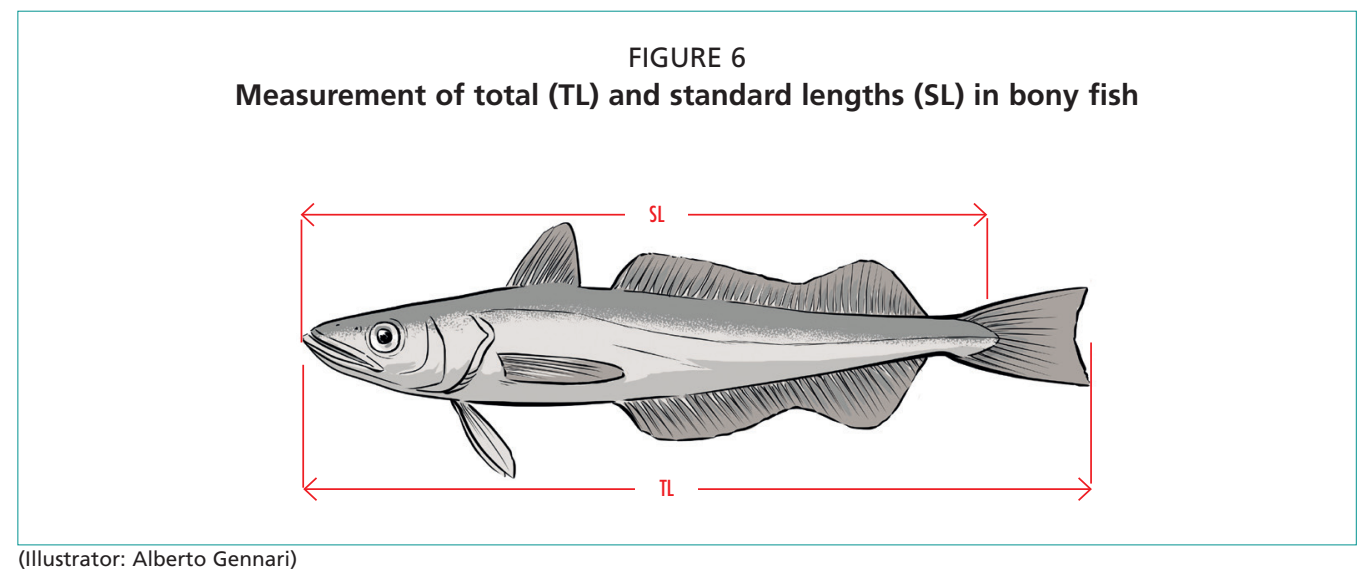

For bony fish, the standard length (SL) could be also recorded, which is defined as the measurement taken from the tip of the lower jaw to the posterior end of the hypural bone (Figure 6). For elasmobranchs, fork length (FL) can be recorded when the caudal fin is damaged and the TL cannot be measured (Figure 7). 


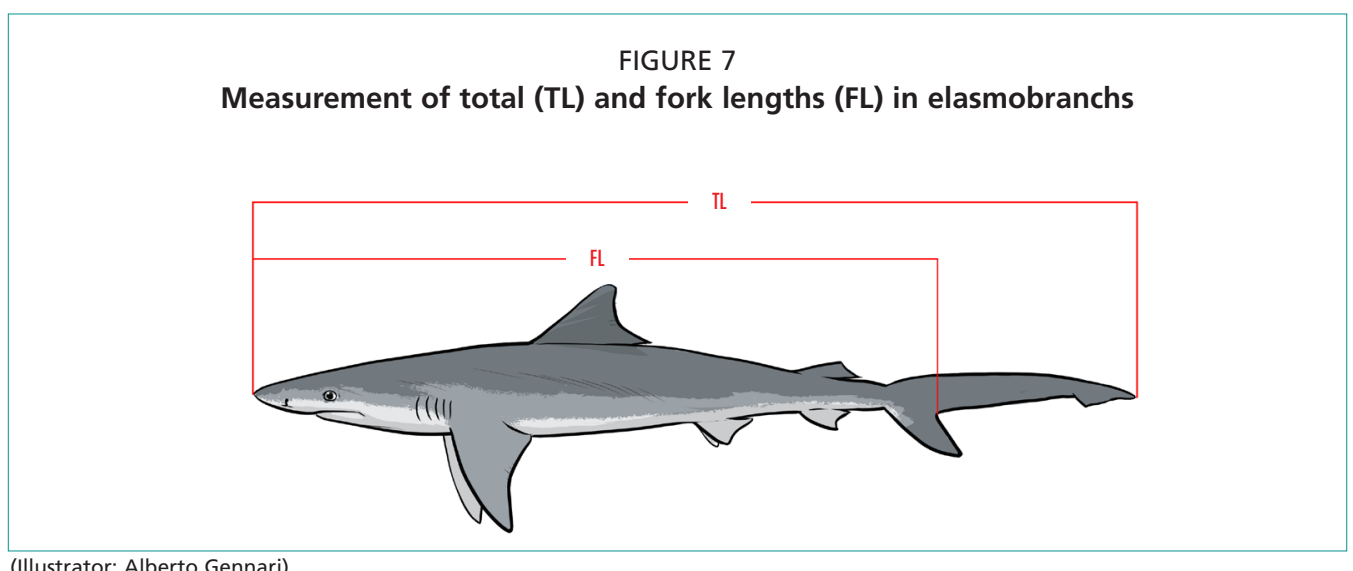

(Illustrator: Alberto Gennari)

Crustaceans - For crustaceans, the cephalothorax (carapace) length in millimetres should be reported to the lowest millimetre (as a whole number, e.g. 1, 2, 3, 4, etc.) (Figure 8).

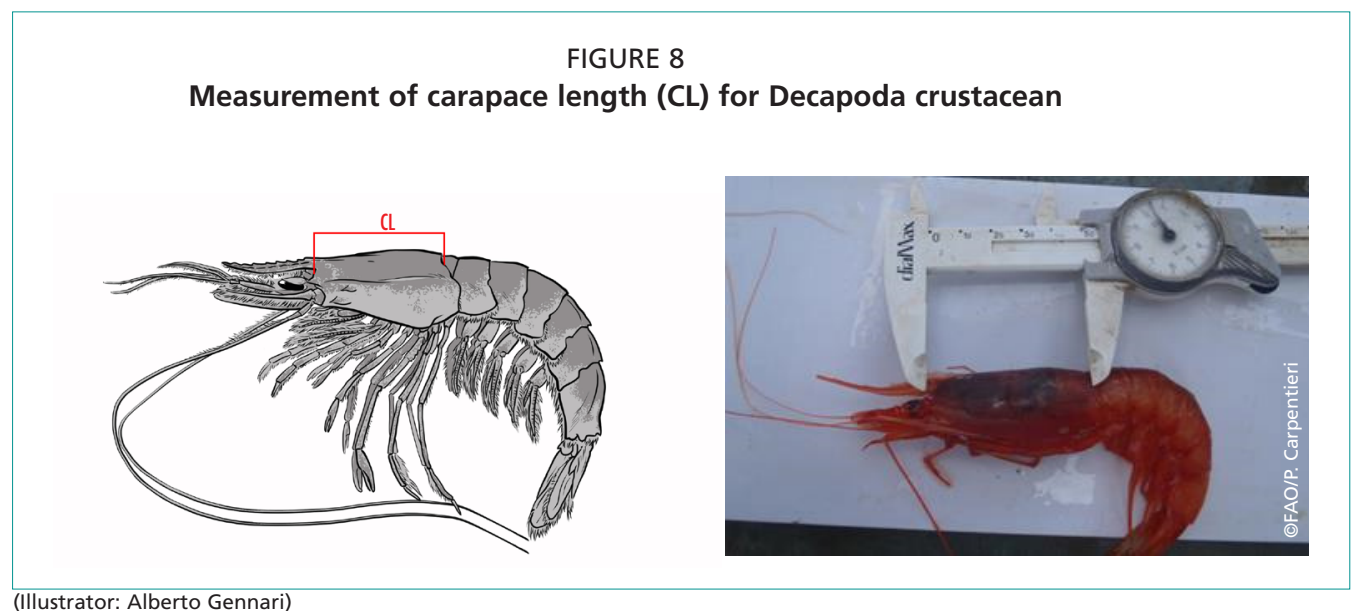

Cephalopods - For cephalopods, the mantle length in centimetres should be collected and reported to the lower half centimetre (as a whole or half number, e.g. 0.5, 1.0, 1.5, etc.) (Figure 9). For Octopoda, measurement is taken along the median line, passing through the eyes to the apex of the mantle (Figure 9a). For Decapoda, measurement is made along the dorsal midline from the mantle margin to the posterior tip of the body, excluding long tails (Figure 9b).

Length data for different groups of species can be collected and reported using the forms in Annex 5.

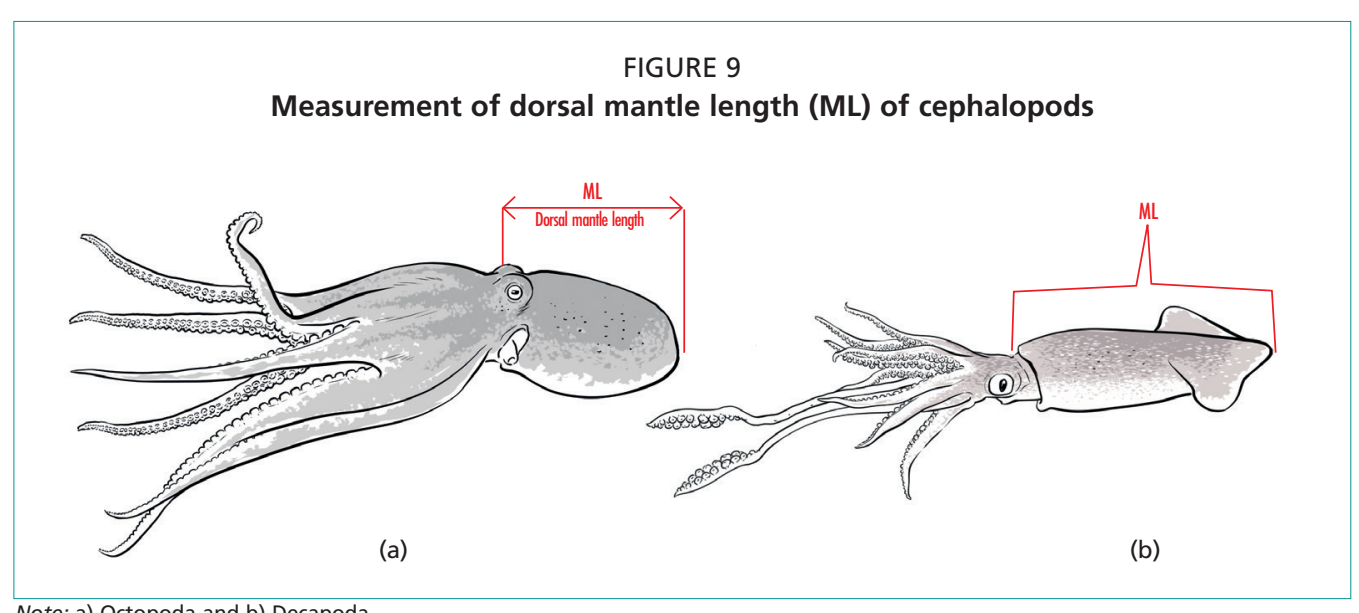

Note: a) Octopoda and b) Decapoda.

(Illustrator: Alberto Gennari) 


\subsection{2b Weight}

The total weight (in $\mathrm{kg}$ ) of all species (Plate 4 ) in the catch should be collected and recorded (Annex 4).

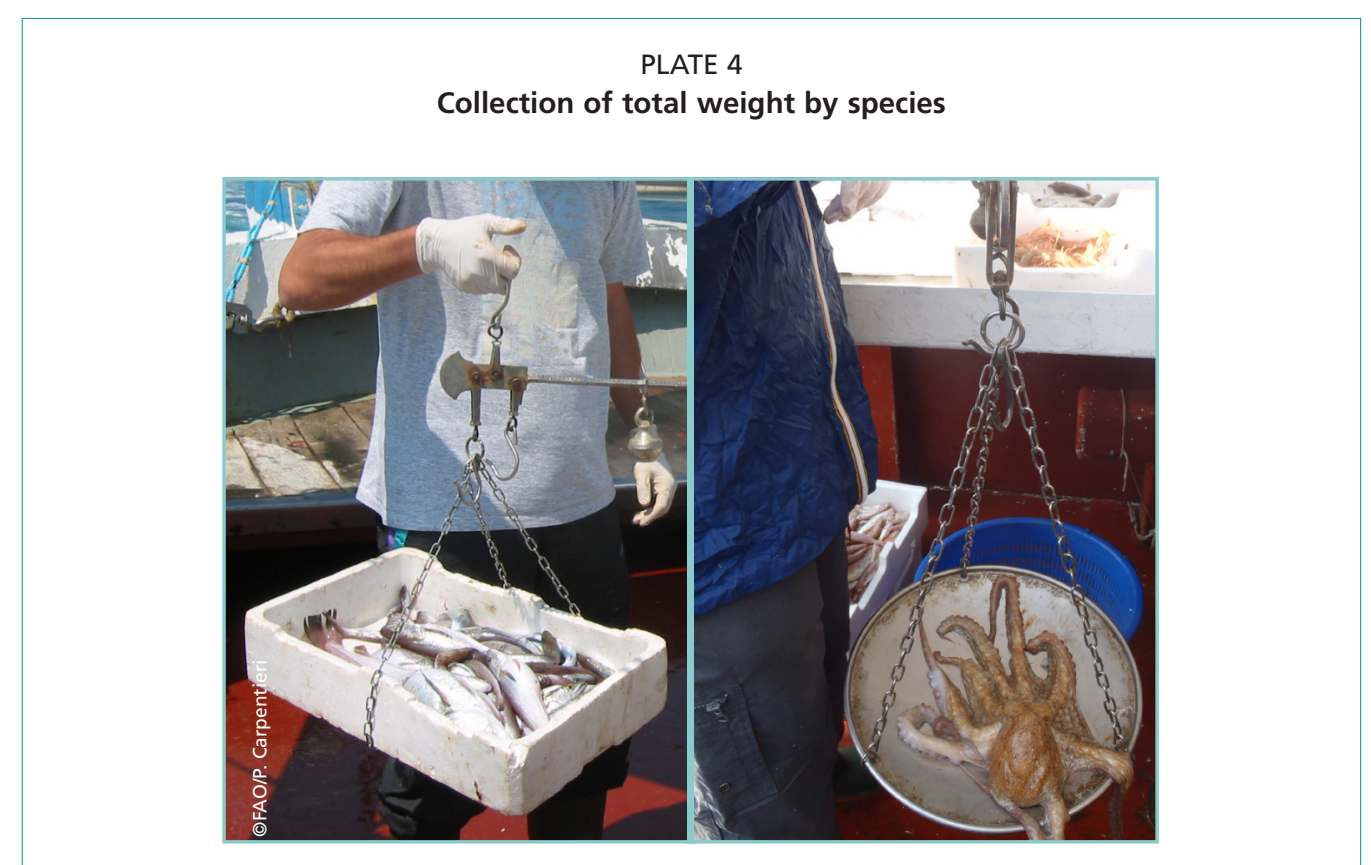

Individual weight should be collected and recorded (Plate 5) for at least all species of group 1 (Annex 6.1). The optimum number for individual weight per length class cannot be given in a universal form, but a minimum of five specimens per length class should be weighed.

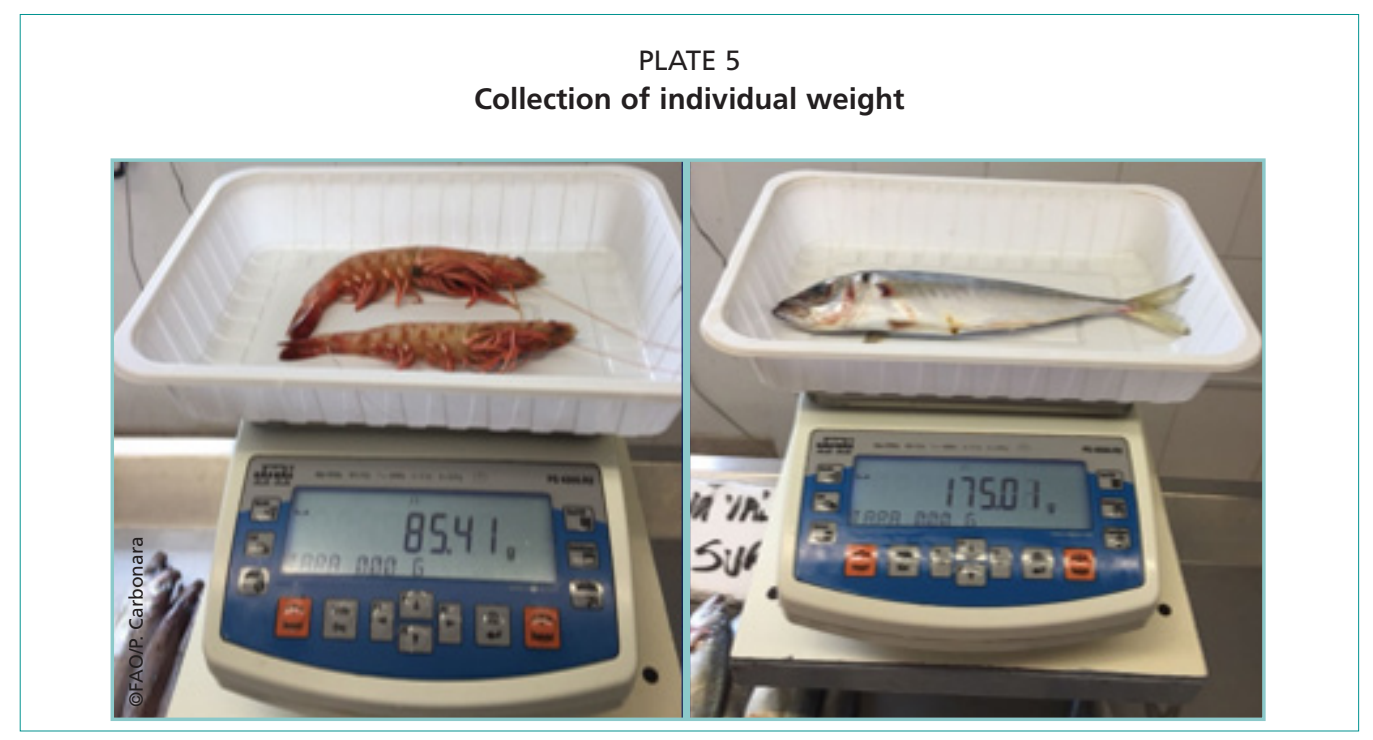

The choice of weighing device (e.g. hanging balance, electronic balance) depends on the size of the sampling and working conditions (on board or at laboratory). For fish, elasmobranch and cephalopod species, the total weight of each individual could be reported to the nearest gramme, using an electronic balance. For crustaceans, the weight should be recorded to the nearest $0.1 \mathrm{~g}$.

If it is impossible to measure individual weight, as a possible alternative, the number and total weight of a group of individuals with the same length should be recorded in order to calculate the mean weight of individuals in the length class (Annex 6.2). 
Although the weighing of single individuals may prove more complex, depending on prevailing conditions in the workplace, it is important to collect this biological information to the extent possible.

\subsection{2c Sex and maturity}

The sex is defined following four categories, through macroscopic observation: male $(\mathrm{M})$, female $(\mathrm{F})$, undetermined ( $\mathrm{U}$ - when, after dissection, it was not possible to determine the sex of different specimens with the naked eye), and not determined (ND - an individual that has not been examined). Sex and maturity data should be collected and reported (Annex 7) for the main priority species.

A large number of macroscopic maturation scales are available in the literature, varying from oversimplified scales comprising three to four stages to highly specific and relatively complicated scales (up to nine stages) (Follesa and Carbonara, 2019). For the purpose of this section, the maturity scales designed for scientific trawl surveys in other contexts should be used (MEDITS, 2017; see Annex 8)². Using common maturity scales would simplify data sharing and data quality checks.

\subsection{2d Otoliths}

Otolith samples can be collected on a "by need" basis, depending on the countries participating in the survey and on regional and/or subregional working group requirements. However, otoliths of routinely assessed species should always be collected for age estimation.

The technique for cutting otoliths depends on the species. For descriptions of these techniques (i.e. otolith sampling, preparation and reading) it is recommended to consult the literature on the subject (Carbonara and Follesa, 2019). The optimum number of otoliths per species and length class cannot be given in a universal form. A description of the optimum sample size of age readings and length measurements dependent on a universal cost function is given in Oeberst (2000) and in the Manual for Baltic International Trawl Surveys (ICES, 2011). The analyses showed that the necessary number of age readings in a length class depends on:

- the portion of the length class within the length frequency; and

- the maximum variance of the portions of the age groups within the length class.

Table 3 proposes a minimum number of otoliths by length class that must be taken per survey and species, based on length distribution. For the smallest sized groups, which presumably contain only one age group, the number of otoliths per length class may be reduced. Conversely, more otoliths per length are required for the larger length classes.

TABLE 3

Proposed minimum number of otoliths by length class per survey

\begin{tabular}{|l|l|}
\hline Criteria & Sample size \\
\hline With probably only one age group (age group 0, 1) & From 2 to 5 individuals \\
\hline \begin{tabular}{l} 
With probably more than one age group: \\
\hline $\begin{array}{l}\text { If the portion of any given length class is estimated as less } \\
\text { than } 5 \text { percent of total catch per species }\end{array}$
\end{tabular} & From 2 to 5 individuals \\
\hline $\begin{array}{l}\text { If the portion of any given length class is estimated as more } \\
\text { than } 20 \text { percent of total catch per species }\end{array}$ & Minimum 10 individuals per length class \\
\hline
\end{tabular}

Source: ICES, 2011.

Otoliths may be sampled during the survey if proper facilities and experienced people are on board and stored in envelopes or other suitable containers. The whole fish or its head can be stored for later processing in laboratory. In both cases, it is important, when otoliths are removed, that each single container be labelled with the identification code of

2 Collected maturity data, only for the purpose of the DCRF (GFCM, 2018a), should be submitted and reported with reference to the maturity scales based on DCRF rules and requirements (Recommendation GFCM/41/2017/6). 
the species and date. For each specimen, length, individual weight, together with sex and the maturity stage, should be also collected. Annex 6.1 can be used to report these data.

\subsubsection{Oceanographic data}

As a minimum, the following hydrographical data should be collected at each fishing haul:

- seawater temperature and salinity in the surface layer; and

- seawater temperature, salinity and oxygen content in the bottom layer.

Whenever possible, other parameters (e.g. turbidity, transparency, and current among others) from the surface to the bottom should be recorded. Annex 3.2 can be used to report all these hydrographical data.

\subsection{DATA REPORTING AND EXCHANGE FORMATS}

The outcomes of demersal trawl surveys should satisfy different data requirements within the GFCM:

- Relevant information should comply with DCRF provisions (GFCM, 2018a).

- Useful information in compliance with existing GFCM recommendations should be reported to the GFCM by its contracting parties and cooperating non-contracting parties (CPCs).

- Information supporting stock assessment should be reported to the different Working Groups on Stock Assessments (WGSAs) through stock assessment forms.

- Other relevant information useful for regional analysis can be examined in dedicated expert groups.

Standard templates ${ }^{3}$ are defined for the storage and exchange of data produced by demersal trawl surveys already conducted in some Mediterranean and Black sea countries (see also annexes from X to XIII in MEDITS, 2017). In order to have comparable and harmonized data, basic information on fishing hauls, catch and biological data should be reported, once collected, using these standard templates: i) Fishing hauls data (TA template; Annex 11.1); ii) Catch data by haul (TB template; Annex 11.2); iii) Biological data, length, sex, and maturity at aggregated species level (TC template; Annex 11.3); iv) Biological parameters at individual level (TE template; Annex 11.4) and v) Data on marine litter (TL template; Annex 11.5). The use of these standard templates should facilitate the exchange and analysis of the data produced by the demersal surveys among different countries.

In order to make proper use of the mentioned formats, ad hoc tool should be used and adapted (i.e. some fields should be revised, codifications are needed, among others) to the different needs of Mediterranean and Black Sea countries that are not currently involved in scientific surveys. Therefore, flexible routines for data conversion, from the input structure to the common formats (i.e. TA, TB, TC, TE and TL type formats), together with the complementary codification, will be made available to each country involved in a scientific survey.

This tool (i.e. MEDITS. Web application, COISPA Tecnologia \& Ricerca, 2020), is conceived taking into account the long and consolidated experience of the MEDITS trawl survey (MEDITS, 2017), in terms of standardised protocols for data collection and data format. This approach is integrated by introducing a wide flexibility to allow applications in other areas taking into account the specificities at sub-regional level while maintaining a common minimum standard. MEDITS. Web application has been realized for data input, import/export, storage, check and sharing. Besides the needed flexibility other basic concepts associated to the MEDITS. Web application are the data quality control check, data elaboration, data check procedures, which would permit to highlight errors that could compromise further analysis and make them unreliable.

All the templates are available for consultation and download in electronic format at: http://www.fao.org/gfcm/data/en/ 


\section{PELAGIC ACOUSTIC SURVEYS}

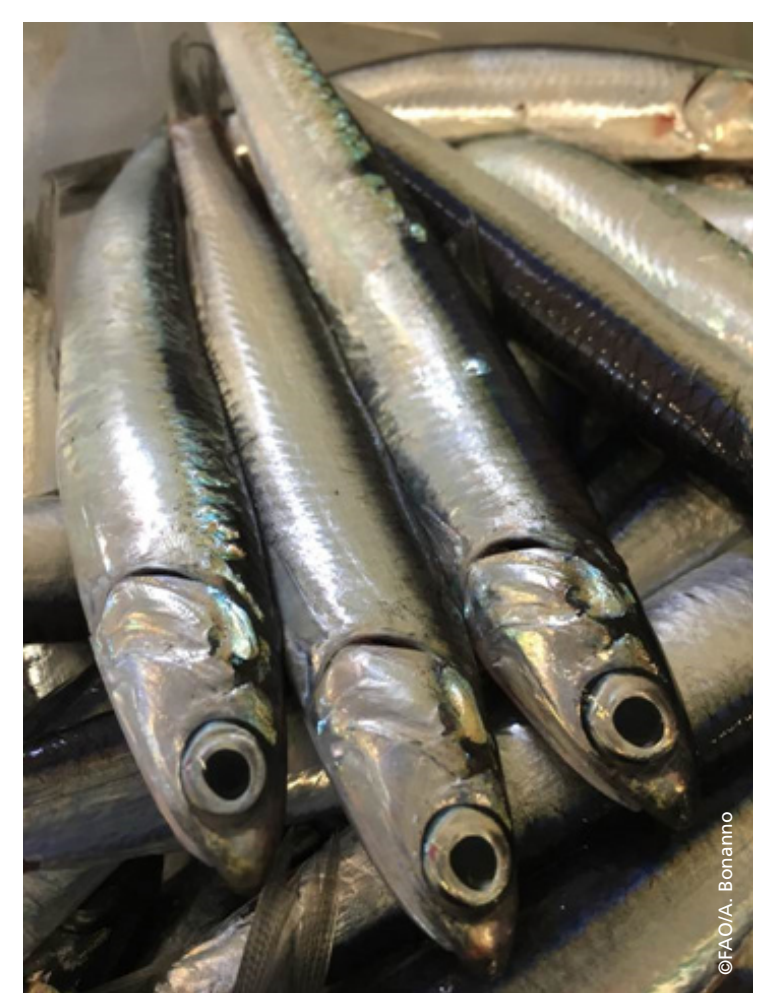

\section{$2.1 \quad$ AIM}

The main aim of a pelagic acoustic survey is to evaluate biomass and spatial distribution of the small pelagic fish species in given GSAs through the combined use of acoustic methods (Simmonds and MacLennan, 2005) and pelagic trawl. Consequently, data acquired during this survey should provide information on the pelagic fish community and on the pelagic environment.

The main species of the pelagic community, which could be sampled through the implementation of a pelagic acoustic survey in the Mediterranean and the Black Sea, are reported in Table 4.

TABLE 4

Taxonomy of small pelagic species of potential interest in performing a pelagic acoustic survey

\begin{tabular}{|c|c|c|c|}
\hline Family & Scientific name & English common name & FAO code \\
\hline Engraulidae & Engraulis encrasicolus (Linnaeus, 1758) & European anchovy & ANE \\
\hline Clupeidae & $\begin{array}{l}\text { Sardina pilchardus (Walbaum, 1792) } \\
\text { Sardinella aurita (Valenciennes, 1847) } \\
\text { Sprattus sprattus (Linnaeus, 1758) }\end{array}$ & $\begin{array}{l}\text { European pilchard } \\
\text { Round sardinella } \\
\text { European sprat }\end{array}$ & $\begin{array}{l}\text { PIL } \\
\text { SAA } \\
\text { SPR }\end{array}$ \\
\hline Carangidae & $\begin{array}{l}\text { Trachurus trachurus (Linnaeus, 1758) } \\
\text { Trachurus mediterraneus (Steindachner, 1868) } \\
\text { Trachurus picturatus (Bowdich, 1825) }\end{array}$ & $\begin{array}{l}\text { Atlantic horse mackerel } \\
\text { Mediterranean horse mackerel } \\
\text { Blue jack mackerel }\end{array}$ & $\begin{array}{l}\text { HOM } \\
\text { HMM } \\
\text { JAA }\end{array}$ \\
\hline Scombridae & $\begin{array}{l}\text { Scomber scombrus (Linnaeus, 1758) } \\
\text { Scomber japonicus (Houttuyn, 1780) }\end{array}$ & $\begin{array}{l}\text { Atlantic mackerel } \\
\text { Chub mackerel }\end{array}$ & $\begin{array}{l}\text { MAC } \\
\text { MAS }\end{array}$ \\
\hline Sparidae & Boops boops (Linnaeus, 1758) & Bogue & BOG \\
\hline
\end{tabular}

Note: this list of species could be subject to changes based on countries and regional/subregional needs. 


\subsection{VESSEL CHARACTERISTICS}

It is highly recommended, whenever possible, that research vessel are used for acoustic surveying at sea. Vessels should be equipped with hull-mounted transducers for both the scientific echo-sounder and the net-sounder. Furthermore, vessels should be equipped with an engine capable of towing the sampling gear (maximum traction about 4.5 tonnes) (see Section 2.5).

\subsection{METHODOLOGY}

The survey design for acoustic sampling is strongly dependent on both the spatial structures of small pelagic fish and the topographic characteristics of the area to be investigated.

The survey should cover the sea area between the coastline and the limit of the continental shelf. The minimum bottom depth should be $20 \mathrm{~m}$ or less, reaching the $10 \mathrm{~m}$ isobaths whenever possible. The maximum echo-sounding depth should be $200 \mathrm{~m}$. The intertransect distance to be adopted should be carefully determined based on the continental shelf extension and, if available, on specific knowledge of the ecological characteristics of the area.

\subsection{PERIOD FOR AND TIMING OF PELAGIC ACOUSTIC SURVEYS}

In the Mediterranean, pelagic acoustic surveys should be conducted annually, possibly during spring or summer (between May and September). In the Black Sea, surveys should be carried out in the period from spring to autumn (between April and November). Each Mediterranean and Black Sea country, based on the main biological aspects of the identified priority species (e.g. recruitments and spawning periods), should select the best month during these periods to carry out the survey. This would permit greater comparability of data among areas and GFCM subregions.

Acoustic surveys should only take place during daytime and should be interrupted at night, when fish schools disperse. This approach would prevent possible bias in the biomass estimation due to the different aggregation status of fish species. If available survey time does not permit acquisition of data only during daytime, echo sampling might be extended. Previous studies had indicated that night estimates can be higher or lower than daytime estimates, largely depending on the area characteristics and, especially, the local plankton and fish densities (Simmonds and MacLennan, 2005; Draštík et al., 2009). However, results showed that correction is possible and advisable when night sampling is inevitable. In this context, and depending on the available vessel time, it is good practice to identify specific test areas where acoustic data are recorded both in the daytime and at night. Test areas should be selected considering:

- the extension of the continental shelf;

- specific geographical characteristics (e.g. the presence of gulfs); and

- oceanographic processes such as the presence of specific enrichment processes driving the productivity of the area (e.g. upwelling events, river runoff, tidal mixing).

\subsubsection{Analysis design}

For countries/GSAs where acoustic surveys have been performed, the acoustic survey design is already established and, if necessary, could be adjusted to achieve minimization of the coefficient of variation of the acoustic estimates for the priority species in each area.

For countries/GSAs where no acoustic survey has been previously carried out, it is suggested that parallel transects be adopted along the depth gradients (i.e. bottom topography), which are normally perpendicular to the coastline/bathymetry. In cases of topographic complexity, as with semi-closed gulfs, riverine areas or islands, survey design could be decided in another manner (see Simmonds and MacLennan, 2005). 


\subsubsection{Echo sounder parameters}

A scientific split-beam echo-sounder should be used for the acoustic survey (Figure 10). Pulse duration should be 0.5 or 1 millisecond (ms), depending on the technical specifications of each echo-sounder. The frequency for assessment should be 38 kilohertz $(\mathrm{kHz})$, while other split beam transducers can operate as complementary frequencies (e.g. 18, 70, 120 and $200 \mathrm{kHz}$ ).

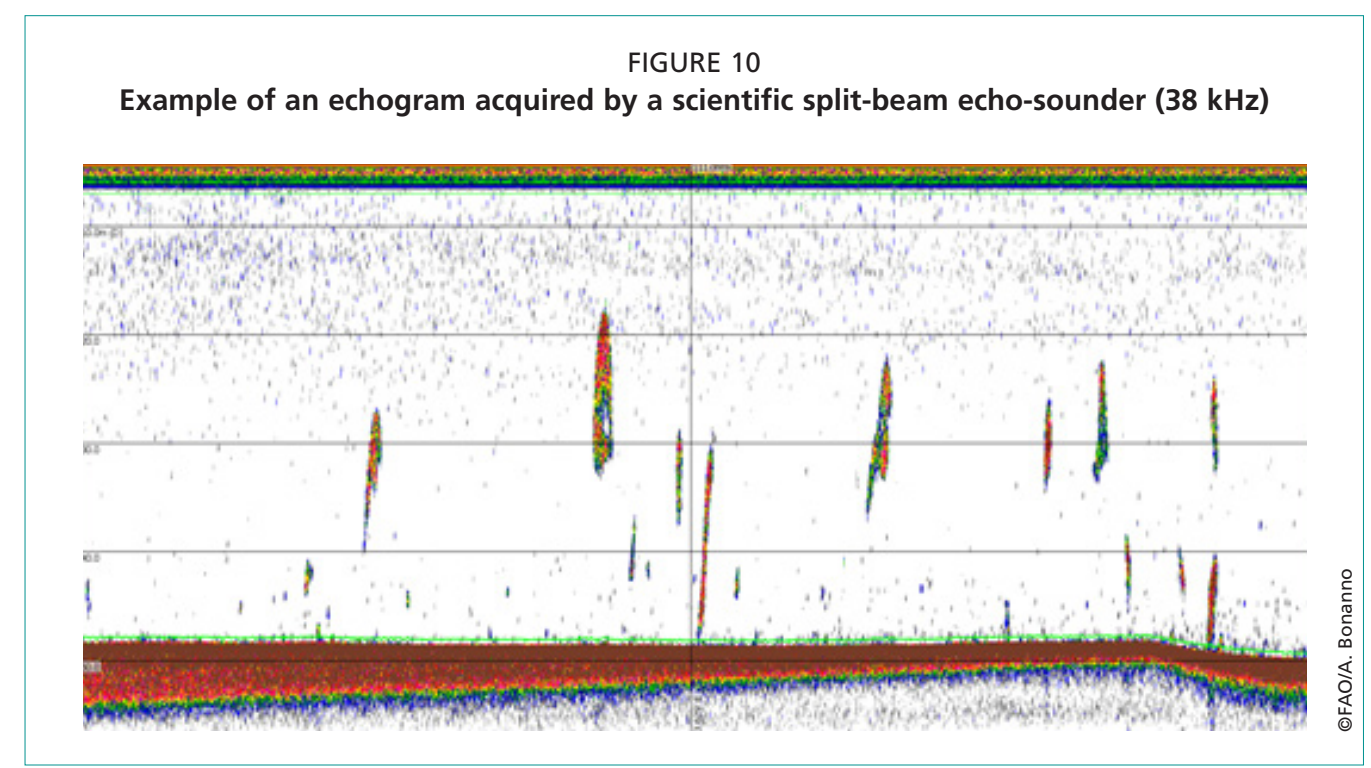

The threshold for assessment should be -70 to $-60 \mathrm{~dB}$, depending on the survey and the ecosystem. Background noise should be evaluated and removed. Since the main objective is optimum discrimination between fish and plankton, based on the available frequencies used in each survey, a frequency-response-based mask should be developed to split the acoustic backscattering between fish and plankton. Whenever this cannot apply, the threshold for assessment should be set at -70 to $-60 \mathrm{~dB}$, depending on: (a) noise level (-60 $\mathrm{dB}$ in the case of high noise); (b) the peculiarities of each area regarding school morphology and plankton density $(-60 \mathrm{~dB}$ when plankton is dense, but $-70 \mathrm{~dB}$ when small schools dominate the area); (c) echo-sounder features; and (d) time of day that echo acquisition is carried out.

The elementary distance sampling unit (EDSU) for echo integration should be one nautical mile (NM). The acoustic energy acquired in the inter-transect tracks should not be taken into account for assessment purposes.

At least one calibration of echo-sounder should be held per survey, based on the procedure reported in the manual of each echo-sounder and according to the principles described by Foote et al., (1987) and Demer et al., (2015).

\subsection{PELAGIC TRAWL}

Implementing acoustic surveys means acquiring both acoustic data and net samplings of small pelagic fish with a pelagic trawl (i.e. pelagic fishing hauls). The details of each pelagic trawl haul (e.g. latitude, longitude, depth, time) should be monitored and reported as in Annex 3.1. Furthermore, temperature, salinity and other parameters from the surface to the bottom should be sampled. Annex 3.2 can be used to report these data.

The main objectives of trawling in an acoustic survey are to obtain a sample from the schools or layers that appear on the echograms and to acquire information on fish species composition and size distribution. Thus, it is important that the trawling gear be suitable for catching a representative sample of the target schools or layers. 
In an acoustic survey, the sampling intensity for biological samples depends on the extent of the area covered, the frequency of occurrence of different echo traces on the echograms, and on the spatial characteristics of fish aggregations. The presence of specific behavioural effects, such as the spatial segregation between different age/length classes, should be considered in order to sample the whole fish population. In addition, the geographical coordinates or the sampling depth of the hauls cannot be predetermined, because pelagic species execute extended horizontal and vertical movements. School morphometry and energetic characteristics might change depending on the area, the time interval or even the fishing pressure. Thus, the sampling strategy has to be adaptive, depending on school characteristics per area, time of the survey and year.

It is recommended to use a net monitoring system (a net-sounder) during trawling operations (Figure 11).

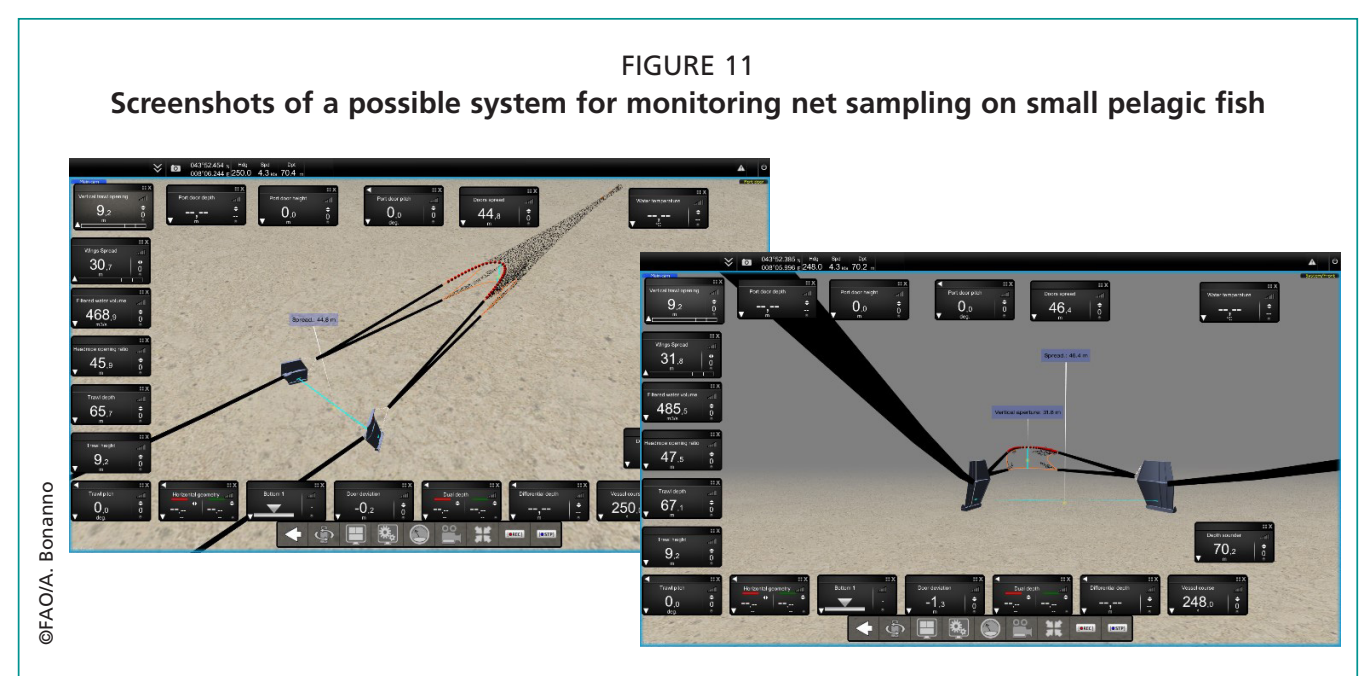

Given the fact that different research vessels are expected to be used in the GSAs in the Mediterranean and Black Sea, as a minimum, the following indications should be adopted:

- A standardized pelagic trawl net should be used in all areas for biological sampling.

- Maximum codend mesh size should be equal to $24 \mathrm{~mm}$ (mesh size equal to $12 \mathrm{~mm}$ ).

- The vertical opening during the pelagic fishing hauls should be reported, along with the net-sounder used.

- The duration of fishing hauls should be no less than 30 minutes for unknown echoes and when multispecies scattered echoes are being fished.

- Vessel speed during fishing should be 3.5-4.5 knots.

- Sampling intensity must be adequate to ensure identification of echo traces, to obtain a representative length structure of the population for each small pelagic species, and to evaluate the species composition of the insonified target in the water column.

\subsubsection{Handling of the catch}

Once on board the vessel, the biological sample collected during each pelagic haul should be divided by species (Plate 6).

All species in the catch should be recorded. Data (i.e. length and weight) on total catch composition for single pelagic haul and by species should be collected and reported as in Annex 4. When the catch of a given species is too abundant, a representative subsample of the whole catch should be randomly selected (Plate 7). 

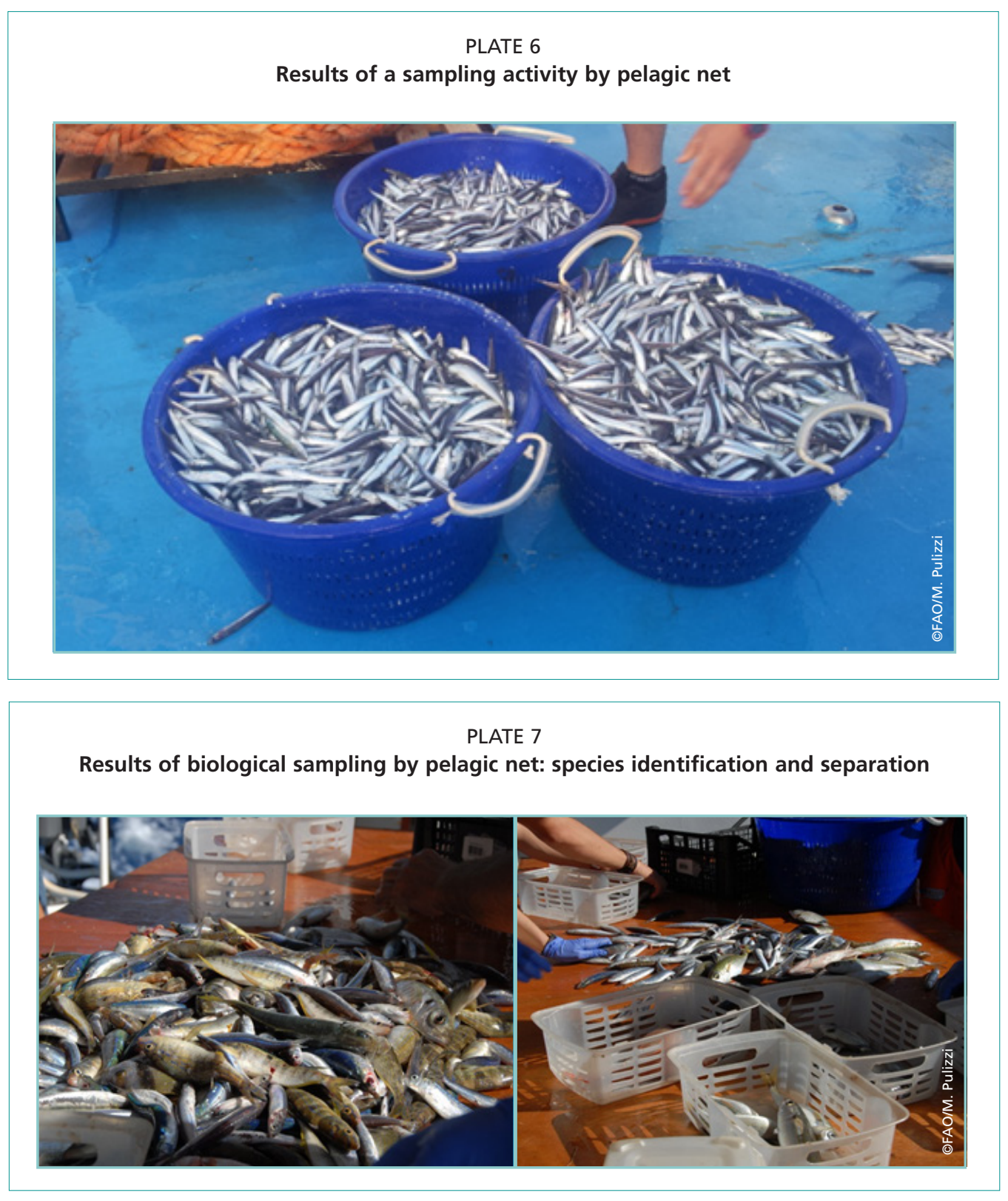

This subsample should be not less than 100 individuals per species. The total length (TL) of each fish should be measured on board immediately, with the tail fully extended to the lower half centimetre. Length data for groups of species can be collected using the forms in Annex 5.

Individual weight $( \pm 0.01 \mathrm{~g})$ should be collected and recorded (Annex 6.1), at least for all pelagic species of group 1 (Annex 2 and Table 4). If it is impossible to determine individual weight, as a possible alternative, the number and total weight of a group of individuals with the same length should be recorded in order to calculate the mean weight of individuals in the length class (Annex 6.2).

Sex is defined following four categories, through macroscopic observation: male $(\mathrm{M})$, female $(\mathrm{F})$, undetermined ( $\mathrm{U}$ - when, after dissection, it was not possible to determine the sex of different specimens with the naked eye), not determined (ND - an individual that has not been examined), and the spawning phases (Annexes 7 and 8). Based on the pelagic acoustic protocol in place (MEDIAS, 2017, 2019), for sardine (Sardina pilchardus) and anchovy (Engraulis encrasicolus) only, 
a six-phase maturity scale, which would permit comparability of data among pelagic surveys, should be used (ICES, 2008; Annex 9) .

Otoliths of the target species can be collected for age determination at a laboratory (Plate 8) and reported in Annex 6.1.

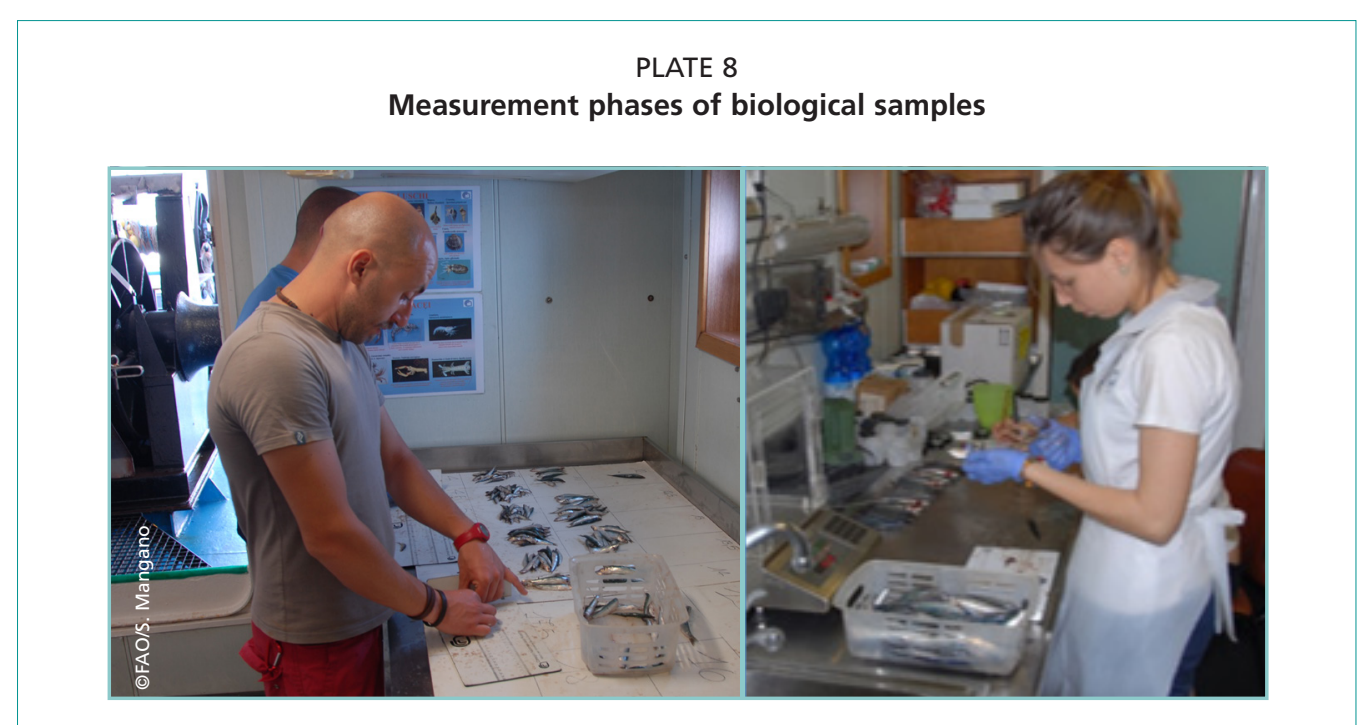

\subsection{OCEANOGRAPHIC DATA}

A multiparametric CTD probe should be used to acquire vertical profiles of the main oceanographic variables (e.g. pressure, temperature, and salinity) in the entire water column (MEDIAS, 2015, 2017). Taking into account the great importance of environmental parameters for small pelagic fish, a minimum of three CTD stations should be collected per transect or a grid of stations with density adequate to describe the oceanography of the surveyed area. The hydrographic parameters temperature and salinity should be measured at each station.

\subsection{DATA REPORTING AND EXCHANGE FORMATS}

The acoustic method for small pelagic fish biomass estimation is structured in two main phases to be performed, respectively, on board the vessel (acoustic data and biological samples collection) and at a ground-based laboratory (post-processing of acoustic data and analysis of biological samples). During the first phase, acoustic data collected both along the survey tracks and during the calibration procedure, should be stored in a specific format (e.g. *.raw or *.hac) in a mass storage unit.

The results of the second phase should be reported in specific tables or maps in terms of nautical area scattering coefficient (NASC) (MacLennan, Fernandes and Dalen, 2002) per EDSU, biomass per EDSU and numbers per EDSU (see Annex 12).

\footnotetext{
Collected maturity data, only for the purpose of the DCRF (GFCM, 2018a), should be submitted and reported with reference to the maturity scales based on DCRF rules and requirements (Recommendation GFCM/41/2017/6) using the conversion table as in Annex 10.
} 
In particular, the following abundance estimates, maps and charts are obtained:

\begin{tabular}{ll}
\hline Abundance indices & - Total fish NASC per EDSU \\
& - NASC per EDSU for each target species \\
& - Biomass per EDSU for each target species \\
& - Numbers per EDSU for each target species \\
& - Biomass/age per length class for each target species \\
\hline Maps and charts & - Point maps of total fish NASC \\
& - Point maps of target species in NASC/mile; biomass/mile \\
- Catch compositions of the fishing hauls, pies charts indicating biomass per species
\end{tabular}

Moreover, total biomass and total abundance (both by age class and by length class) should be estimated.

The minimum length and age data to be collected and reported during the implementation of a pelagic acoustic survey are summarized in Box 1 and Box 2.

\section{BOX 1}

\section{Length data to be reported during a pelagic acoustic survey}

- Country (country codes according to code list of FAO Member States, www.fao.org/ countryprofiles/iso3list/en/)

- Year (year of survey in four-digit integer)

- Start day (starting day of survey in two-digit integer)

- End day (ending day of survey in two-digit integer)

- Start month (starting month of survey in two-digit integer)

- End month (ending month of survey in two-digit integer)

- GSA (area code according to Annex 1)

- Variable (abundance or biomass)

- Species (FAO 3-letter code)

- Sex $($ female $=F$, male $=\mathrm{M}$, undetermined $=\mathrm{U}$, not determined $\mathrm{ND}$; combined $=\mathrm{C}$ )

- Unit (unit of length classes, $\mathrm{mm}=$ millimetre, $\mathrm{cm}=$ centimetre)

- Length classes 0 through 26 (numbers for abundance or tonnes for biomass, precision in thousands $=$ three digits after comma)

Note: See annex 12.1 for complete list of fields.

BOX 2

\section{Age data to be reported during a pelagic acoustic survey}

- Country (country codes according to code list of FAO Member States, www.fao.org/ countryprofiles/iso3list/en/)

- Year (year of survey in four-digit integer)

- Start day (starting day of survey in two-digit integer)

- End day (ending day of survey in two-digit integer)

- Start month (starting month of survey in two-digit integer)

- End month (ending month of survey in two-digit integer)

- GSA (area code according to Annex 1)

- Variable (abundance or biomass)

- Species (FAO three-alpha code)

- Sex $($ female $=F$, male $=M$, undetermined $=U$, not determined $=N D$, combined $=C)$

- Unit (unit of length classes, $\mathrm{mm}=$ millimetre, $\mathrm{cm}=$ centimetre)

- Age group 0 (numbers for abundance or tonnes for biomass, precision in thousands = three digits after comma)

- Age group 1 (numbers for abundance or tonnes for biomass, precision in thousands = three digits after comma)

- Age group 9 plus (numbers for abundance or tonnes for biomass, precision in thousands $=$ three digits after comma)

Note: See Annex 12.2 for complete list of fields. 



\section{DEMERSAL BEAM TRAWL SURVEYS}

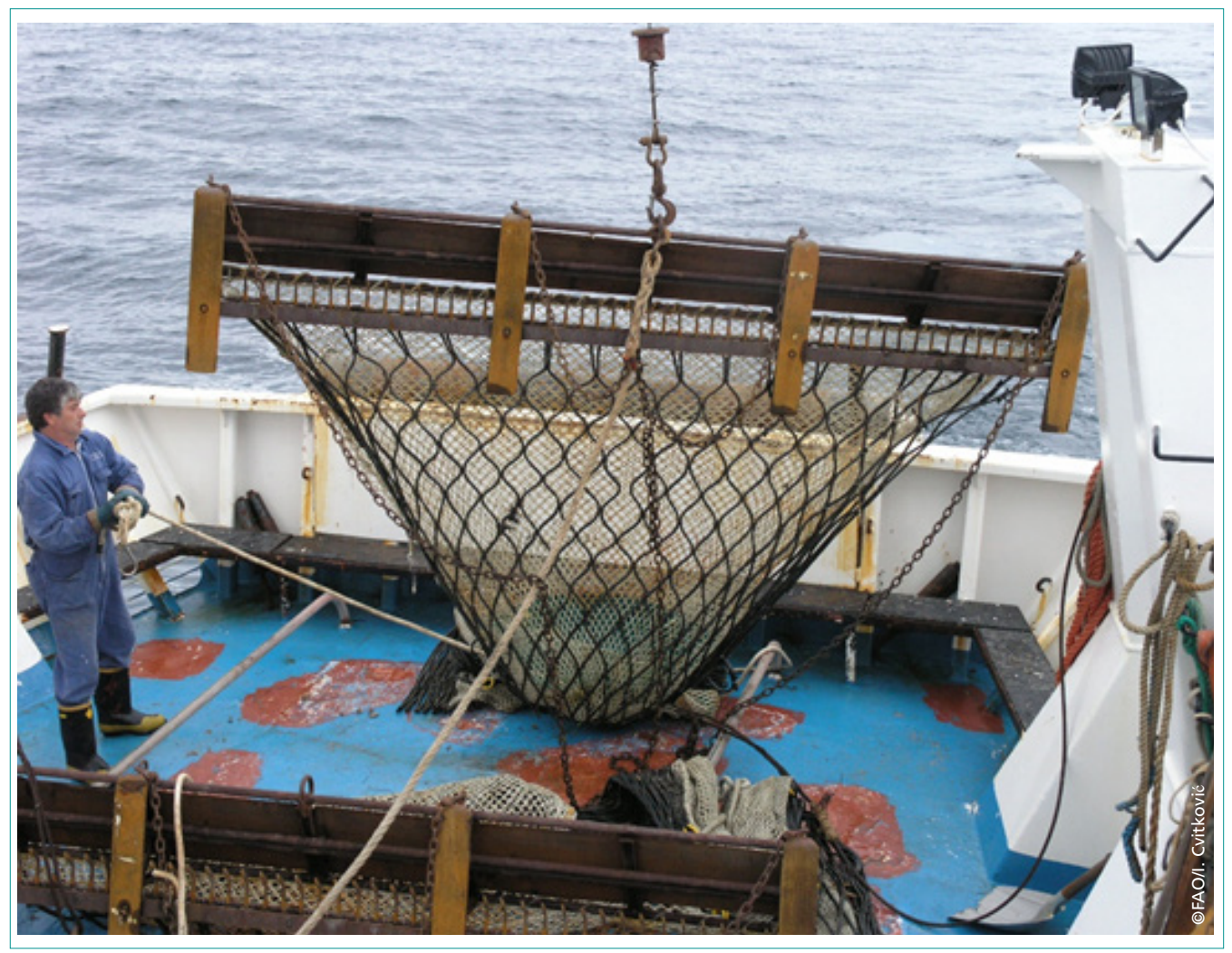

\section{$3.1 \quad$ AlM}

The main aims for carrying out a standard and harmonized BTS are similar to those of a bottom trawl survey (Section 1). The main difference is that a BTS can supply fishery-independent indices and estimates of the age/length structure of target stocks that are not effectively sampled during a bottom trawl survey, such as flatfish, shellfish and other commercially-important benthic organisms.

In particular, in the different GSAs and/or GFCM subregions, a BTS can provide accurate information in terms of relative abundance/biomass, population distribution, demographic structure and biological parameters for target species such as common sole (Solea solea), cuttlefish (Sepia officinalis) and mantis shrimp (Squilla mantis), common in the Mediterranean Sea, but also turbot (Scophthalmus maximus) and Rapana whelk (Rapana venosa) common in the Black Sea.

Also, in coastal areas characterized by shallow waters and flat muddy bottoms, such as the Nile Delta, Iskenderun Bay, the inshore areas of the gulf of Lion and the Thracian Sea, a BTS can be a suitable technique for collecting fishery-independent data for different coastal benthic resources. In addition, a BTS can provide additional data for other demersal stocks already sampled during a standard bottom trawl survey (e.g. red mullet). These data can be functional in integrated approaches (e.g. SS3, a widely used statistical catch-at-age model), characterized by the use of more than one tuning index having a different selection pattern. 
Similarly to standard bottom trawl surveys, a BTS can collect data on epibenthos assemblages as well as on VMEs (e.g. Pennatulacea). However, while in a standard bottom trawl survey, such data usually provide a qualitative indication of benthos assemblages, in a BTS, they can deliver quantitative data of benthos assemblages. Moreover, during the BTS, data on marine litter distribution and abundance can be collected.

Taking into consideration that, to date, the only BTS carried out regularly in the Mediterranean Sea is the SoleMon survey (SoleMon, 2017, 2019), which has been conducted since 2005 in the Adriatic Sea (see Box 3), it is recommended to use the same gear and methodology to have standard approaches and comparable results in other areas of the Mediterranean and Black Sea.

\section{BOX 3}

The SoleMon survey in the northern Adriatic Sea (GSA 17)

The SoleMon survey aims to collect data on distribution and relative abundance, with biological information on commercial fish species in GSA 17, to provide useful data for stock assessment and fishery management. The SoleMon survey programme is currently coordinated at the international level among Italy, Slovenia and Croatia, and since 2009 is harmonized in the framework of the ICES Working Group on Beam Trawl Surveys (WGBEAM). The primary target species is sole, with additional species including cuttlefish, scallop, queen scallops, mantis shrimp, turbot, brill, skates and caramote prawn.

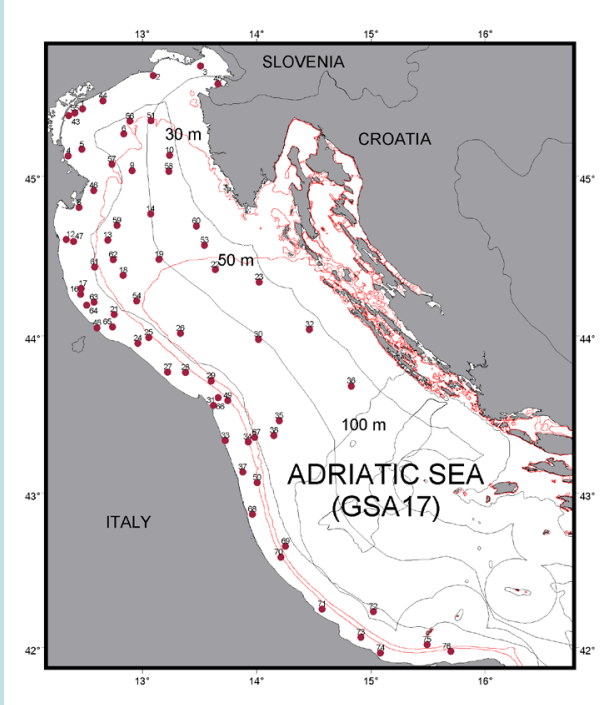

\subsection{VESSEL CHARACTERISTICS}

Taking into account the sampling gear characteristics (Section 3.3) as well as the rigging, a BTS should be carried out with commercial and/or research vessels equipped with an engine of at least $298 \mathrm{~kW}(400 \mathrm{hp})$ to be able to tow the sampling gear with a correct speed. Trawl speed during each fishing operation should be from 4 to 5.5 knots. This recommended speed range is very important to ensure that the gear is always in contact with the seabed. A speed lower than 4 knots can have a negative influence on the penetration depth of a beam trawl into the seafloor. Therefore, the speed is an important factor determining catch efficiency, particularly for buried species, and also depends on the sediment type. It is recommended to monitor and report the speed of the trawl and to use the same speed every year.

During the survey implementation, details of each fishing haul (e.g. latitude, longitude, depth, speed, direction, etc.) should be monitored and reported as in Annex 3.1. Whenever possible, temperature, salinity and other parameters from the surface to the bottom should be sampled. Annex 3.2 can be used to report these data.

\subsection{SAMPLING GEAR}

A beam trawl is a kind of trawl characterized by the mouth, or opening of the net, that is kept open by a beam mounted at each end on guides or skids that travel along the seabed. The trawls should be adapted and made more effective by attaching tickler chains (for sand or mud) or heavy chain matting (for rough, rocky ground), depending on the type of ground being fished. These drag along the seabed in front of the net, 
disturbing the fish in the path of the trawl, causing them to rise from the seabed into the oncoming net. Modern beam trawls range in size from $4 \mathrm{~m}$ to $12 \mathrm{~m}$ (weighing up to 7.5 tonnes in air) beam width, depending on the size and power of the operating vessel.

In implementing this survey in the Mediterranean and the Black Sea, a modified beam trawl called "rapido" should be used (SoleMon, 2017, 2019). This gear, commonly employed in the Adriatic subregion, was appositely designed to work on different types of soft bottoms. It consists of a modified beam trawl (Giovanardi et al., 1998; Hall-Spencer et al., 1999) with a rigid mouth fitted with 46 iron teeth (6-7 cm long) along the lower part. Joined to the iron frame there are four skids and a reinforced rubber diamond-mesh net in the lower part to protect the polyamide net bag (width: $3.59 \mathrm{~m}$; height: 0.25 ; weight: around $225 \mathrm{~kg}$; four $120-\mathrm{mm}$ wide skids). The gear is always in contact with the seabed by an inclined wooden board (width: $3.60 \mathrm{~m}$; length: $0.35 \mathrm{~m}$; thickness: 0.03; weight: around $25 \mathrm{~kg}$ ) fitted to the front of the iron frame, which acts as a spoiler and keeps the skids and the teeth tightly pushed down to the seafloor. The gear is joined to the warp with iron chains (long chain length: $2.10 \mathrm{~m}$, short chain length: $1.00 \mathrm{~m}$ ). A schematic representation of this gear is given in Figure 12 (drawings in Annex 17 schematize with more details all the different components).

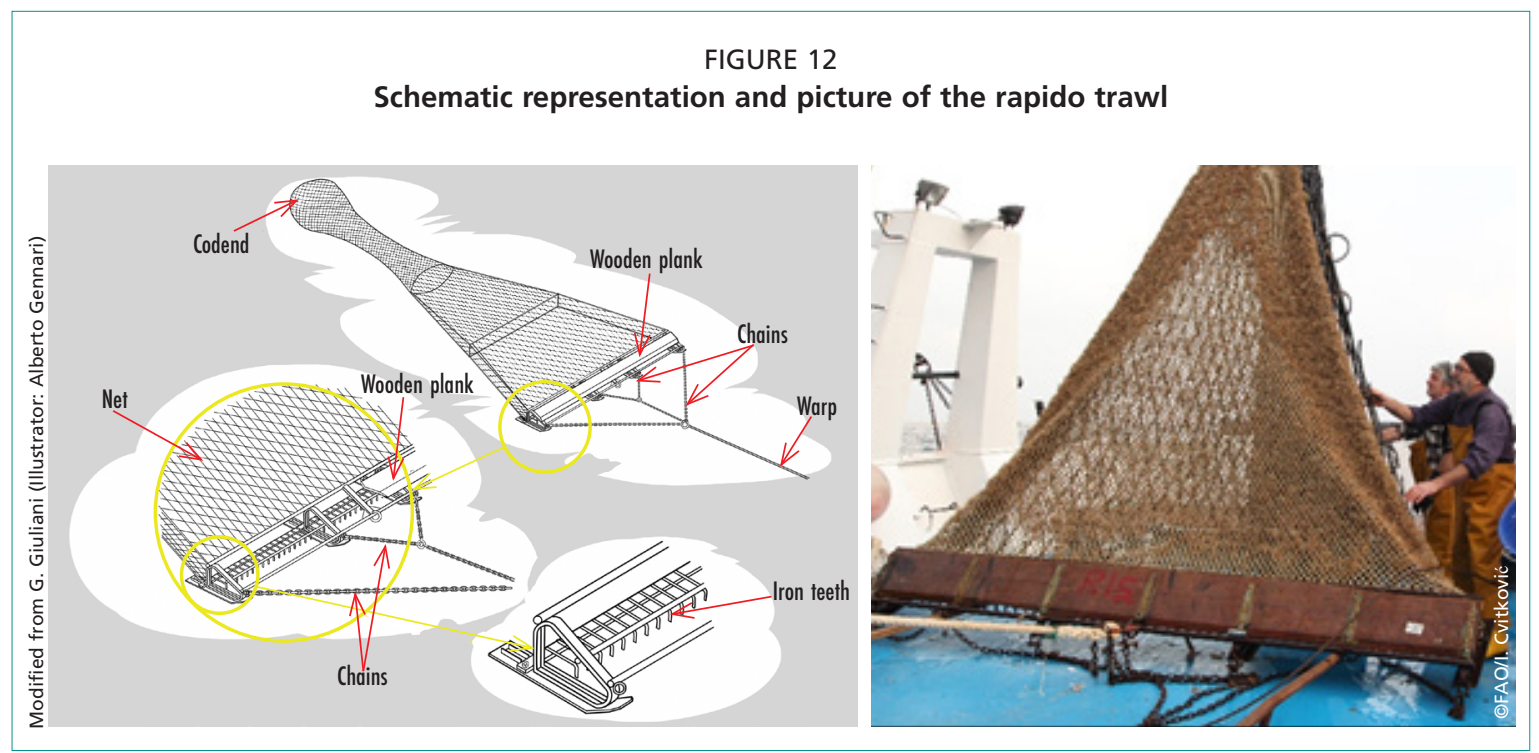

In Figure 13, the mesh sizes are indicated in bar length. The mesh numbers in height correspond to well-finished and joined netting sections; the joining meshes are also shown. The length of the net is around $2.7 \mathrm{~m}$. All fishing hauls should be undertaken using the rapido and the net as specified in the design.

The most important specifications of this gear are as follows:

- It is able to work from 5 to $100 \mathrm{~m}$ depth.

- It has a selectivity as low as possible, so as to have good images of the populations sampled, including recruits.

The mesh size of the codend should be $26 \mathrm{~mm}$ of mesh side (stretch). The nets should be made of good-quality polyamide netting (nylon).

\subsubsection{Rigging}

In implementing this survey, it is advisable that a vessel should be able to tow two fishing gear simultaneously, namely "beam A" on the right side of the vessel and "beam D" on the left side. (Figure 14). The gear positioned on the right side of the vessel should have $15 \mathrm{~m}$ more warp than the other in order to avoid possible interference between the two gear during the fishing haul. 


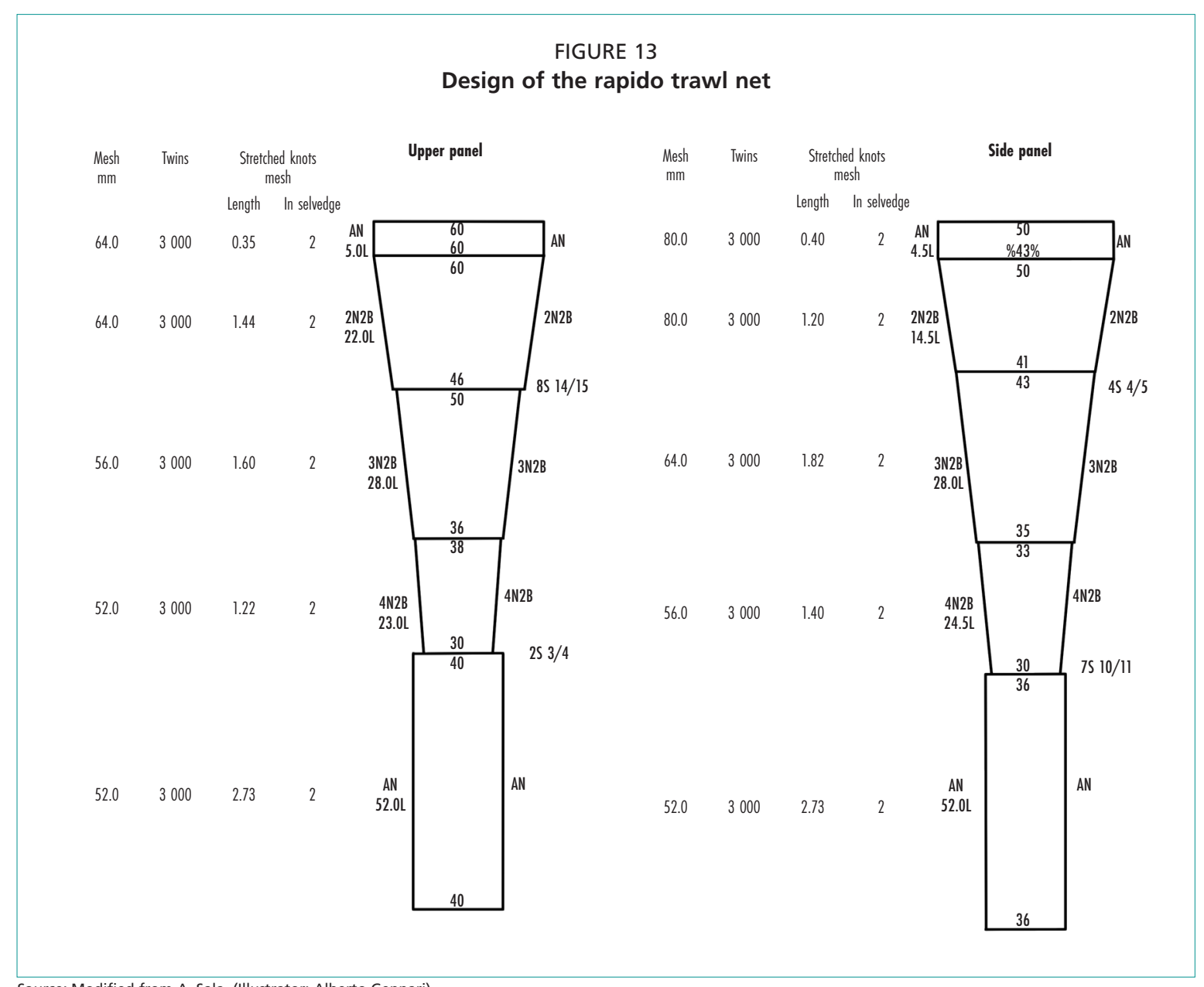

Source: Modified from A. Sala. (Illustrator: Alberto Gennari)

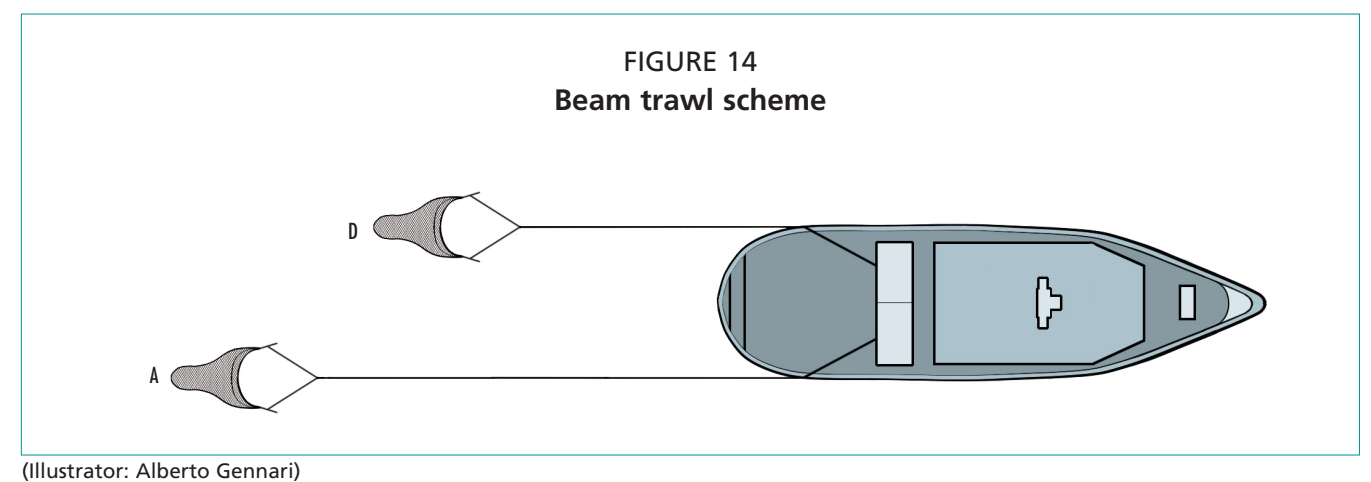

\subsubsection{Warp diameter and length}

Taking the characteristics of the rigging and the gear into account, the warps should have a diameter of 14-16 $\mathrm{mm}$. The length of warps to be shot is determined by the depth. The suggested relationship between depth and warp length is given in Figure 15. Although in certain peculiar circumstances some adaptations can be made to this relationship, it is recommended to respect the depth/warp length ratio as far as possible. Gear should be equipped with a DST (depth, salinity, temperature) recorder device. The use of this device, together with the fixed measures of mouth of the gear, should allow to know exactly the area explored by each gear. 


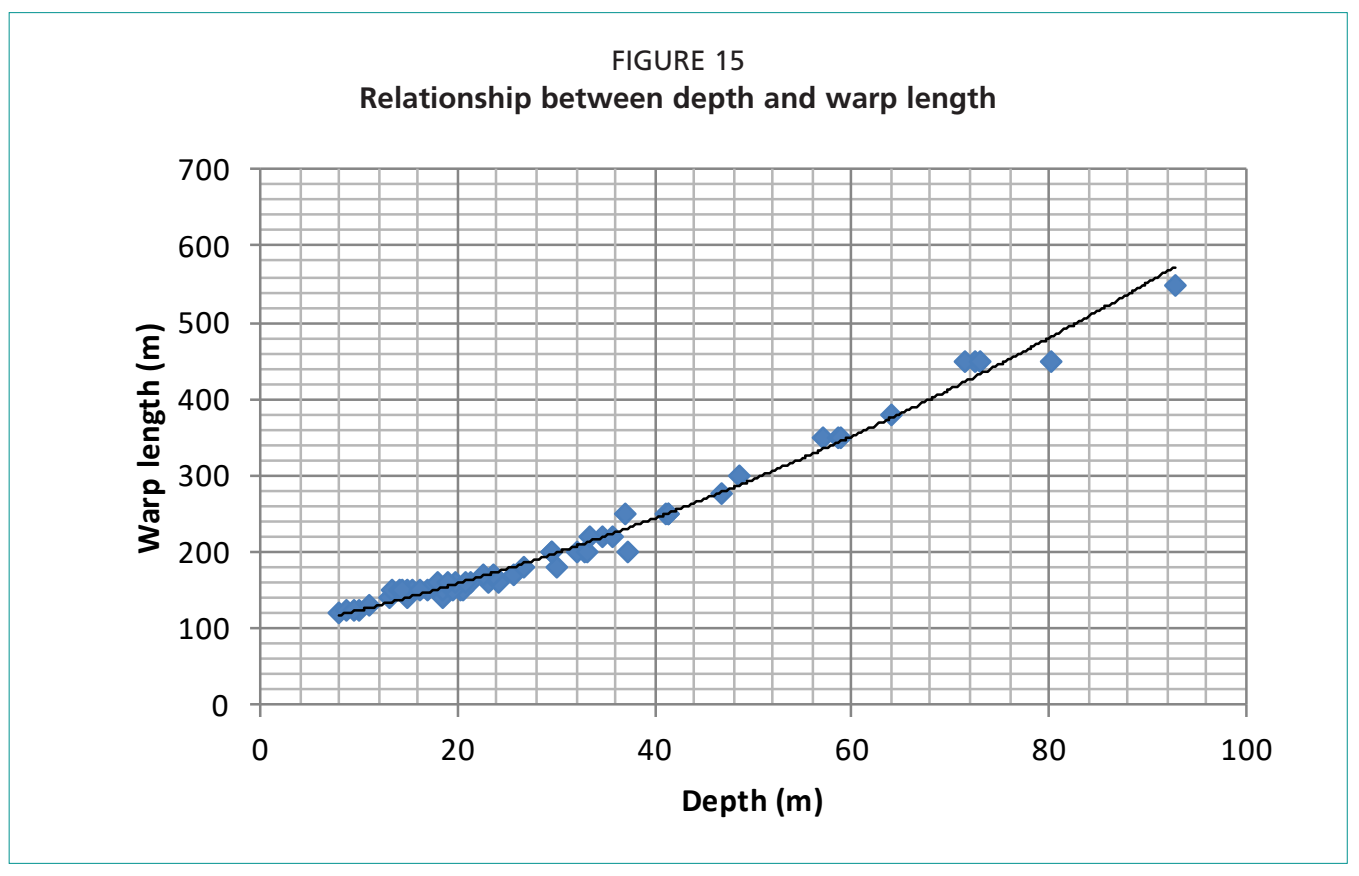

\subsection{SURVEY DESIGN}

Similarly to a standard bottom trawl survey, during a BTS, one of the primary methods for estimating accurate indices reducing the variance of the estimates is to stratify the sampling frame into sets of sampling units with more homogeneous properties (Cochran, 1963). The overall variance is estimated as a weighted average of the withinstratum variances. If the strata have been defined appropriately, the stratified estimate of the variance will be smaller than that obtained from a simple random sample. When a BTS is carried out in the Mediterranean and the Black Sea, the sampling frame can be a GSA or a combination of GSAs according to the stock configuration of the target species, assuming as bathymetric limit the maximum depth beyond which a certain sampling gear (a beam trawl) is no longer efficient in sampling the target species.

For a BTS, a stratified random sampling design should be chosen, because fish and shellfish are seldom uniformly distributed, and in most cases, abundance is related to depth (Sparre and Venema, 1998). Therefore, a stratified random sampling scheme has several advantages over a purely random scheme, also for a BTS:

- sampling is spread out over the whole area of the survey (e.g. GSAs) by assuring the required number of fishing hauls in each stratum (e.g. bathymetric range); and

- sampling rates, in terms of fishing hauls per unit area, can be varied to improve the precision of estimates for some key species, this being an advantage over systematic sampling.

In a BTS, the fishing haul location, depending on the characteristics of each area (see Section 3.4.1), can be randomly selected within identified bathymetric stratum prior to each cruise. Importantly, the rapido trawl is efficient if used only at depths less than $100 \mathrm{~m}$.

\subsubsection{Survey area}

The total area covered by a BTS should be stratified according to depth and geographical criteria, and if known, fish density. Fishing hauls positions should be chosen randomly in a first survey, but may be used as known and clear tow fishing hauls during subsequent surveys, except in the case of particular problems (e.g. area closures for military reasons). Regarding the standard bottom trawl survey as well as the BTS, it is advisable to control the bottom condition to understand if the area is trawlable. 
This control can be carried out using an echo-sounder or information gathered from local fishers (Sparre and Venema, 1998).

For conservation purposes, sensitive habitats (e.g. Posidonia spp. meadows, coralligenous beds, etc.) should be excluded from the sampling scheme and should never be trawled. All these aspects should be considered during the process of allocating fishing hauls to the different depths. In particular, in the case of a BTS, it is advisable to carry out an explorative haul of a few minutes (from 2 to 5 minutes) in order to understand the nature of the substratum in term of granulometry and morphology. Should this explorative haul show a significant amount of rhodolite or phanerogams leaves, it is recommended to move away the fishing haul.

\subsubsection{Depth strata and sampling stations}

Before the survey, the surface area and number of fishing hauls by GSA and for each identified stratum should be identified. In absence of already available information about the density of target species by strata, the fishing hauls should be proportionally distributed over the shelves (from 0 to $100 \mathrm{~m}$ ) according to the surface of each stratum and should follow a depth-stratified sampling scheme with a random drawing of the positions. For a given amount of sampling effort (e.g. 100 fishing hauls), based on several technical constraints (e.g. availability of funds, vessel), a greater degree of precision can be attained by increasing sampling in areas, or strata, of high abundance of target species.

Stratified sampling involves conducting a preliminary survey to identify different strata in the spatial distribution of the target species. These strata could be identified on the basis of information on biology of the target species. On the other hand, systematic pre-surveys could be carried out positioning the fishing hauls on fixed distances that could be considered the lower limit of the distribution pattern of many target species of the survey.

In order to decide on the number of fishing hauls inside each strata that maximize the precision in the estimate of the abundance of a pool of target species, a standard method based on the Neyman equation (Neyman, 1938) can be applied using the data of abundance and variances from the systematic survey to find a mathematical solution to the allocation problem. To reduce or avoid covariance between fishing hauls in adjacent strata, the distance between fishing hauls should be at least 5-10 miles (ICES, 2010).

Similarly to the standard bottom trawl survey, the length of a haul needs to be standardized, because the catchability of target species and sizes often depends on the duration of the haul. Moreover, fishing hauls should be performed at a constant depth. The depth variations during the haul should not exceed \pm 5 percent relative to the initial depth. As far as possible and in respect of the previous constraints, the hauls should be rectilinear. The gear should stay in good contact with the seabed during the entire haul. This can be checked by the depth profile available from the minilog data logger and by observing the skids and teeth wear at the end of the haul.

During a BTS carried out with a rapido trawl, it is recommended to adjust the speed as follow:

- During the shooting of the warps, a relatively high speed (6-6.5 knots) should be maintained.

- The speed should then be reduced (to 3.5-4 knots) just before the rapido touches the sea bottom and is stopped.

- Once the rapido is on the seabed, a speed of 5-5.5 knots should be maintained to allow the gear to be in close contact with the sea bottom; this moment is defined as the real start of the fishing haul. 


\subsubsection{Survey period and timing of fishing operations}

A BTS should be conducted every year during autumn, corresponding to the period of recruitment and/or spawning for most of the identified priority species (see Table 5). Each country, based on the main biological aspects of the selected species (e.g. recruitments and spawning periods), should choose the best month(s) during this period to carry out the survey. This will permit greater comparability of data among areas and GFCM subregions. It is strongly recommended that the sampling period of the survey be consistent year-to-year to reduce the time-of-the-survey effect on the time series (ICES, 2012).

It is also recommended to conduct fishing haul operations during daylight hours. The daylight period is defined as the time between 30 minutes after sunrise and 30 minutes before sunset. A fishing haul consists of 30 minutes of trawling two gear simultaneously during daytime, starting when the gear settles on the bottom and ending when hauling commences. Depending on the circumstances (e.g. great amount of shells and debris), a shorter period is allowed. Should the fishing haul be stopped before completion of the standard duration, it can be considered valid if at least two-thirds of the time or of the distance have been successfully attained.

\subsection{HANDLING OF THE CATCH}

The catch of the two gear towed simultaneously should be analysed separately for "beam A" and "beam D". The entire catch of each gear (Plate 9) should be sorted and weighted for all bony fish, rays, sharks, cephalopods and commercially important shellfish and crustaceans' species (Annex 4). For the whole catch (or a subsample) of the epibenthic/benthic species and debris (see Section 3.5.2), the weight and the total number should be recorded (fresh on board or in the lab) for each species identified to the lowest taxonomic level possible.

Length measurements (Annex 5), weight, otolith (Annex 6), sex and maturity (Annex 7), should be collected and reported for the main target species following the same approach defined for the bottom trawl survey (see also Section 1.5.2).

In Table 5, the priority species (Annex 2) for which a BTS can provide both primary and/or additional data for tuning indices are specified by subregion.

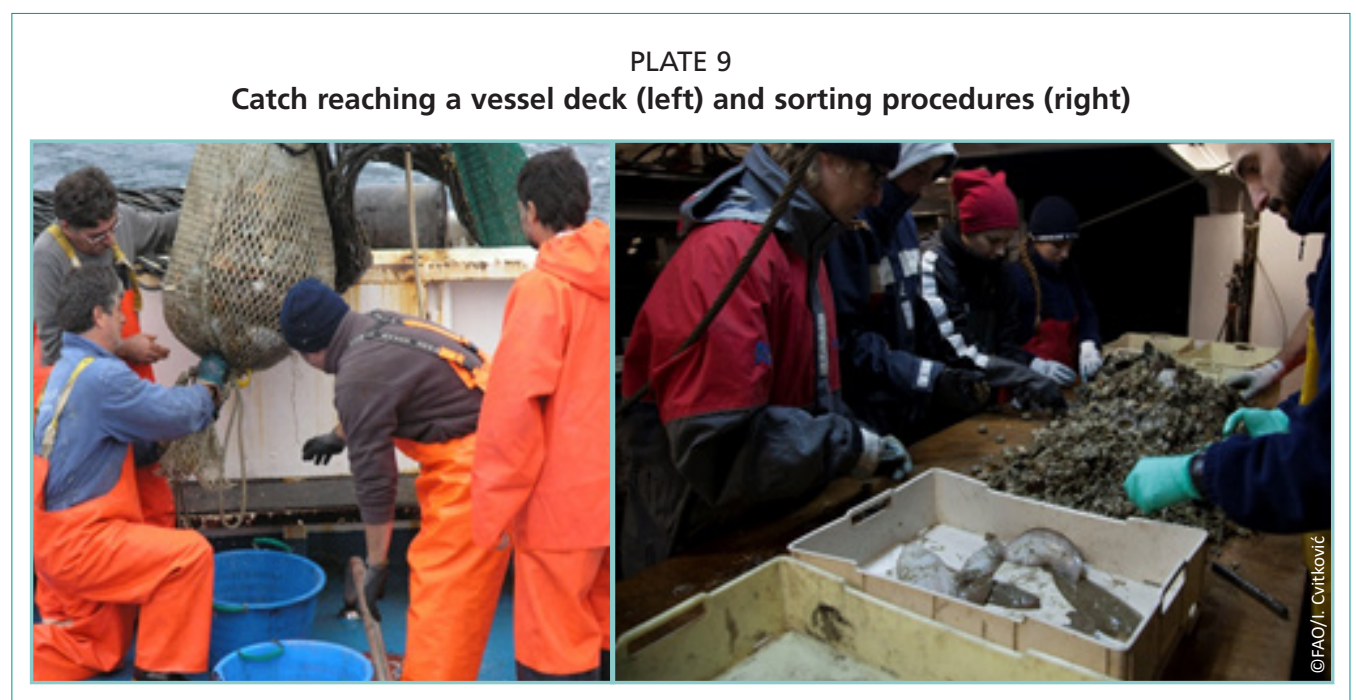


TABLE 5

Priority species of potential interest for which a BTS could provide primary and/or additional data for tuning indices, by GFCM subregion

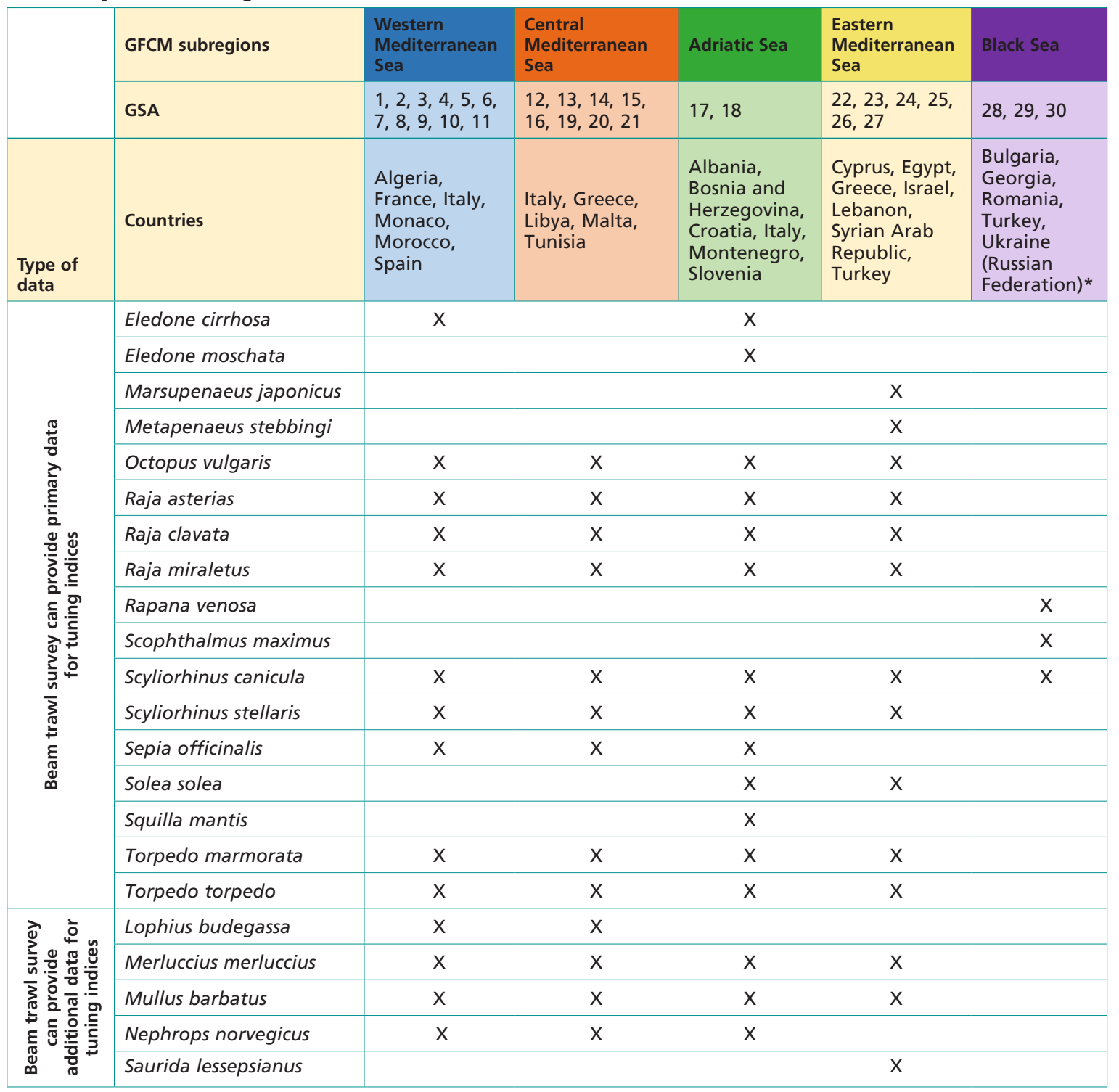

\subsubsection{Biological parameters}

\subsection{1a Length measurements}

For fish (both bony fish and elasmobranches), the length is always the total length, the tail being extended following its longer dimension (see also Section 1.5.2a). The measurement unit (in $\mathrm{cm}$ ) should be reported to the lower half centimetre (e.g. $13.4=13 \mathrm{~cm} ; 16.8=16.5 \mathrm{~cm}$ ).

For crustaceans, the length is measured in terms of cephalo-thoracic (carapace) length at the lowest millimetre $(\mathrm{mm})$. For cephalopods, the length is the mantle length at the half centimetre $(\mathrm{cm})$. For commercially important bivalves, the shell length at the lowest millimetre is recorded (Section 1.5.2a).

Subsampling by species may occur for the length measurements when the numbers are extremely high. Length data should be collected and reported as in Annex 5 at least for the main priority species, by GFCM subregion (Annex 2). 


\subsection{1b Sex and maturity}

Also for BTS, sex is defined through macroscopic observation according to four categories: male $(\mathrm{M})$, female $(\mathrm{F})$, undetermined ( $\mathrm{U}$ - when, after dissection, it was not possible to determine the sex of different specimens with the naked eye), and not determined (ND - an individual that has not been examined). Sex and maturity data should be collected and reported (Annex 7) for the main priority species.

When carrying out a demersal beam trawl, maturity scales designed for scientific trawl surveys with similar data (e.g. SOLEMON data) in other contexts should be used (e.g. MEDITS, 2017; see Annex 8) ${ }^{5}$. Using common maturity scales would simplify data sharing and data quality checks.

\subsection{1c Otolith, weight at the individual level}

Similar to demersal trawl surveys (see Section 1.5.2d), otoliths should be collected at least for the targets species of fish.

When otoliths are removed, the length, the individual weight, together with the sex and maturity stage of the sampled specimen, should be collected (Annex 6.1). For the target fish species, it is suggested to collect a minimum of ten otoliths per identified length class in each fishing haul.

\subsubsection{Analysis of epibenthos, benthos, debris and marine litter}

Sorting, counting and weighting epibenthic and benthic species (see Section 4.1), together with debris (i.e. shells, rocks, etc.) and marine litter items (see Section 4.3), should be carried out (whenever possible) directly on board on fresh material. Photos of epibenthic/benthic species, debris fraction and marine litter should be systematically taken at each fishing haul (see Annexes 15 and 16).

The subsampling should be carried out as follows:

- if the catch of epibenthic/benthic species and debris fraction in one rapido is around or less than $30 \mathrm{~kg}$, all the species and debris items should be sorted directly without subsampling.

- If the catch of epibenthic/benthic species and debris fraction in one rapido is more than $30 \mathrm{~kg}$, a subsample varying from 50 to 5 percent of the catches should be taken and sorted directly following the rules in Table 6.

TABLE 6

Subsampling of epibenthic and benthic species, and debris fraction

\begin{tabular}{|c|c|}
\hline $\begin{array}{l}\text { Weight of the portion of epibenthic/benthic species } \\
\text { and debris fraction }(\mathbf{k g})\end{array}$ & Percentage to be sampled \\
\hline$\leq 30$ & 100 \\
\hline$>30 \geq 60$ & 50 \\
\hline$>60 \geq 500$ & 20 \\
\hline$>500 \geq 1500$ & 10 \\
\hline$>1500$ & 5 \\
\hline
\end{tabular}

All the items of marine litter should be collected from one randomly chosen rapido and analysed. The fraction of epibenthic/benthic species and debris sorted for the rapido randomly chosen are assumed to correspond to the rapido that hasn't been analysed. The quantitative amount of the species assumed for the rapido not analysed are standardized on the basis of its overall catch weight, calculating the raising factor (RF) as follows:

R.F.= (Sum of the weight of epibenthic-benthic species and debris from Beam A and Beam D)

(Weight of the sample of epibenthic-benthic species and debris)

5 Collected maturity data, only for the purpose of the DCRF (GFCM, 2018a), should be submitted and reported with reference to the maturity scales based on DCRF rules and requirements (Recommendation GFCM/41/2017/6). 


\subsubsection{Other parameters}

During a single fishing haul, depth temperature throughout the tow should be recorded and monitored. A wide range of instruments can be been used to measure temperature and salinity.

At the end of a beam trawl fishing haul, a vertical cast with CTD should be made for temperature, salinity and turbidity.

\subsection{DATA REPORTING AND EXCHANGE FORMATS}

Similarly to demersal trawl surveys, BTS outcomes should satisfy different data requirements within the GFCM:

- Useful information in compliance with existing GFCM recommendations should be reported to the GFCM by its CPCs.

- Information supporting stock assessment should be reported to the WGSAs through stock assessment forms.

- Other relevant information for regional analysis should be examined in dedicated expert groups.

Standard formats are defined for the storage and exchange of data produced by a BTS. Once collected, the basic information on fishing hauls, catch and biological data should be reported using the templates ${ }^{6}$ shown in Annex 11 (see also Section 1.6)

\footnotetext{
${ }^{6}$ All the templates are available for consultation and download in electronic format at: http://www.fao.org/gfcm/data/en/
} 


\section{ECOSYSTEM DATA}

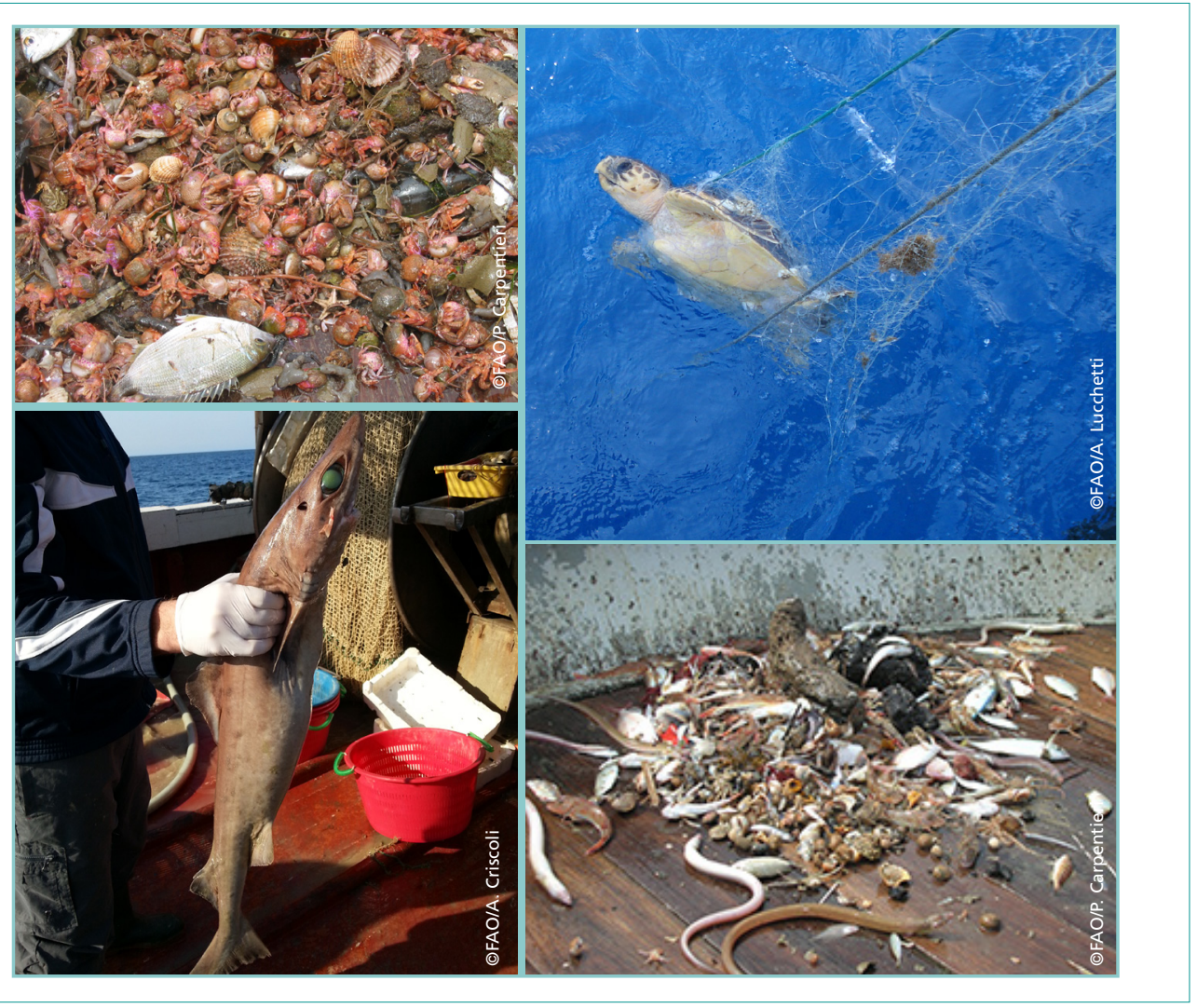

\subsection{MACROBENTHOS}

Fishing is the most widespread human activity exploiting the marine environment and has a direct impact not only on target species, but also on the entire marine community, including benthic organisms (plate 10) (GFCM, 2018b; FAO 2019a, 2019b). The importance of benthic habitats to ecological processes and as providers of key ecosystem services is unquestionable. In particular, macrobenthos or megabenthos $(>2 \mathrm{~cm})$, generally defined as a group of marine invertebrate organisms that live in (infauna) or on (epifauna) the sediment, due to their direct dependency on the sediment, become a valuable part of the ecosystem and are frequently used as bioindicators in ecological assessment (Pinto et al., 2009).

Species distribution, abundance and diversity of benthic macroinvertebrate fauna as well as their relationship to environmental conditions are important in understanding the structure and functions of diverse ecosystems. Macrobenthos form the key element of the food web and serve as primary food source for fish and other higher organisms, also playing a major role in the maintenance, well-being and dynamics of the ecosystem.

Therefore, the collection of data through scientific surveys, such as surveys on the presence and abundance of different macrobenthic species, can provide a unique opportunity to increase knowledge of benthic assemblages and to produce basic information on their distribution within the Mediterranean and Black Sea region.

For the purpose of these guidelines, macrobenthos are considered as all organisms visible to the eye without the aid of a microscope and pertaining to major taxonomic phylum: Porifera (e.g. sponges), Cnidaria (e.g. corals), Briozoa, Echinodermata (e.g. sea stars, sea urchins, sea cucumbers), Crustacea, Mollusca (e.g. bivalves and gastropods), Annelida (e.g. polychaetes), Tunicata (e.g. ascidians) and others. 


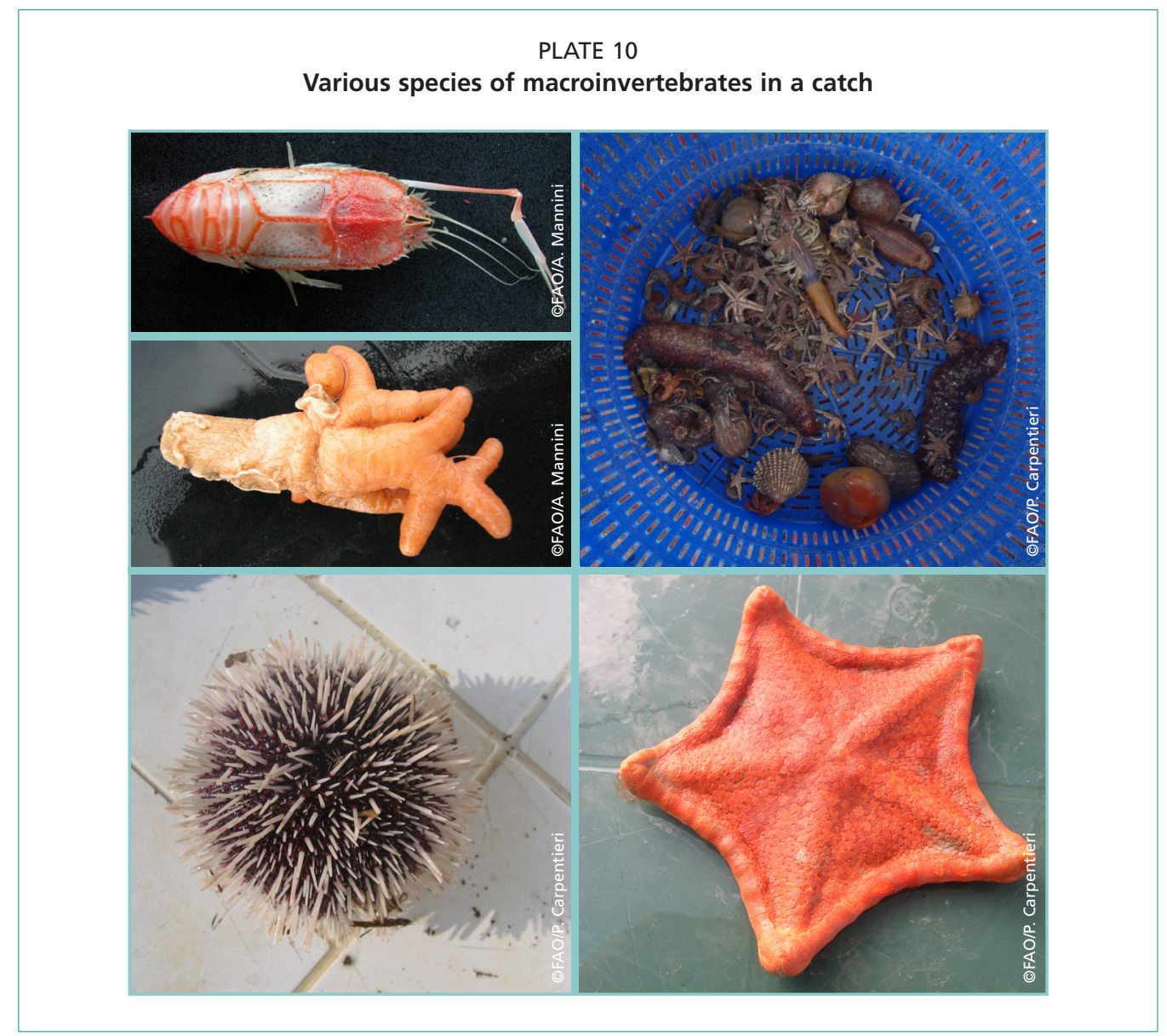

Ideally, macrobenthic individuals should be identified to the minimum taxonomic level, and species is obviously the basic taxonomic level to which to refer. However, since many species pertaining to the macrobenthos groups are difficult to identify (e.g. due a scarcity of taxonomic expertise on board), aggregation of species to higher taxonomic levels (e.g. family or genus) and/or their assignment to morphological groups according to their growth form (e.g. massive, tubular, globular, arborescent, stalked, fan-shaped, lollipop-shaped, cup-shaped, among others - see FAO, 2017a; 2017b) may at times be unavoidable.

In some cases, for correct identification of the species, biological samples should be collected and brought to the laboratory and/or photographic documentation should be made. Coupled with photographic documentation, it is also highly recommended to report on the colour, consistency (e.g. hard, soft, and cartilaginous) and form of benthic species. A minimum set of parameters, such as the total number of individuals caught per fishing haul and total weight (see Annex 16), should be always reported.

Furthermore, owing to the difficulty of collecting information for all macrobenthic species, attention should focus mainly on vulnerable benthic species that may form VMEs as defined by FAO (FAO, 2009; FAO, 2017a, 2017b; GFCM, 2018b, and 2019a). VMEs are characterized by slow resistance and resilience from environmental short-term or chronic disturbance. They are easily disturbed and very slow to recover, or may never recover from such disturbance. VMEs are therefore highly susceptible to the impact of bottom fishing gear (i.e. significant adverse impact of fisheries) (FAO, 2009). Among VME indicator taxa, corals (phylum Cnidaria) and sponges (phylum Porifera) are known to be the main habitat-forming structures, often with numerous species living within or around their body structures.

The GFCM defined a series of VME indicators such as features, habitats and taxa for the Mediterranean Sea (Box 4), which, whenever possible, should be recorded and reported in Annex 16. 
BOX 4

Mediterranean VME indicator: features (a), habitats (b) and taxa (c)

The following features potentially support VMEs:

(a) Mediterranean VME indicator features

- Seamounts and volcanic ridges

- Canyons and trenches

- Steep slopes

- Submarine reliefs (slumped blocks, ridges, cobble fields, etc.)

- Cold seeps (pockmarks, mud volcanoes, reducing sediment, anoxic pools, methanogenetic hard bottoms)

- Hydrothermal vents

(b) Mediterranean VME indicator habitats

The following habitats potentially support VMEs:

- Cold-water coral reefs

- Coral gardens

- Hard-bottom coral garden

- Soft-bottom coral gardens

- Sea pen fields

- Deep-sea sponge aggregations

- "Ostur" sponge aggregations

- Hard-bottom sponge gardens

- Glass sponge communities

- Soft-bottom sponge gardens

- Tube-dwelling anemone patches

- Crinoid fields

- Oyster reefs and other giant bivalves

- Seep and vent communities

- Other dense emergent fauna

(c) Mediterranean VME indicator taxa

$\begin{array}{lll}\text { Phylum } & \text { Class } & \text { Subclass (Order) } \\ \text { Cnidaria } & \text { Anthozoa } & \text { Hexacorallia (Antipatharia, Scleractinia) } \\ & & \text { Octocorallia (Alcyonacea, Pennatulacea) } \\ & \text { Ceriantharia } \\ & \text { Hydrozoa } & \text { Hydroidolina }\end{array}$

Porifera (sponges) Demospongiae

Hexactinellida Amphidiscophora

Hexasterophora

\begin{tabular}{lll}
\hline Bryozoa & $\begin{array}{l}\text { Gymnolaemata } \\
\text { Stenolaemata }\end{array}$ & \\
\hline Echinodermata & Crinoidea & Articulata \\
\hline Mollusca & Bivalvia & $\begin{array}{l}\text { Gryphaeidae (Neopycnodonte cochlear, N. zibrowii) } \\
\text { Heterodonta* (Lucinoida) (e.g. Lucinoma kazani) } \\
\text { Pteriomorphia* (Mytiloida) (e.g. Idas modiolaeformis) }\end{array}$ \\
\hline Annelida* & Polychaeta & $\begin{array}{l}\text { Sedentaria (Canalipalpata) (e.g. Lamellibrachia } \\
\text { anaximandri, Siboglinum spp.) }\end{array}$ \\
\hline Arthropoda* & Malacostraca & Eumalacostraca (Amphipoda) (e.g. Haploops spp.)
\end{tabular}

*only chemosynthetic species that indicate the presence. 
It is important to underline that the presence of individuals of vulnerable benthic species does not necessarily imply the occurrence of a VME, but specific communities, habitats and seabottom features may display characteristics consistent with the possible occurrence of VMEs.

Once collected, all data on macrobenthic species could serve to produce basic information for different ecosystems in terms of species richness (i.e. number of species), abundance (the counts of individuals for every species) and biomass (i.e. weight).

\subsection{VULNERABLE SPECIES}

The incidental capture or bycatch of vulnerable and protected species (e.g. marine mammals, seabirds, sea turtles, sharks and rays, see Annex 13) has become an increasingly important aspect of fisheries management (FAO, 2019b). Limited or nonexistent information from Mediterranean and Black Sea countries regarding bycatch rates for vulnerable species makes it impossible now to assess the likely conservation threat posed by total bycatch levels (FAO, 2016; 2018; GFCM, 2018a; FAO, 2019b). Moreover, the limited data available do not necessarily allow for accurate and realistic assessments of populations and of the impacts of incidental catch on them. More data collection and analyses will be required before it will be possible to produce robust total bycatch estimates for vulnerable species.

Therefore, when carrying out scientific surveys, it is important to collect a minimum set of data (e.g. number of individuals for each vulnerable species; Box 5) that could represent additional/alternative sources of information to provide guidance for any possible revision of incidental catches monitoring programmes. Data should be reported by GSA and by species group and/or family if the detailed information by species is not available (e.g. when an individual could not be identified at the species or genus level, as in the case of recording seabirds, which include a large number of possible species). It is also important to report the total number of individuals caught and whether they have been released alive, dead or in unknown status. When an individual is caught alive, the main goal is to facilitate a prompt release of the specimen through an appropriate handling (FAO and ACCOBAMS, 2018a, 2018b, 2018c, 2018d).

\section{BOX 5 \\ Minimum set of data to be collected regarding the incidental catch of vulnerable species}

- Type of scientific survey

- Fishing gear

- Group of vulnerable species

- Family

- Species (identified as far as possible, or accompanied by photographs if identification is difficult)

- Total number of individuals caught

- Total weight of individuals caught

- Condition at capture and condition at release:

- Number of individuals released alive

- Number of dead individuals

- Number of individuals released in unknown status

All the available information on vulnerable species should be collected and reported using the template ${ }^{7}$ in Annex 14.

All the templates are available for consultation and download in electronic format at: http://www.fao. org/gfcm/data/en/ 


\subsection{MARINE LITTER}

Litter in the marine environment (Plate 11) not only has negative environmental effects, but can also have negative economic and social impacts on fisheries (UNEP/ MAP, 2015). So far, data on marine litter have been inconsistent and geographically restricted to some areas in the Mediterranean and the Black Sea, which explains why the understanding of these impacts is still limited. A standardized data collection protocol of marine litter data started within the framework of the MEDITS scientific survey (Fiorentino et al., 2013), allowing to produce over the years a first mapping of marine litter on trawling fishing grounds (Spedicato et al., 2019). Standardized research data for statistical purposes are still needed regarding the problem of litter in the whole region, and also in this case, bottom trawl and beam trawl surveys could be an important source of information on occurrence of litter on the sea bottoms.

During each survey it would be important to give a rough estimation of the quantity (weight) and quality (type) of any macro-litter material brought up by fishing operations (e.g. plastics, wood, metals, glass, rubber, clothing, fishing gear, petrochemicals). An indicative list of relevant data to be provided is reported in Annex 15. Registration of number and weight of items by categories and by subcategory is highly recommendable.

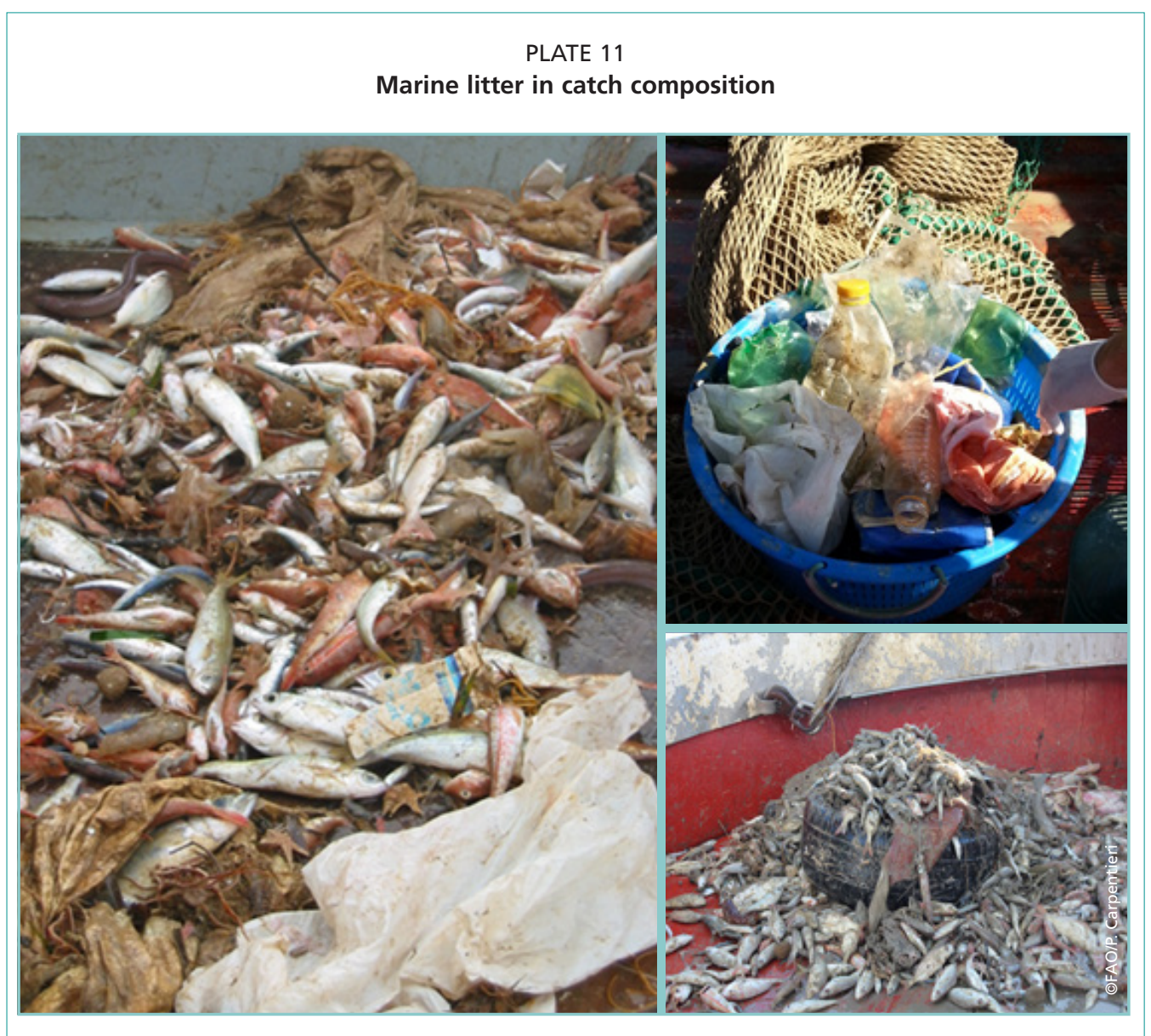

\subsection{NON-INDIGENOUS SPECIES}

In recent decades, non-indigenous species (i.e. any species introduced, either intentionally or unintentionally, outside its natural past or present distribution, also known as exotic or alien species) have been frequently caught by commercial fishing gear in different areas, accounting for a large share of the catch in some cases. In light of this rapid increase, there is a need to collect information in order to measure their impacts on fisheries and ecosystems. Scientific surveys could therefore 
offer an opportunity to collect important and standardized data regarding not only the distribution of nonindigenous species as well as their quantitative and qualitative impacts, but also some biological information (e.g. length, weight, sex and maturity). All of this information, once collected, could contribute to an effective management strategy. When performing any kind of scientific survey, it is strongly encouraged to collect and report biological data on non-indigenous species, using the standard templates already provided (Annexes 5, 6 and 7). 


\section{DATA POLICY}

Data from national scientific surveys should remain the property of the country executing the survey, and data and information transmitted by countries should be treated by the GFCM Secretariat in accordance with all necessary measures to comply with GFCM security and confidentiality provisions. People carrying out the work on board should not disclose any information without the permission of the flag country.

Each country will be responsible for the quality and completeness of the data. Collected data should be submitted by countries every year following the DCRF provisions (GFCM, 2018a) and requirements.

Data put at the disposal of dedicated expert groups will be treated in the same manner as data used by different WGSAs: all participants should have access to the data needed to address the objectives of the meeting.

Through its Secretariat, the GFCM will define and maintain high levels of protection for the data transmitted by countries complying with GFCM data submission requirements, as endorsed by the Commission. The use of shared data outside the framework of the GFCM or for purposes other than the agreed objectives should follow the existing GFCM data confidentiality rules. 



\section{REFERENCES}

AdriaMed. 2011. Report of the Technical meeting on SoleMon survey activities, May 2011. GCP/RER/010/ITA/SR-01. AdriaMed Scientific Reports N. 01. Rome, FAO AdriaMed. $21 \mathrm{pp}$.

Bertrand, J., Gil de Sola, L., Papaconstantinou, C., Relini, G. \& Souplet, A. 1997. An international bottom trawl survey in the Mediterranean: the MEDITS programme. Paper presented at the 1997 ICES Annual Science Conference. Baltimore, United States.

Bertrand, J., Gil de Sola, L., Papaconstantinou, C., Relini, G. \& Souplet, A. 2002. The general specifications of MEDITS surveys. Scientia Marina, 66(2): 9-17.

Bradai, M.N., Saidi, B. \& Enajjar, S. 2012. Elasmobranchs of the Mediterranean and Black Sea: status, ecology and biology. Bibliographic analysis. Studies and Reviews. No. 91. Rome, FAO. 103 pp.

Carbonara, P. \& Follesa, M.C., eds. 2019. Handbook on fish age determination: a Mediterranean experience. Studies and Reviews. No. 98. Rome, FAO. 192 pp.

Cochran, W.G. 1963. Sampling Techniques. Wiley, New York.

COISPA Tecnologia \& Ricerca 2020. MeditsWeb [online]. Bari, Italy. [cited 21 February 2020]. https://www.coispa.it/docs/MeditsWeb/MeditsWeb.zip

Demer, D.A., Berger, L., Bernasconi, M., Bethke, E., Boswell, K., Chu, D., Domokos, R., Dunford, A., Fässler, S., Gauthier, S., Hufnagle, L.T., Jech, J.M., Bouffant, N., Lebourges-Dhaussy, A., Lurton, X., Macaulay, G.J., Perrot, Y., Ryan, T., ParkerStetter, S., Stienessen, S., Weber, T. \& Williamson, N. 2015. Calibration of acoustic instruments. ICES Cooperative Research Report No. 326. Copenhagen.. 133 pp.

Draštík, V., Kubečk, J., Čech, M., Frouzová, J., Říha, M., Jůza, T., Tušer, M., Jarolím, O., Prchalová, M., Peterka, J., Vašek, V., Kratochvíl, M., Matěna, J. \& Mrkvička, T. 2009. Hydroacoustic estimates of fish stocks in temperate reservoirs: day or night surveys? Aquatic Living Resources, 22: 69-77.

Engås, A., Ona, E. \& Ramberg, K. 2001. In situ determination of bottom trawl ground gear contact. ICES CM 2001/Q:07. 20 pp.

FAO. 2009. International Guidelines for the Management of Deep-sea Fisheries in the High Seas. Rome. 73 pp.

FAO. 2016. The state of Mediterranean and Black Sea fisheries. General Fisheries Commission for the Mediterranean. Rome. 134 pp.

FAO. 2017a. Poster: Deep-Sea Sponges of the Mediterranean Sea. (available at http://www. fao. org/3/a-i6945e.pdf).

FAO. 2017b. Poster: Deep-Sea Corals of the Mediterranean Sea. (available at http://www. fao.org/3/a-i7256e.pdf)

FAO. 2018. The State of Mediterranean and Black Sea Fisheries. General Fisheries Commission for the Mediterranean. Rome. $172 \mathrm{pp}$.

FAO. 2019a. Monitoring discards in Mediterranean and Black Sea fisheries: Methodology for data collection. FAO Fisheries and Aquaculture Technical Paper No. 639. Rome. 96 pp.

FAO. 2019b. Monitoring the incidental catch of vulnerable species in Mediterranean and Black Sea fisheries: Methodology for data collection. FAO Fisheries and Aquaculture Technical Paper No. 640. Rome, FAO. 106 pp.

FAO \& ACCOBAMS. 2018a. Good practice guide for the handling of cetaceans caught incidentally in Mediterranean fisheries. Rome, Italy. (available at http://www.fao.org/ publications/card/en/c/CA0015EN) 
FAO \& ACCOBAMS. 2018b. Good practice guide for the handling of sea turtles canght incidentally in Mediterranean fisheries. Rome, Italy. (available at http://www.fao.org/ publications/card/en/c/I8951EN)

FAO \& ACCOBAMS. 2018c. Good practice guide for the handling of sharks and rays caught incidentally in Mediterranean pelagic longline fisheries. Rome, Italy. (available at http://www.fao.org/documents/card/en/c/I9152EN)

FAO \& ACCOBAMS. 2018d. Good practice guide for the handling of seabirds canght incidentally in Mediterranean pelagic longline fisheries. Rome, Italy. (available at http:// www.fao.org/publications/card/en/c/I8937EN)

Fiorentini, L. \& Dremière, P.Y. 1996. Efficacy and selectivity of the trawl used for the MEDITS project. IRPEM interim report. Contract IRPEM-EC, Study 95/29. 17 pp.

Fiorentini, L., Dremière, P.Y., Leonori, I., Sala, A. \& Palumbo, V. 1999. Efficiency of the bottom trawl used for the Mediterranean international trawl survey (MEDITS). Aquatic Living Resources, 12(3): 187-205.

Fiorentino, F., Lefkaditou, E., Jadaud, A., Carbonara, P., Lembo, G. \& Galgani, F. 2013. Protocol for litter data collection during the MEDITS trawl surveys. Rapport Commission International pour l'exploration scientifique de la Mer Méditerranée (CIESM). No. 40. Monaco. 305 pp.

Follesa, M.C. \& Carbonara, P., eds. 2019. Atlas of the maturity stages of Mediterranean fishery resources. Studies and Reviews. General Fisheries Commission for the Mediterranean. No. 99. Rome, FAO. 268 pp.

Foote, K.G., Knudsen, H.P., Vestnes, G., MacLennan, D.N. \& Simmonds, E.J. 1987. Calibration of acoustic instruments for fish density estimation: a practical guide. ICES Cooperative Research Report No. 144. Copenhagen. 82 pp.

GFCM. 2007. Report of the Workshop on Trawl Survey Based Monitoring Fishery System in the Mediterranean, Rome, Italy, 26-28 March 2007. Rome, FAO. 70 pp.

GFCM. 2009. Resolution GFCM/33/2009/2 on the establishment of geographical subareas in the GFCM area of application, amending Resolution GFCM/31/2007/2. http://www. fao.org/gfcm/decisions/en/

GFCM. 2016. Brainstorming meeting on the GFCM BlackSea4Fish project, including a session on scientific surveys at sea, Burgas, Bulgaria, 14 November 2016. Rome, FAO. $22 \mathrm{pp}$.

GFCM. 2017a. Report of the nineteenth session of the Scientific Advisory Committee on Fisheries, Ljubljana, Slovenia, 16-19 May 2017. Rome, FAO. 184 pp.

GFCM. 2017b. Working Group on the Black Sea (WGBS). Report of the sixth meeting, Constanta, Romania, 15-16 June 2017. Rome, FAO. 69 pp.

GFCM. 2017c. Mid-term strategy (2017-2020) towards the sustainability of Mediterranean and Black Sea fisheries. Rome, FAO. 17 pp. (available at http://www.fao.org/3/a-i7340e. pdf)

GFCM. 2017d. Report of the coordination meeting for the implementation of scientific surveys in the Mediterranean. GFCM Secretariat. Rome, General Fisheries Commission for the Mediterranean. 21 pp. GFCM internal document.

GFCM. 2018a. Data Collection Reference Framework (DCRF). Version 19.1. GFCM Secretariat.

GFCM. 2018b. Report of the second meeting of the Working Group on Vulnerable Marine Ecosystems (WGVME), FAO headquarters, Rome, Italy, 26-28 February 2018. Rome, FAO. $57 \mathrm{pp}$.

GFCM. 2019a. Report of the forty-second session of the General Fisheries Commission for the Mediterranean (GFCM), FAO headquarters, Rome, Italy, 22-26 October 2018. GFCM Report No. 42. Rome. 146 pp.

GFCM. 2019b. Report of the Workshop on the harmonization of data collection at landing sites and in scientific surveys-at-sea, Burgas, Bulgaria, 3-5 April 2019. Rome, FAO. 40 pp. 
Giovanardi, O., Pranovi, F. \& Franceschini, G. 1998. Rapido trawl-fishing in the northern Adriatic: preliminary observations on effects on macrobenthic communities. Acta Adriat, 39: 3752

Hall-Spencer, J.M., Froglia, C., Atkinson, R.J.A. \& Moore, P.G. 1999. The impact of Rapido trawling for scallops, Pecten jacobaeus (L.), on the benthos of the Gulf of Venice. ICES Journal of Marine Science, 56: 111-124.

Hilborn, R. \& Walters, C.J. 1992. Quantitative fisheries stock assessment, choice, dynamics and uncertainty. Chapman and Hall, London. doi:10.1007/978-1-4615-3598-0

ICES. 2008. Report of the Workshop on Small Pelagics (Sardina pilchardus, Engraulis encrasicolus) maturity stages (WKSPMAT), 10-14 November 2008, Mazara del Vallo, Italy. ICES CM 2008/ACOM: 40. Copenhagen. $82 \mathrm{pp.}$

ICES, 2009. Report of the Study Group on Survey Trawl Standardisation (SGSTS) by correspondence. ICES CM 2009/FTC: 09. 127 pp.

ICES. 2010. Report of the Workshop on Implementation in DATRAS of Confidence Limits, Estimation. 10-12 May 2006, ICES Headquarters. Copenhagen, International Council for the Exploration of the Sea. 53 pp.

ICES. 2011. Manual for the Baltic International Trawl Surveys, March 2011, Kaliningrad, Russia. 73 pp.

ICES. 2012. Manual for the International Bottom Trawl Surveys. Series of ICES Survey Protocols. SISP 1-IBTS VIII. 68 pp.

IUCN. 2016. The conservation status of sharks, rays and chimaeras in the Mediterranean Sea. Campanillas (Málaga), Spain. 14 pp.

MacLennan, D.N., Fernandes, P.G. \& Dalen, J. 2002. A consistent approach to definitions and symbols in fisheries acoustics. ICES Journal of Marine Science, 59: 365-369.

MEDIAS. 2015. Common protocol for the Pan-Mediterranean Acoustic Survey (MEDIAS). Sète, France, March 2015. 21 pp. (available at http://www.medias-project.eu/medias/ website/handbooks-menu.html)

MEDIAS. 2017. Common protocol for the Pan-Mediterranean Acoustic Survey (MEDIAS). Palma de Mallorca, Spain, April 2017. 22 pp. (available at http://www.medias-project.eu/ medias/website/handbooks-menu.html)

MEDIAS. 2019. Common protocol for the MEDIterranean International Acoustic Survey (MEDIAS). Athens, Greece, April 2019. 14 pp. (available at http://www.medias-project. eu/medias/website/handbooks-menu.html).

MEDITS. 2016. International bottom trawl survey in the Mediterranean. Medits instruction manual. Version 8. 2016. MEDITS Working Group. 177 pp.

MEDITS. 2017. International bottom trawl survey in the Mediterranean. Medits instruction manual. Version 9. 2017. MEDITS Working Group. 106 pp.

Neyman, J. 1938. Contribution to the theory of sampling human populations. Journal of the American Statistical Association, 33:201, 101-116.

Oeberst, R. 2000. A universal cost function for the optimization of the number of age readings and length measurements for Age-Length-Key Tables (ALKT). Archive of Fishery and Marine Research, 48(1): 43-60.

Pinto, R., Patrício, J., Baeta, A., Fath, B.D., Neto, J.M. \& Marques, J.C. 2009. Review and evaluation of estuarine biotic indices to assess benthic condition. Ecological Indicators, 9: $1-25$.

Relini, G., Carpentieri, P. \& Murenu, M. 2008. Manuale di istruzioni Medits (Medits instruction manual). Biologia Marina Mediterranea, 15 (Suppl. 2). 78pp.

Simmonds, E.J. \& MacLennan, D.N. 2005. Fisheries acoustics: theory and practice. Oxford, UK, Blackwell Publishing. 437 pp.

SoleMon. 2017. Instruction manual: Rapido trawl survey in the Northern Adriatic Sea. Version 3. November, 2017. 44 pp. 
SoleMon. 2019. Instruction manual: Rapido trawl survey in the Northern Adriatic Sea. Version 4. November, 2019. 49 pp. (available at http://dcf-italia.cnr.it/assets/lineeguida/ lin1/2019/SOLEMON-Handbook_2019_Ver_4.pdf)

Sparre, P. \& Venema, S.C. 1998. Introduction to tropical fish stock assessment. FAO Fisheries and Aquaculture Technical Paper No. 306.1, Rev. 2. Rome, FAO. 407 pp.

Spedicato, M.T., Zupa, W., Carbonara, P., Fiorentino, F., Follesa, M.C., Galgani, F., Garcia, C., Jadaud, A., Ioakeimidis, C., Lazarakis, G., Lembo, G., Mandic, M., Maiorano, P., Sartini, M., Serena, F., Cau, A., Esteban, A., Isajlovic, I., Micallef, R. \& Thasitis, I. 2019. Spatial distribution of marine macro-litter on the seafloor in the northern Mediterranean Sea: the MEDITS initiative. Scientia Marina, 83S1: 257-270. (available at https://doi.org/10.3989/scimar.04987.14A)

UNEP/MAP. 2015. Marine litter assessment in the Mediterranean. UNEP/MAP, Athens, 2015. 45 pp. 


\section{ANNEXES}

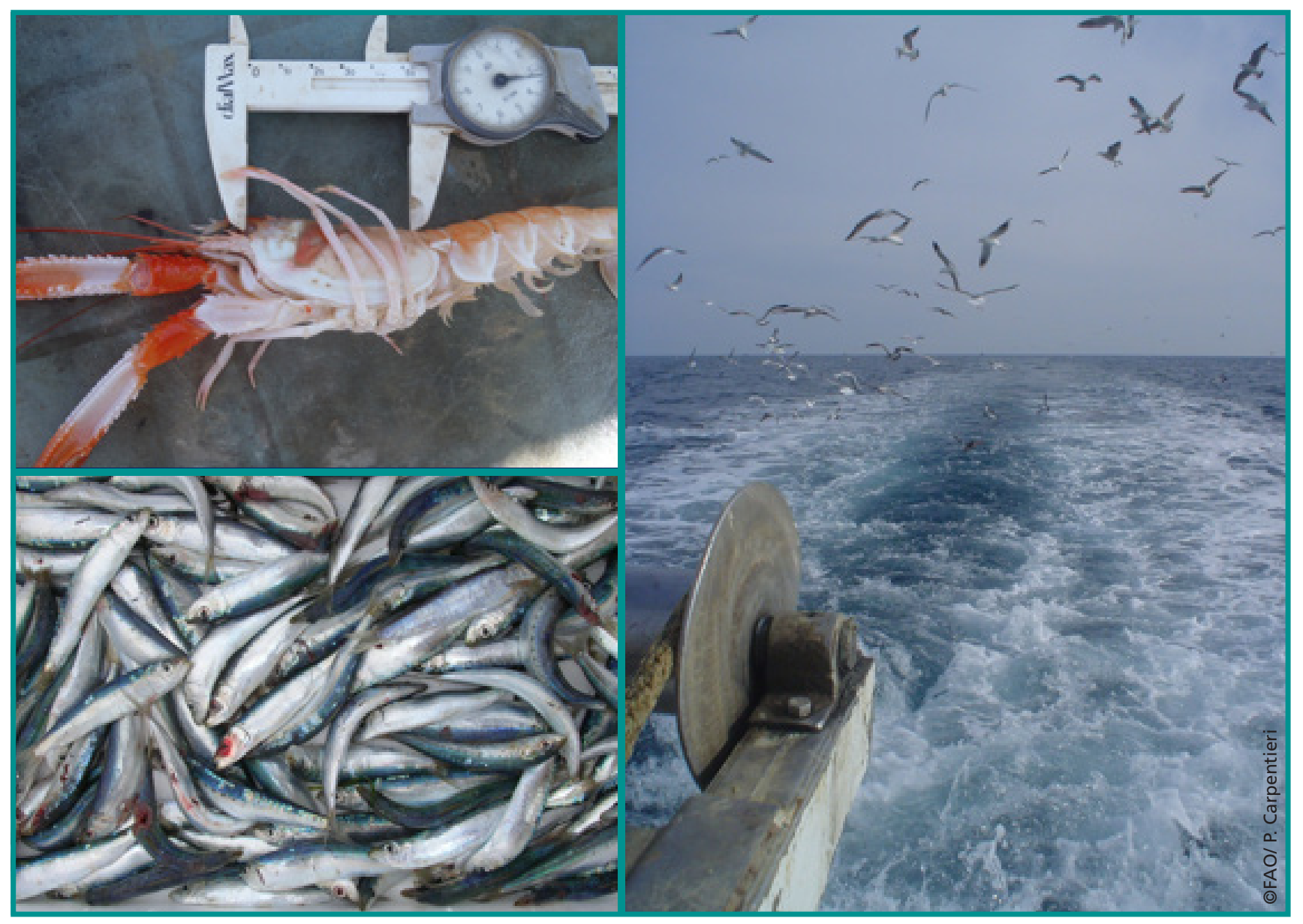



ANNEX 1. GFCM SUBREGIONS AND GEOGRAPHICAL SUBAREAS (GSAS)

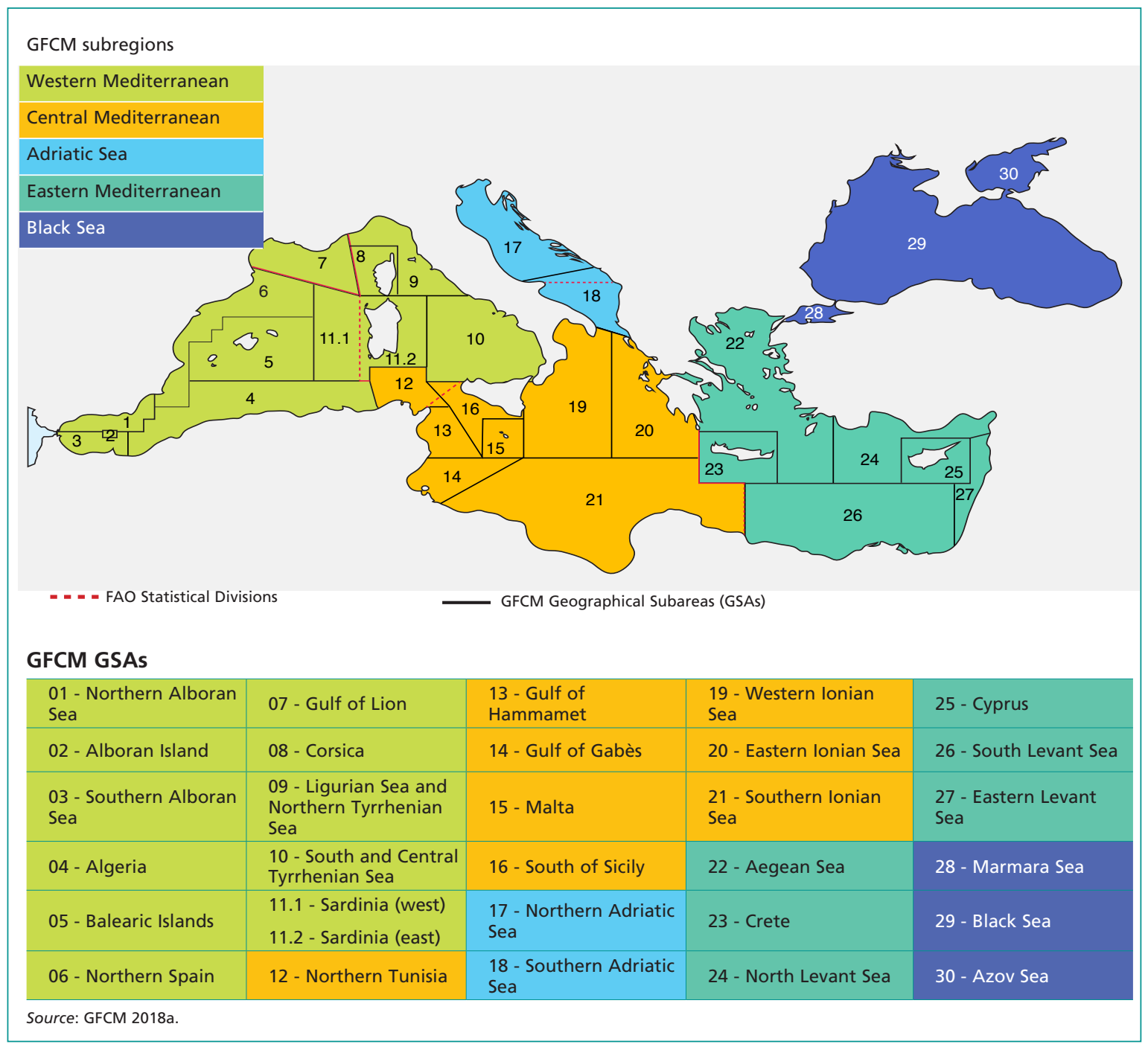


ANNEX 2. LIST OF PRIORITY SPECIES BY SUBREGION*

Annex 2.1. Group 1: species that drive the fishery and for which assessment is regularly carried out

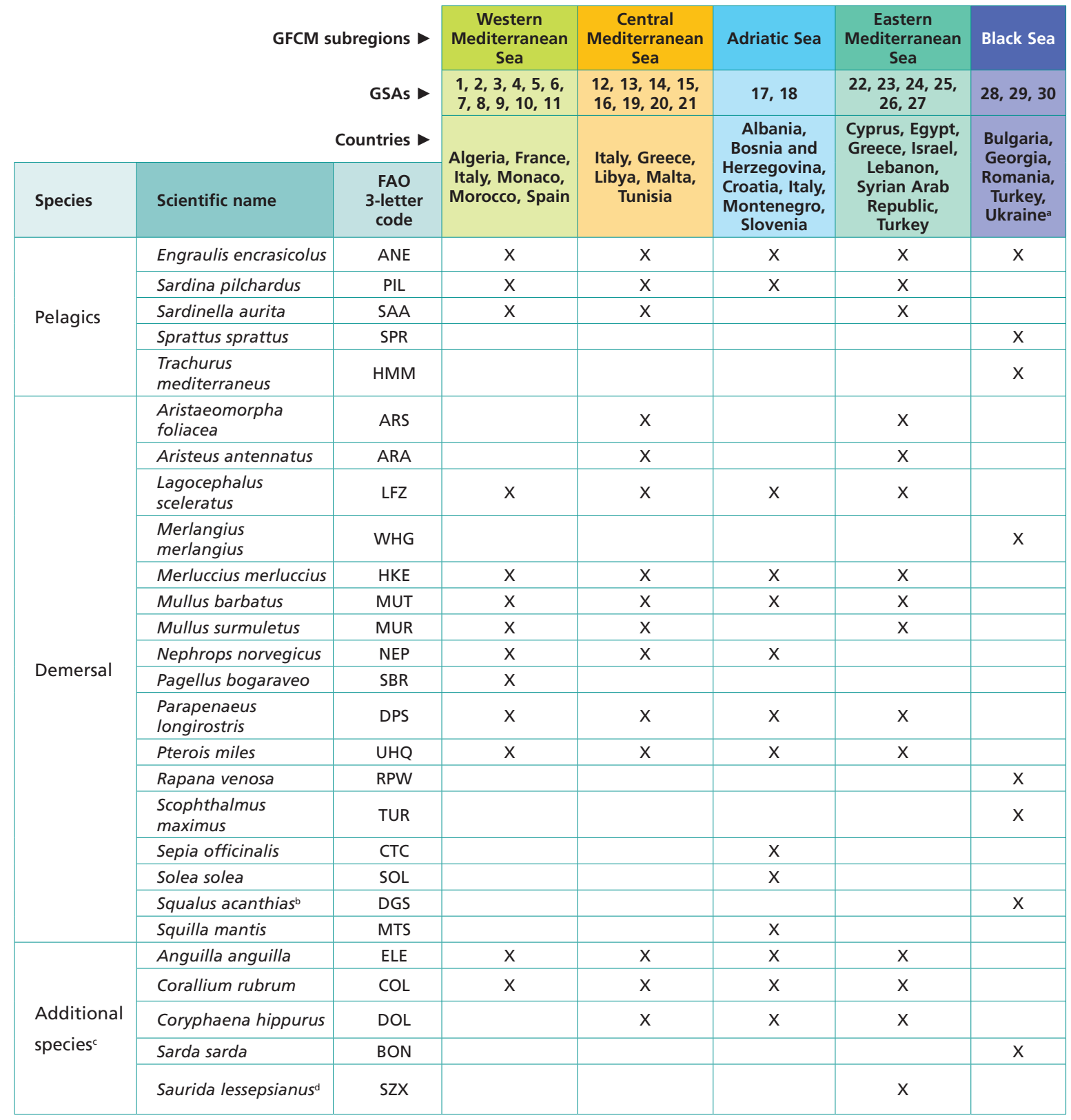

a All states, including GFCM non-contracting parties that are known to fish in the GFCM area of application, are encouraged to cooperate in joint actions undertaken in accordance with applicable international obligations (i.e. Article 63 of the United Nations Convention on the Law of the Sea [UNCLOS]).

b Species included in Annex III (species whose exploitation is regulated) of the Convention for the Protection of the Marine Environment and the Coastal Region of the Mediterranean (Barcelona Convention) - Protocol Concerning Specially Protected Areas and Biological Diversity in the Mediterranean.

' As identified by the mid-term strategy (2017-2020) towards the sustainability of Mediterranean and Black Sea fisheries (GFCM, 2016).

d The species is not currently present in the Aquatic Sciences and Fisheries Information System (ASFIS) list, and thus the 3-letter code of its genus (Saurida spp.) has been used.

* Note: The list of priority species (Groups 1, 2 and 3) is regularly updated by relevant GFCM subsidiary bodies, upon the approval of the GFCM at its annual sessions. 
Annex 2.2. Group 2: species that are important in terms of landings and/or economic value at the regional and subregional levels and for which assessment is not regularly carried out

\begin{tabular}{|c|c|c|c|c|c|c|}
\hline \multirow[b]{3}{*}{ Scientific name } & \multirow{3}{*}{\multicolumn{2}{|c|}{$\begin{array}{l}\text { Algeria, France, } \\
\text { Italy, Monaco, } \\
\text { Morocco, Spain }\end{array}$}} & \multirow{2}{*}{$\begin{array}{c}\text { Central } \\
\text { Mediterranean } \\
\text { Sea } \\
12,13,14,15,16, \\
19,20,21\end{array}$} & \multirow{2}{*}{$\begin{array}{c}\text { Adriatic Sea } \\
17,18\end{array}$} & \multirow{2}{*}{$\begin{array}{c}\text { Eastern } \\
\text { Mediterranean } \\
\text { Sea } \\
22,23,24,25 \\
26,27\end{array}$} & \multirow{2}{*}{$\begin{array}{l}\text { Black Sea } \\
28,29,30\end{array}$} \\
\hline & & & & & & \\
\hline & & & $\begin{array}{l}\text { Italy, Greece, } \\
\text { Libya, Malta, } \\
\text { Tunisia }\end{array}$ & $\begin{array}{l}\text { Albania, } \\
\text { Bosnia and } \\
\text { Herzegovina, } \\
\text { Croatia, Italy, } \\
\text { Montenegro, } \\
\text { Slovenia }\end{array}$ & $\begin{array}{c}\text { Cyprus, Egypt, } \\
\text { Greece, Israel, } \\
\text { Lebanon, Syrian } \\
\text { Arab Republic, } \\
\text { Turkey }\end{array}$ & $\begin{array}{c}\text { Bulgaria, } \\
\text { Georgia, } \\
\text { Romania, } \\
\text { Turkey, } \\
\text { Ukraine }^{\text {a }}\end{array}$ \\
\hline Alosa immaculata & SHC & & & & & $x$ \\
\hline Aristeus antennatus & ARA & $\mathrm{x}$ & & & & \\
\hline Boops boops & BOG & $x$ & $x$ & $x$ & $x$ & \\
\hline Chamelea gallina & SVE & & & $x$ & & \\
\hline Diplodus annularis & ANN & & $x$ & & & \\
\hline Eledone cirrhosa & EOI & $x$ & & $x$ & & \\
\hline Eledone moschata & EDT & & & $\mathrm{x}$ & & \\
\hline Galeus melastomus & $\mathrm{SHO}$ & $x$ & & & & \\
\hline Lophius budegassa & ANK & $x$ & $x$ & & & \\
\hline $\begin{array}{l}\text { Micromesistius } \\
\text { poutassou }\end{array}$ & WHB & $\mathrm{x}$ & & & & \\
\hline Octopus vulgaris & OCC & $x$ & $x$ & $x$ & $x$ & \\
\hline Pagellus erythrinus & PAC & $x$ & $x$ & $x$ & $x$ & \\
\hline Raja asterias & JRS & $x$ & & & & \\
\hline Raja clavata & RJC & $x$ & $x$ & & & \\
\hline Saurida undosquamis & LIB & & & & $x$ & \\
\hline Scomber japonicus & MAS & $x$ & & & $x$ & \\
\hline Scomber scombrus & MAC & $x$ & $x$ & & & \\
\hline Sepia officinalis & СTC & $x$ & $x$ & & & \\
\hline Siganus luridus & IGU & & & & $x$ & \\
\hline Siganus rivulatus & SRI & & & & $x$ & \\
\hline Solea solea & SOL & & & & $x$ & \\
\hline Sphyraena sphyraena & YRS & & $x$ & & & \\
\hline Spicara smaris & SPC & & & $x$ & $x$ & \\
\hline $\begin{array}{l}\text { Trachurus } \\
\text { mediterraneus }\end{array}$ & HMM & $\mathrm{x}$ & & & & \\
\hline Trachurus picturatus & JAA & $x$ & & & & \\
\hline Trachurus trachurus & HOM & $\mathrm{x}$ & $\mathrm{x}$ & & $\mathrm{x}$ & \\
\hline
\end{tabular}

${ }^{a}$ All states, including GFCM non-contracting parties that are known to fish in the GFCM area of application, are encouraged to cooperate in joint actions undertaken in accordance with applicable international obligations (i.e. Article 63 of UNCLOS). 
Annex 2.3. Group 3: species under international/national management plans and recovery and/or conservation action plans; non-indigenous species with greatest potential impact

\begin{tabular}{|c|c|c|c|c|c|c|}
\hline \multicolumn{2}{|c|}{ GFCM subregions } & $\begin{array}{c}\text { Western } \\
\text { Mediterranean }\end{array}$ & $\begin{array}{c}\text { Central } \\
\text { Mediterranean }\end{array}$ & Adriatic Sea & $\begin{array}{c}\text { Eastern } \\
\text { Mediterranean }\end{array}$ & Black Sea \\
\hline \multirow[b]{2}{*}{ Scientific name } & GSAs - & $\begin{array}{c}1,2,3,4,5,6,7 \\
8,9,10,11\end{array}$ & $\begin{array}{l}12,13,14,15 \\
16,19,20,21\end{array}$ & 17,18 & $\begin{array}{c}22,23,24,25 \\
26,27\end{array}$ & $28,29,30$ \\
\hline & $\begin{array}{c}\text { Countries } \\
\text { FAO } \\
\text { F-letter } \\
\text { code }\end{array}$ & $\begin{array}{l}\text { Algeria, France, } \\
\text { Italy, Monaco, } \\
\text { Morocco, Spain }\end{array}$ & $\begin{array}{c}\text { Italy, Greece, } \\
\text { Libya, Malta, } \\
\text { Tunisia }\end{array}$ & $\begin{array}{c}\text { Albania, } \\
\text { Bosnia and } \\
\text { Herzegovina, } \\
\text { Croatia, Italy, } \\
\text { Montenegro, } \\
\text { Slovenia }\end{array}$ & $\begin{array}{c}\text { Cyprus, Egypt, } \\
\text { Greece, Israel, } \\
\text { Lebanon, Syrian } \\
\text { Arab Republic, } \\
\text { Turkey }\end{array}$ & $\begin{array}{c}\text { Bulgaria, } \\
\text { Georgia, } \\
\text { Romania, } \\
\text { Turkey, } \\
\text { Ukraine }\end{array}$ \\
\hline Dalatias licha & SCK & $x$ & $x$ & $\mathrm{x}$ & $x$ & \\
\hline Dipturus oxyrinchus & RJO & $\mathrm{x}$ & $\mathrm{x}$ & $\mathrm{x}$ & $\mathrm{x}$ & \\
\hline Etmopterus spinax & ETX & $x$ & $x$ & $\mathrm{x}$ & $x$ & \\
\hline Galeus melastomus & $\mathrm{SHO}$ & & $x$ & $\mathrm{x}$ & $x$ & \\
\hline Hexanchus griseus & SBL & $x$ & $x$ & $x$ & $x$ & \\
\hline Mustelus asterias ${ }^{b}$ & SDS & $x$ & $x$ & $x$ & $x$ & \\
\hline Mustelus mustelus ${ }^{b}$ & SMD & $x$ & $x$ & $x$ & $x$ & \\
\hline Mustelus punctulatus ${ }^{b}$ & MPT & $x$ & $x$ & $x$ & $x$ & \\
\hline Myliobatis aquila & MYL & $x$ & $x$ & $x$ & $x$ & \\
\hline Prionace glaucab & BSH & $x$ & $x$ & $x$ & $x$ & \\
\hline Pteroplatytrygon violacea & PLS & $x$ & $x$ & $x$ & $x$ & \\
\hline Raja asterias & JRS & & $x$ & $x$ & $x$ & \\
\hline Raja clavata & RJC & & & $x$ & $x$ & $x$ \\
\hline Raja miraletus & JAI & $x$ & $x$ & $x$ & $x$ & \\
\hline Scyliorhinus canicula & SYC & $x$ & $x$ & $x$ & $x$ & $x$ \\
\hline Scyliorhinus stellaris & SYT & $x$ & $x$ & $x$ & $x$ & \\
\hline Squalus acanthias ${ }^{b}$ & DGS & $x$ & $x$ & $x$ & $x$ & \\
\hline Squalus blainville & QUB & $x$ & $x$ & $x$ & $x$ & \\
\hline Torpedo marmorata & TTR & $x$ & $x$ & $x$ & $x$ & \\
\hline Torpedo torpedo & TTV & $x$ & $x$ & $x$ & $x$ & \\
\hline Fistularia commersonii & $\mathrm{FIO}$ & & & & $x$ & \\
\hline Marsupenaeus japonicus & KUP & & & & $x$ & \\
\hline Metapenaeus stebbingi & MNG & & & & $x$ & \\
\hline Scomberomorus commerson & COM & & & & $\mathrm{x}$ & \\
\hline
\end{tabular}

a All states, including GFCM non-contracting parties that are known to fish in the GFCM area of application, are encouraged to cooperate in joint actions undertaken in accordance with applicable international obligations (i.e. Article 63 of UNCLOS).

b Species included in Annex III (species whose exploitation is regulated) of the Barcelona Convention - Protocol Concerning Specially Protected Areas and Biological Diversity in the Mediterranean. 
ANNEX 3. FISHING HAUL INFORMATION

Annex 3.1. Data entry sheet: main characteristics of each fishing haul

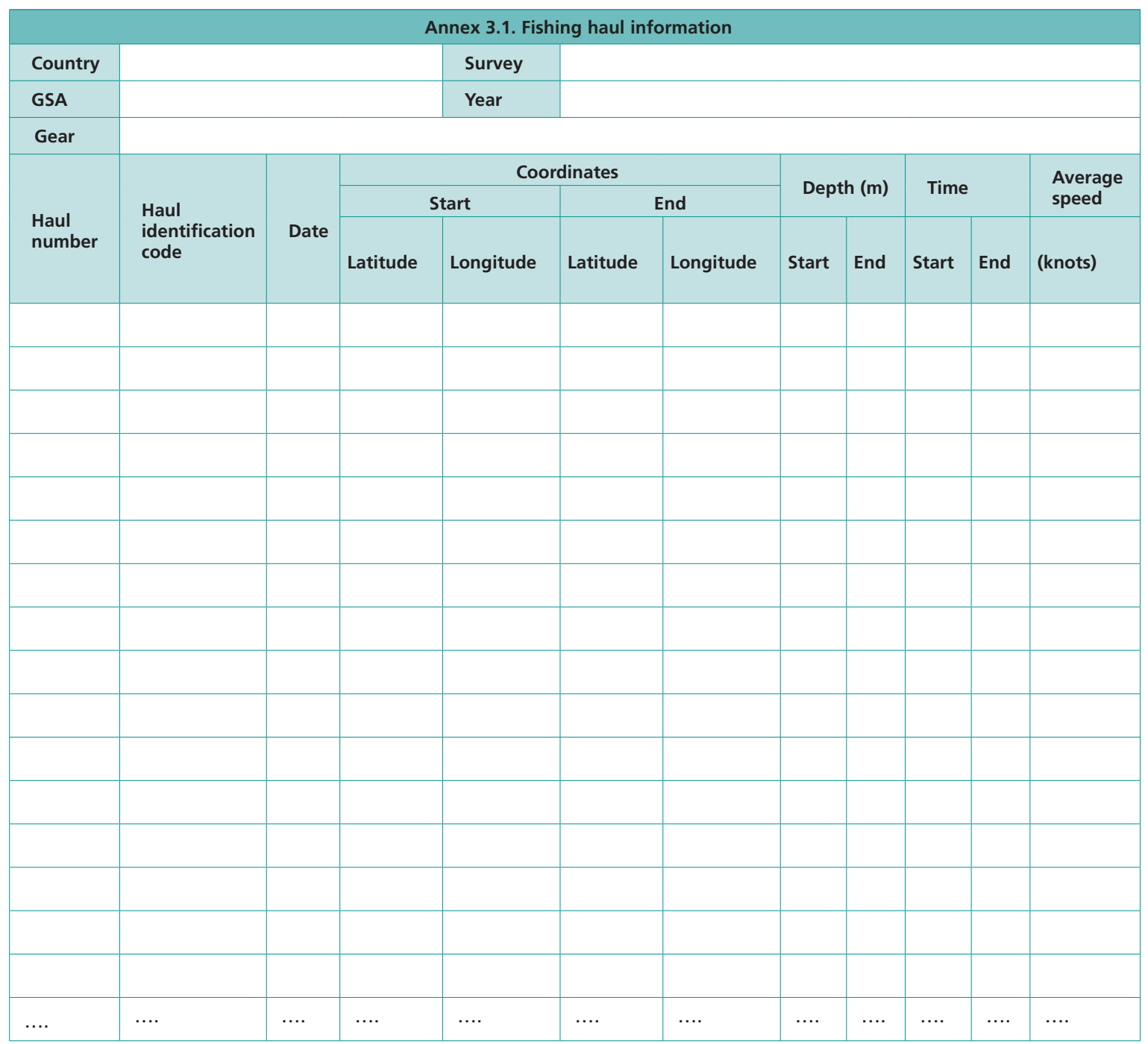

$\sqrt{ }$ This template can be reproduced several times (depending on the number of fishing hauls).

\section{Instructions}

- Survey: insert the name of the survey.

- GSA: insert the code of the geographical subarea (GSA) as in annex 1.

- Gear: insert the type of gear (e.g. bottom trawl, pelagic trawl) and the main characteristics including the mesh size of the codend.

- Haul number: insert the identification number that should be assigned to each fishing haul (e.g. progressive numbers from 1 to 100). Fishing hauls are made in the same position from year to year, the same number should be associated to a fishing haul every year.

- Haul identification code: insert the identification code that is assigned yearly to each fishing haul (unique).

- Coordinates: latitude (start and end) - insert the latitude at the beginning and at the end of each fishing haul; data should be inserted in degrees, minutes and seconds (e.g. 40 $51^{\prime} 59^{\prime \prime} \mathrm{N}$ ); longitude (start and end) - insert the longitude at the beginning and at the end of each fishing haul; data should be inserted in degrees, minutes and seconds (e.g. $124^{\circ} 4^{\prime} 58^{\prime \prime} \mathrm{W}$ ).

- Depth $(\mathrm{m})$ : insert the depth in metres at the beginning and at the end of each fishing haul.

- Time: insert the time at the beginning and at the end of each fishing haul.

- Average speed: insert the average speed maintained during the fishing haul. 


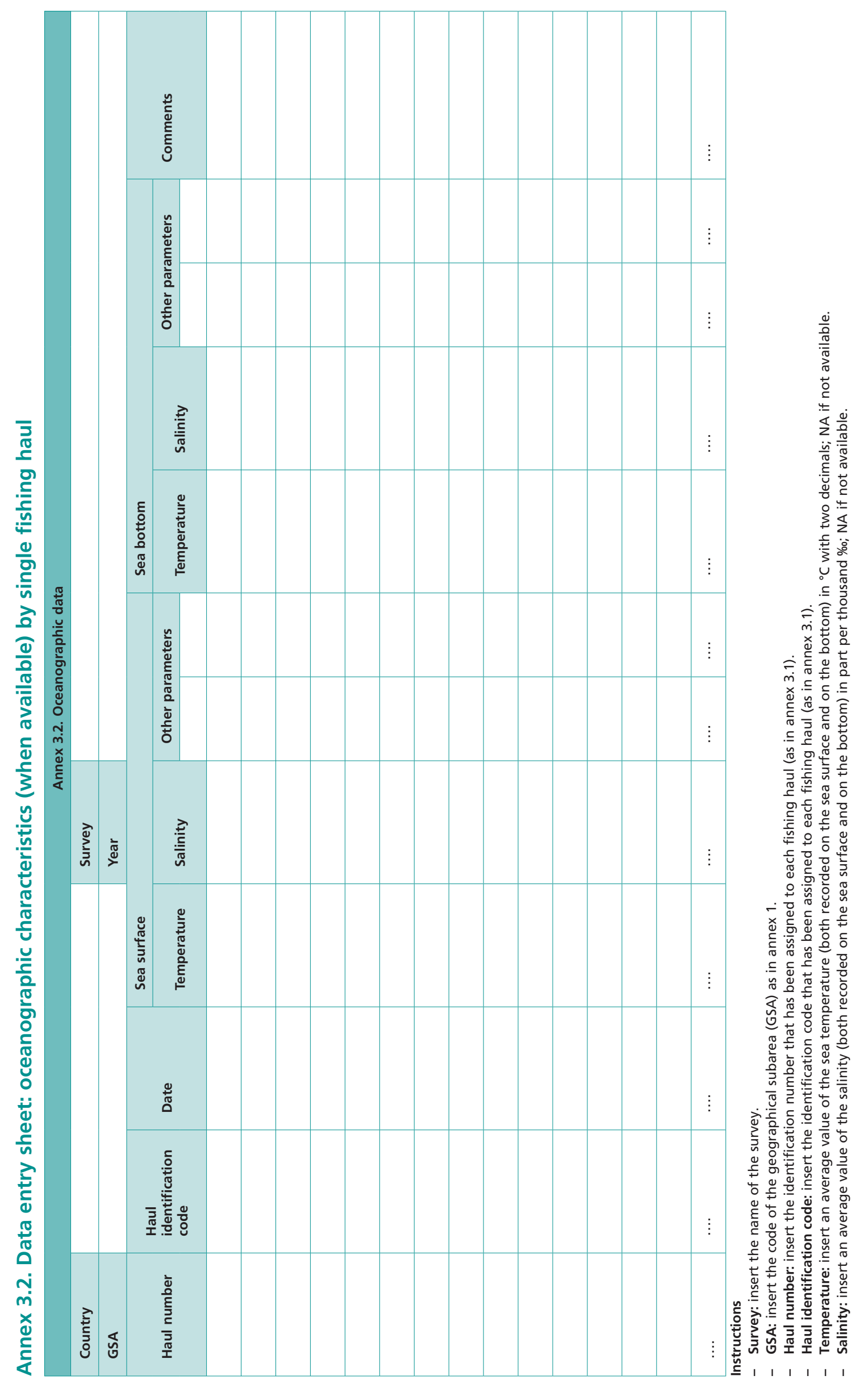


ANNEX 4. CATCH COMPOSITION BY FISHING HAUL

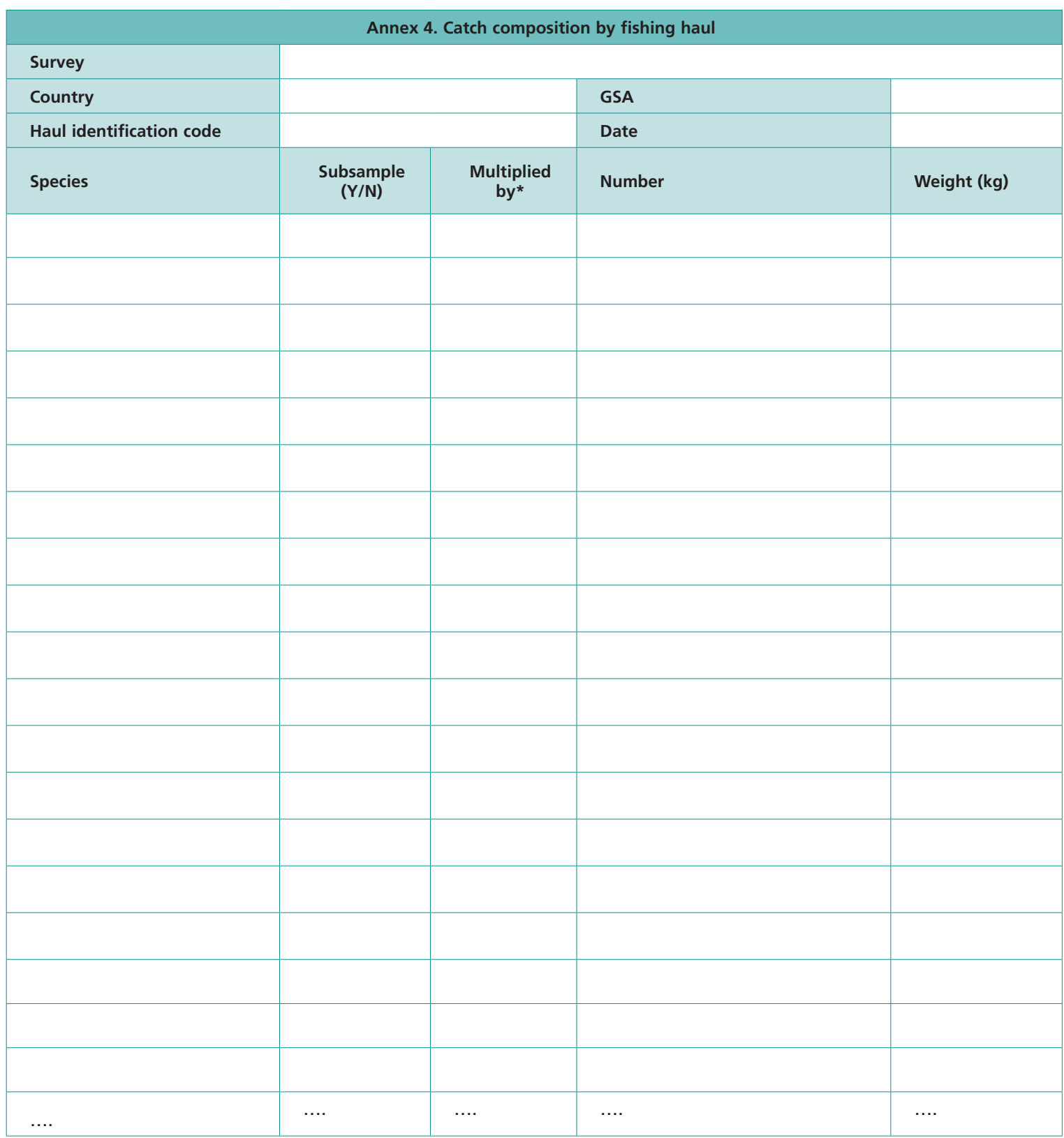

*to be filled only when data have been collected for a subsample of the catch.

$\sqrt{ }$ This template can be replicated several times (depending on the number of species caught during a single fishing haul)

\section{Instructions}

- Survey: Insert the name of the survey.

- GSA: Insert the code of the geographical subarea (GSA) as in annex 1.

- Haul identification code: Insert the identification code that has been assigned to the identified fishing haul (as in annex 3.1).

- Species: Insert the scientific name for all the species present in the catch composition.

- Subsample (y/n): For each species caught during the same fishing haul, indicate "Yes" if data (on weight and number) have been collected for a subsample; otherwise, indicate "No".

- Multiplied by: Indicate the number by the subsample should be multiplied.

- Number: Insert the total number of individuals present in the catch (or in the subsample) for the identified species

- Weight (kg): Insert the total weight (in $\mathrm{kg}$ ) of the individuals present in the catch (or in the subsample) for the identified species. 
ANNEX 5. LENGTH DATA BY FISHING HAUL

Annex 5.1. Data entry sheet: length data for fish, cephalopods and elasmobranchs

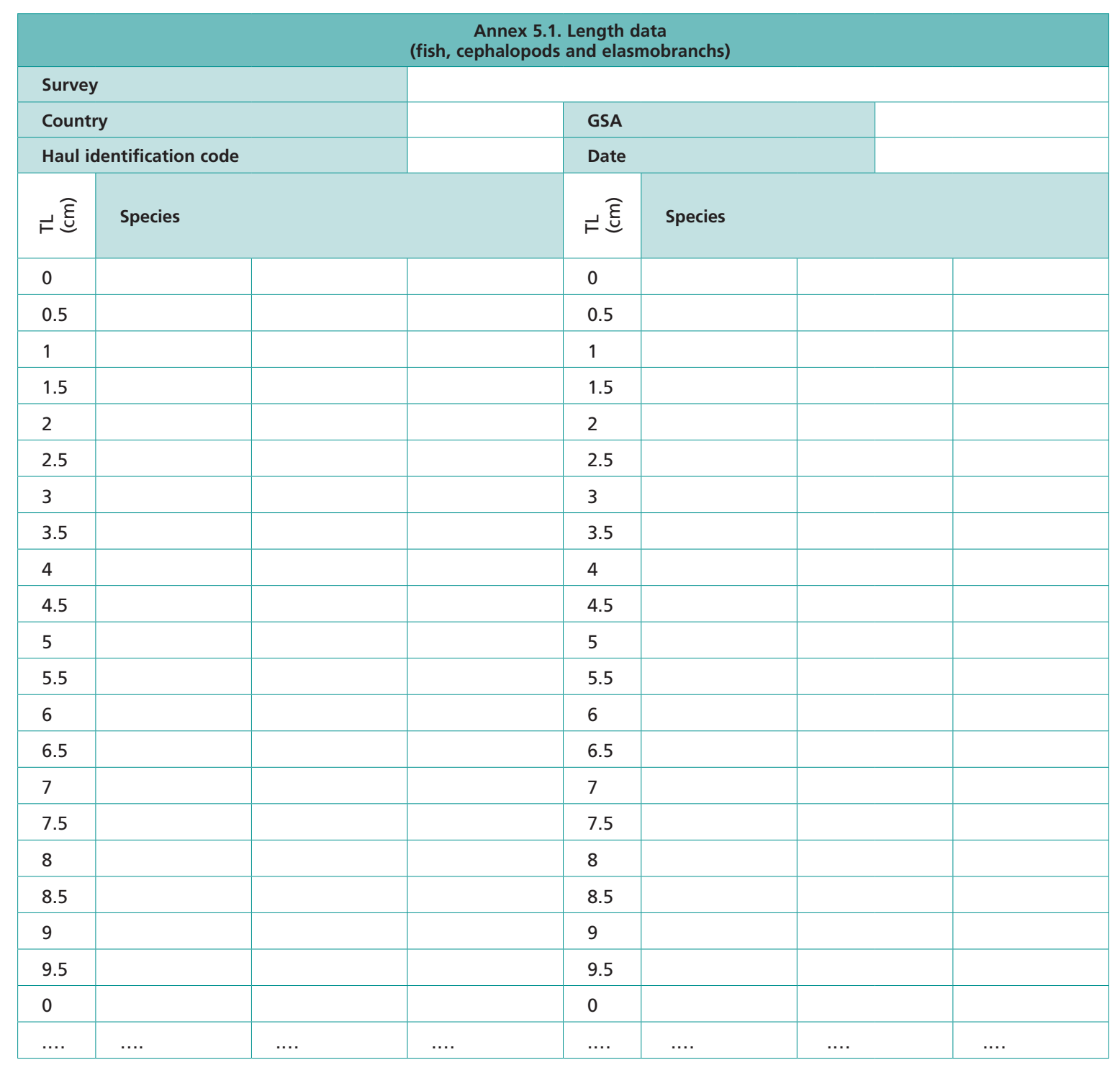

$\sqrt{ }$ This template should be duplicated for the different species caught during the same fishing haul and for which length data (in centimetres) should be collected.

Instructions

- Survey: insert the name of the survey.

- GSA: insert the code of the geographical subarea (GSA) as in annex 1.

- Haul identification code: insert the identification code that has been assigned to the identified fishing haul (as in annex 3.1).

- Species: insert the scientific name of the identified species. 
Annex 5.2. Data entry sheet: length data for crustaceans

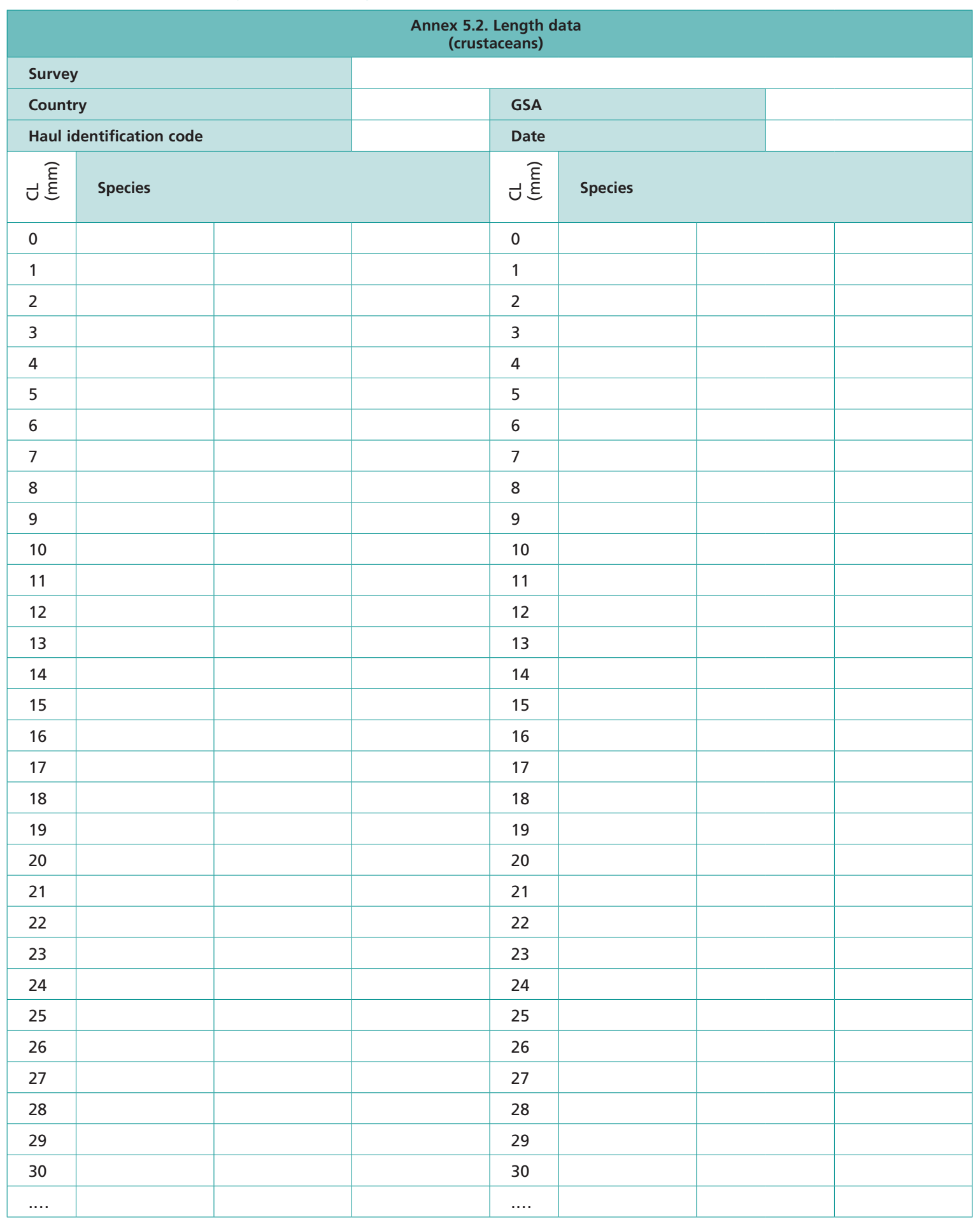

$\sqrt{ }$ This template should be duplicated for the different species caught during the same fishing haul and for which length data (in millimetres) should be collected.

\section{Instructions}

- Survey: insert the name of the survey.

- GSA: insert the code of the geographical subarea (GSA) as in annex 1.

- Haul identification code: insert the identification code that has been assigned to the identified fishing haul (as in annex 3.1).

- Species: insert the scientific name of the identified species. 


\section{ANNEX 6. INDIVIDUAL WEIGHT BY SPECIES}

Annex 6.1. Data entry sheet: individual weight by species

\begin{tabular}{|c|c|c|c|c|c|}
\hline \multicolumn{6}{|c|}{ Annex 6.1. Individual weight data } \\
\hline \multicolumn{2}{|l|}{ Survey } & & & & \\
\hline \multicolumn{2}{|l|}{ Country } & & \multicolumn{3}{|l|}{ GSA } \\
\hline \multicolumn{2}{|c|}{ Haul identification code } & & \multicolumn{3}{|l|}{ Date } \\
\hline \multicolumn{6}{|l|}{ Species } \\
\hline \multicolumn{2}{|c|}{ Total weight in the catch } & & \multicolumn{3}{|c|}{ Weight of the sample } \\
\hline $\begin{array}{l}\text { Progressive } \\
\text { number }\end{array}$ & $\begin{array}{l}\text { Length } \\
\text { (total } L \text { in } \mathrm{cm} \text {, mantle } \\
L \text { in } \mathrm{cm} \text { or carapax } L \\
\text { in } \mathrm{mm} \text { ) }\end{array}$ & Weight (g) & $\begin{array}{l}\operatorname{Sex}^{*} \\
(F, M, U, N D)\end{array}$ & $\begin{array}{l}\text { Maturity } \\
\text { stage** }\end{array}$ & $\begin{array}{l}\text { Otoliths } \\
(\mathrm{Y} / \mathrm{N})\end{array}$ \\
\hline \multicolumn{6}{|l|}{1} \\
\hline \multicolumn{6}{|l|}{2} \\
\hline \multicolumn{6}{|l|}{3} \\
\hline \multicolumn{6}{|l|}{4} \\
\hline \multicolumn{6}{|l|}{5} \\
\hline \multicolumn{6}{|l|}{6} \\
\hline \multicolumn{6}{|l|}{7} \\
\hline \multicolumn{6}{|l|}{8} \\
\hline \multicolumn{6}{|l|}{9} \\
\hline \multicolumn{6}{|l|}{10} \\
\hline \multicolumn{6}{|l|}{11} \\
\hline \multicolumn{6}{|l|}{12} \\
\hline \multicolumn{6}{|l|}{13} \\
\hline \multicolumn{6}{|l|}{14} \\
\hline \multicolumn{6}{|l|}{15} \\
\hline \multicolumn{6}{|l|}{16} \\
\hline \multicolumn{6}{|l|}{17} \\
\hline \multicolumn{6}{|l|}{18} \\
\hline 19 & & & & & \\
\hline 20 & & & & & \\
\hline 21 & & & & & \\
\hline 22 & & & & & \\
\hline 23 & & & & & \\
\hline 24 & & & & & \\
\hline 25 & & & & & \\
\hline 26 & & & & & \\
\hline 27 & & & & & \\
\hline 28 & & & & & \\
\hline 29 & & & & & \\
\hline 30 & & & & & \\
\hline$\ldots$ & $\ldots$. & $\ldots$. & $\ldots$. & $\ldots$. & $\ldots$. \\
\hline
\end{tabular}

*if available

$\sqrt{ }$ This template should be duplicated for the different species caught during the same fishing haul and for which individual weight (in grams) should be collected.

Instructions

- Survey: insert the name of the survey.

- GSA: insert the code of the geographical subarea (GSA) as in annex 1.

- Haul identification code: insert the identification code that has been assigned to the identified fishing haul (as in annex 3.1).

- Species: insert the scientific name of the identified species.

- Length: for each identified specimen, depending on the species, insert the total and/or the mantle length (in $\mathrm{cm}$ ), or the carapax length (in $\mathrm{mm}$ ).

- Weight: for each identified specimen, insert the total weight (in grams)

- Length: for each identified specimen, depending on the species, insert the total and/or the mantle length (in $\mathrm{cm}$ ), or the carapax length (in $\mathrm{mm}$ ).

- Sex*: if available, insert the sex of the identified specimen ( $M=$ male; $F=$ female; $U=$ undetermined; ND=not determined).

- Maturity stage*: if available, insert the maturity stage of the identified specimen following the maturity scales reported in annex 8 (in the case of anchovy and sardine caught during a pelagic survey, see annex 9). 
Annex 6.2. Data entry sheet: weight by length class

\begin{tabular}{|c|c|c|c|}
\hline \multicolumn{4}{|c|}{ Annex 6.2. Weight by length class } \\
\hline \multicolumn{4}{|l|}{ Survey } \\
\hline Country & & GSA & \\
\hline Haul identification code & & Date & \\
\hline \multicolumn{4}{|l|}{ Species } \\
\hline Total weight in the catch & & Weight of the whole sample & \\
\hline Length class & $\begin{array}{l}\text { Number of specimens by } \\
\text { length class }\end{array}$ & $\begin{array}{l}\text { Total weight by length } \\
\text { class }(g)\end{array}$ & Mean weight per specimen \\
\hline & & & \\
\hline & & & \\
\hline & & & \\
\hline & & & \\
\hline & & & \\
\hline & & & \\
\hline & & & \\
\hline & & & \\
\hline & & & \\
\hline & & & \\
\hline & & & \\
\hline & & & \\
\hline & & & \\
\hline & & & \\
\hline & & & \\
\hline & & & \\
\hline & & & \\
\hline & & & \\
\hline & & & \\
\hline & & & \\
\hline & & & \\
\hline & & & \\
\hline & & & \\
\hline & & & \\
\hline & & & \\
\hline & & & \\
\hline & & & \\
\hline & & & \\
\hline & & & \\
\hline & & & \\
\hline$\cdots$ & $\ldots$ & $\ldots$. & $\ldots$ \\
\hline
\end{tabular}

$\sqrt{ }$ This template should be duplicated for the different species caught during the same fishing haul and for which information by length class should be collected.

Instructions

- Survey: insert the name of the survey.

- GSA: insert the code of the geographical subarea (GSA) as in annex 1.

- Haul identification code: insert the identification code that has been assigned to the identified fishing haul (as in annex 3.1).

- Species: insert the scientific name of the identified species.

- Length class: for the identified species, depending on the species in $\mathrm{cm}$ or $\mathrm{mm}$, insert the identified length classes.

- Number of specimens by length class: for each identified length class, insert the total number of specimens.

- Total weight by length class (g): for each identified length class, insert the total weight of specimens present.

- Mean weight per specimen: for each identified length class, insert the mean weight of a single specimen (i.e. total weight divided the number of specimens) 
ANNEX 7. SEX AND MATURITY DATA

Annex 7.1. Data entry sheet: sex and maturity data for fish

\begin{tabular}{|c|c|c|c|c|c|c|c|c|c|c|c|c|c|c|c|c|c|}
\hline \multicolumn{18}{|c|}{$\begin{array}{l}\text { Annex 7.1. Sex and maturity data } \\
\text { (fish) }\end{array}$} \\
\hline \multicolumn{18}{|c|}{ Survey } \\
\hline \multicolumn{5}{|c|}{ Country } & & & & & \multicolumn{2}{|c|}{ GSA } & & & & & & & \\
\hline \multicolumn{5}{|c|}{ Haul identification code } & & & & & \multicolumn{2}{|c|}{ Date } & & & & & & & \\
\hline \multicolumn{18}{|c|}{ Species } \\
\hline \multirow{3}{*}{$\begin{array}{l}\widehat{E} \\
\vec{F}\end{array}$} & \multicolumn{7}{|c|}{ Male } & \multirow{3}{*}{ 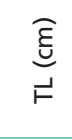 } & \multicolumn{7}{|c|}{ Female } & \multirow{3}{*}{$\begin{array}{l}\underset{\vec{E}}{\vec{f}} \\
.\end{array}$} & \multirow{3}{*}{$\begin{array}{l}\text { Undetermined/ } \\
\text { Not determined }\end{array}$} \\
\hline & \multirow{2}{*}{$\begin{array}{l}1 \\
1\end{array}$} & \multicolumn{3}{|l|}{2} & \multirow{2}{*}{\begin{tabular}{|l|}
3 \\
3
\end{tabular}} & \multicolumn{2}{|l|}{4} & & 1 & \multicolumn{3}{|c|}{2} & \multirow{2}{*}{$\begin{array}{l}3 \\
3\end{array}$} & \multicolumn{2}{|l|}{4} & & \\
\hline & & $2 a$ & $2 b$ & $2 c$ & & $4 a$ & $4 b$ & & 1 & $2 a$ & $2 b$ & $2 c$ & & $4 a$ & $4 b$ & & \\
\hline 0 & & & & & & & & 0 & & & & & & & & 0 & \\
\hline 0.5 & & & & & & & & 0.5 & & & & & & & & 0.5 & \\
\hline 1 & & & & & & & & 1 & & & & & & & & 1 & \\
\hline 1.5 & & & & & & & & 1.5 & & & & & & & & 1.5 & \\
\hline 2 & & & & & & & & 2 & & & & & & & & 2 & \\
\hline 2.5 & & & & & & & & 2.5 & & & & & & & & 2.5 & \\
\hline 3 & & & & & & & & 3 & & & & & & & & 3 & \\
\hline 3.5 & & & & & & & & 3.5 & & & & & & & & 3.5 & \\
\hline 4 & & & & & & & & 4 & & & & & & & & 4 & \\
\hline 4.5 & & & & & & & & 4.5 & & & & & & & & 4.5 & \\
\hline 5 & & & & & & & & 5 & & & & & & & & 5 & \\
\hline 5.5 & & & & & & & & 5.5 & & & & & & & & 5.5 & \\
\hline 6 & & & & & & & & 6 & & & & & & & & 6 & \\
\hline 6.5 & & & & & & & & 6.5 & & & & & & & & 6.5 & \\
\hline 7 & & & & & & & & 7 & & & & & & & & 7 & \\
\hline 7.5 & & & & & & & & 7.5 & & & & & & & & 7.5 & \\
\hline 8 & & & & & & & & 8 & & & & & & & & 8 & \\
\hline 8.5 & & & & & & & & 8.5 & & & & & & & & 8.5 & \\
\hline 9 & & & & & & & & 9 & & & & & & & & 9 & \\
\hline 9.5 & & & & & & & & 9.5 & & & & & & & & 9.5 & \\
\hline 0 & & & & & & & & 0 & & & & & & & & 0 & \\
\hline$\ldots$ & & & & & & & & $\ldots$ & & & & & & & & $\ldots$ & \\
\hline
\end{tabular}

$\sqrt{ }$ This template should be duplicated for the different species caught during the same fishing haul and for which sex and maturity information should be collected

$\sqrt{ }$ Maturity stages for the identified species should be reported following the maturity scales indicated in annex 8 (in case of species caught during a pelagic survey, see annex 9).

Instructions

- Survey: insert the name of the survey.

- GSA: insert the code of the geographical subarea (GSA) as in annex 1.

- Haul identification code: insert the identification code that has been assigned to the identified fishing haul (as in annex 3.1).

- Species: insert the scientific name of the identified species. 
Annex 7.2. Data entry sheet: sex and maturity data for crustaceans

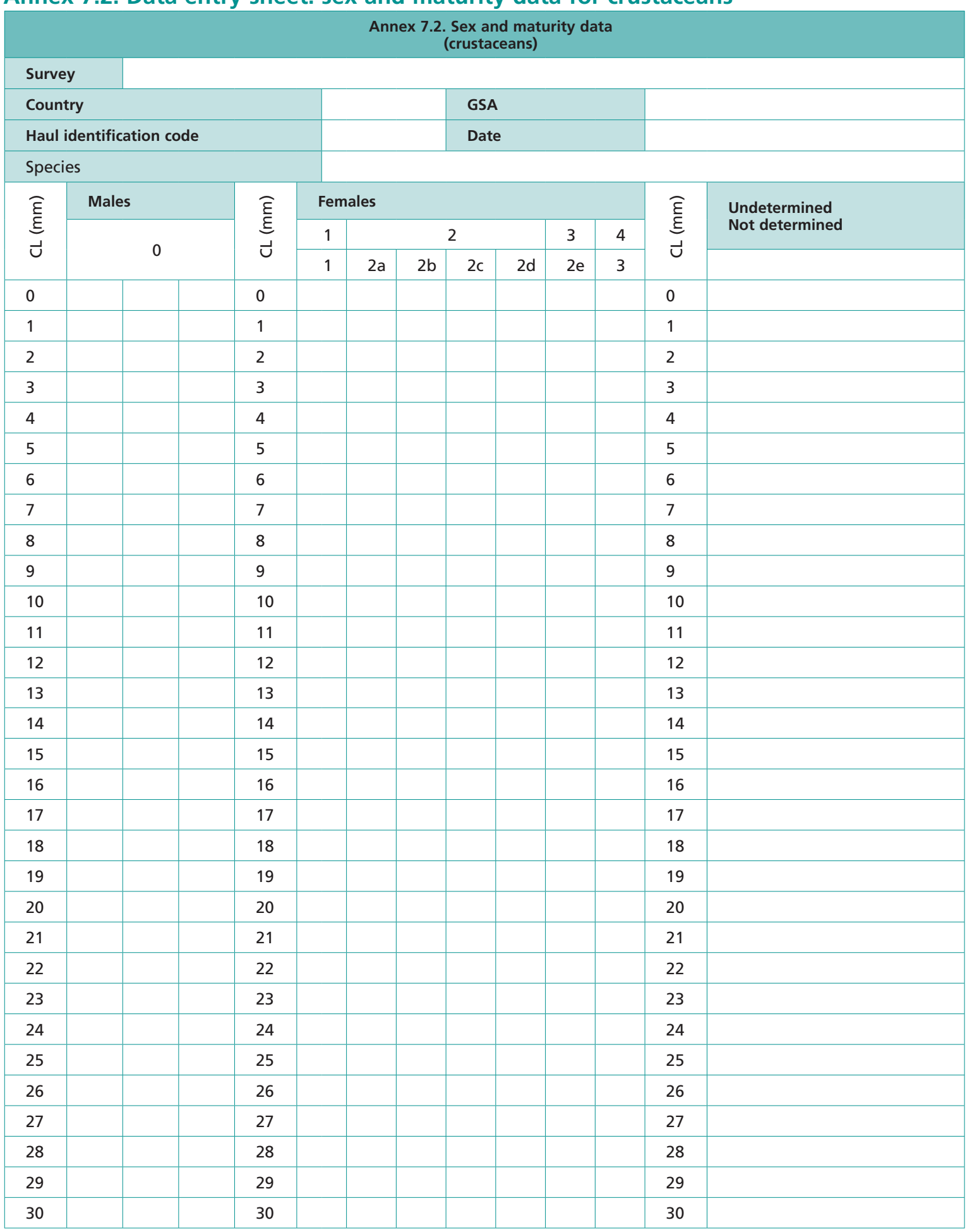

$\sqrt{ }$ This template should be duplicated for the different species caught during the same fishing haul and for which sex and maturity information should be collected

$\sqrt{ }$ Maturity stages for the identified species should be reported following the maturity scales as indicated in annex 8 .

Instructions

- Survey: insert the name of the survey.

- GSA: insert the code of the geographical subarea (GSA) as in annex 1.

- Haul identification code: insert the identification code that has been assigned to the identified fishing haul (as in annex 3.1).

- Species: insert the scientific name of the identified species. 
Annex 7.3. Data entry sheet: sex and maturity data for cephalopods

\begin{tabular}{|c|c|c|c|c|c|c|c|c|c|}
\hline \multicolumn{10}{|c|}{$\begin{array}{l}\text { Annex 7.3. Sex and maturity data } \\
\text { (cephalopods) }\end{array}$} \\
\hline \multicolumn{10}{|c|}{ Survey } \\
\hline \multicolumn{4}{|c|}{ Country } & & & & GSA & & \\
\hline \multicolumn{4}{|c|}{ Haul identification code } & & & & Date & & \\
\hline \multicolumn{10}{|c|}{ Species } \\
\hline \multirow{3}{*}{$\begin{array}{l}\widehat{E} \\
\vec{\Sigma}\end{array}$} & \multicolumn{4}{|c|}{ Males } & \multirow{3}{*}{$\frac{\widehat{\underline{E}}}{\vec{\Sigma}}$} & \multicolumn{2}{|c|}{ Females } & \multirow{3}{*}{$\frac{\widehat{E}}{\vec{E}}$} & \multirow{3}{*}{$\begin{array}{l}\text { Undetermined/ } \\
\text { Not determined }\end{array}$} \\
\hline & 1 & \multicolumn{2}{|c|}{2} & 3 & & 1 & 2 & & \\
\hline & 1 & $2 a$ & $2 k$ & & & 1 & $2 b$ & & \\
\hline 0 & & & & & 0 & & & 0 & \\
\hline 0.5 & & & & & 0.5 & & & 0.5 & \\
\hline 1 & & & & & 1 & & & 1 & \\
\hline 1.5 & & & & & 1.5 & & & 1.5 & \\
\hline 2 & & & & & 2 & & & 2 & \\
\hline 2.5 & & & & & 2.5 & & & 2.5 & \\
\hline 3 & & & & & 3 & & & 3 & \\
\hline 3.5 & & & & & 3.5 & & & 3.5 & \\
\hline 4 & & & & & 4 & & & 4 & \\
\hline 4.5 & & & & & 4.5 & & & 4.5 & \\
\hline 5 & & & & & 5 & & & 5 & \\
\hline 5.5 & & & & & 5.5 & & & 5.5 & \\
\hline 6 & & & & & 6 & & & 6 & \\
\hline 6.5 & & & & & 6.5 & & & 6.5 & \\
\hline 7 & & & & & 7 & & & 7 & \\
\hline 7.5 & & & & & 7.5 & & & 7.5 & \\
\hline 8 & & & & & 8 & & & 8 & \\
\hline 8.5 & & & & & 8.5 & & & 8.5 & \\
\hline 9 & & & & & 9 & & & 9 & \\
\hline 9.5 & & & & & 9.5 & & & 9.5 & \\
\hline 0 & & & & & 0 & & & 0 & \\
\hline$\ldots$ & & & & & $\ldots$. & & & $\ldots$ & \\
\hline
\end{tabular}

$\sqrt{ }$ This template should be duplicated for the different species caught during the same fishing haul and for which sex and maturity information should be collected

$\sqrt{ }$ Maturity stages for the identified species should be reported following the maturity scales as indicated in annex 8 .

Instructions

- Survey: insert the name of the survey.

- GSA: insert the code of the geographical subarea (GSA) as in annex 1.

- Haul identification code: insert the identification code which has been assigned to the identified fishing haul (as in annex 3.1).

- Species: insert the scientific name of the identified species. 
Annex 7.4. Data entry sheet: sex and maturity data for elasmobranchs

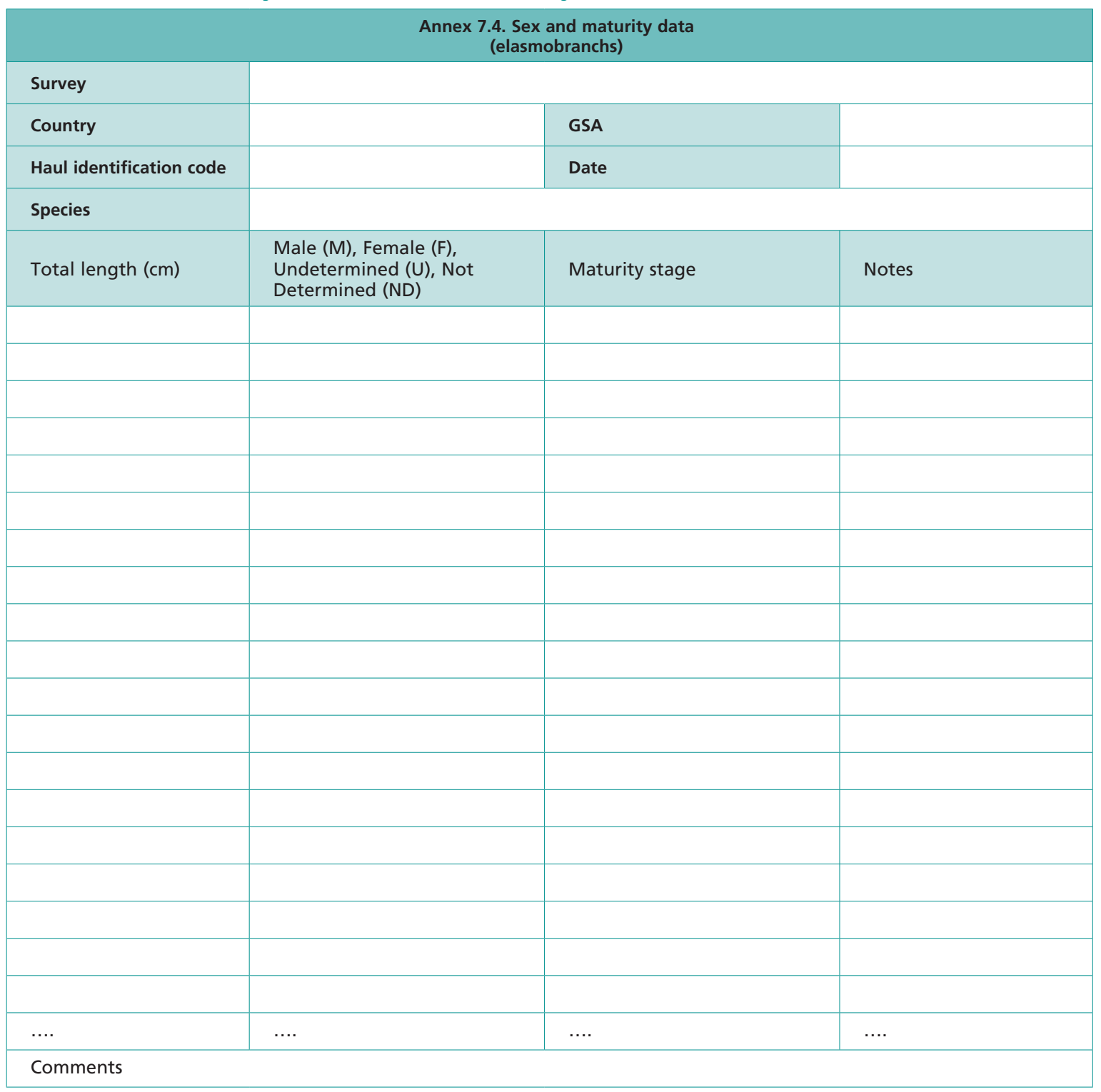

$\checkmark$ This template should be duplicated for the different species caught during the same fishing haul and for which sex and maturity information should be collected

$\sqrt{ }$ Maturity stages for the identified species should be reported following the maturity scales as indicated in annex 8 .

\section{Instructions}

- Survey: insert the name of the survey.

- GSA: insert the code of the geographical subarea (GSA) as in annex 1.

- Haul identification code: insert the identification code which has been assigned to the identified fishing haul (as in annex 3.1).

- Species: insert the scientific name of the identified species.

- Total length: report in $\mathrm{cm}$ (to the lower half centimetre) the total length of each single specimen of elasmobranch measured.

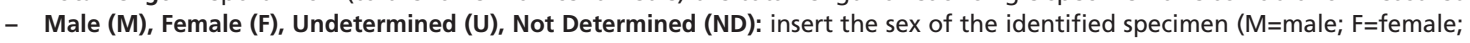
$\mathrm{U}=$ undetermined; $\mathrm{ND}=$ not determined). 


\section{ANNEX 8. MATURITY SCALES}

\section{Annex 8.1. Maturity scale for bony fish}

\begin{tabular}{|c|c|c|c|}
\hline \multicolumn{4}{|c|}{$\begin{array}{c}\text { Annex 8.1. Maturity scale } \\
\text { (bony fish) }\end{array}$} \\
\hline Stages & Maturation state & \multicolumn{2}{|l|}{ Reproductive apparatus aspect } \\
\hline 0 & UNDETERMINED & \multicolumn{2}{|c|}{$\begin{array}{l}\text { Sex not distinguished by naked eye. Gonads very small and translucent, } \\
\text { almost transparent. Sex undetermined. }\end{array}$} \\
\hline & & Females & Males \\
\hline 1 & IMMATURE-VIRGIN & $\begin{array}{l}\text { Small pinkish and translucent ovary } \\
\text { shorter than } 1 / 3 \text { of body cavity. Eggs } \\
\text { not visible to naked eye. }\end{array}$ & $\begin{array}{l}\text { Thin and whitish testis shorter } \\
\text { than } 1 / 3 \text { of body cavity. }\end{array}$ \\
\hline $2 a$ & VIRGIN-DEVELOPING & $\begin{array}{l}\text { Small pinkish/reddish ovary shorter } \\
\text { than } 1 / 2 \text { of body cavity. Eggs not } \\
\text { visible to naked eye. }\end{array}$ & $\begin{array}{l}\text { Thin whitish testis shorter than } \\
1 / 2 \text { of body cavity. }\end{array}$ \\
\hline $2 b$ & RECOVERING & $\begin{array}{l}\text { Pinkish-reddish/reddish-orange and } \\
\text { translucent ovary; length about } 1 / 2 \text { of } \\
\text { body cavity. Blood vessels visible. Eggs } \\
\text { not visible to naked eye. }\end{array}$ & $\begin{array}{l}\text { Whitish/pinkish testis, more or } \\
\text { less symmetrical; length about } \\
1 / 2 \text { of body cavity. }\end{array}$ \\
\hline 2c & MATURING & $\begin{array}{l}\text { Ovary pinkish-yellow in colour with } \\
\text { granular appearance; length about } \\
2 / 3 \text { of body cavity. Eggs are visible to } \\
\text { naked eye through the ovaric tunica, } \\
\text { which is not yet translucent. Under } \\
\text { light pressure, eggs are not expelled. }\end{array}$ & $\begin{array}{l}\text { Whitish to creamy testis; length } \\
\text { about } 2 / 3 \text { of body cavity. Under } \\
\text { light pressure, sperm is not } \\
\text { expelled. }\end{array}$ \\
\hline 3 & MATURE/SPAWNER & $\begin{array}{l}\text { Ovary orange-pink in colour, with } \\
\text { conspicuous superficial blood vessels; } \\
\text { length from } 2 / 3 \text { to full length of } \\
\text { body cavity. Large transparent, ripe } \\
\text { eggs are clearly visible and could be } \\
\text { expelled under light pressure. In more } \\
\text { advanced conditions, eggs escape } \\
\text { freely. }\end{array}$ & $\begin{array}{l}\text { Whitish-creamy soft testis; length } \\
\text { from } 2 / 3 \text { to full length of body } \\
\text { cavity. Under light pressure, } \\
\text { sperm could be expelled. In more } \\
\text { advanced conditions, sperm } \\
\text { escapes freely. }\end{array}$ \\
\hline $4 a$ & SPENT & $\begin{array}{l}\text { Reddish ovary shrunk to about } \\
1 / 2 \text { length of body cavity. Flaccid } \\
\text { ovaric walls; ovary may contain } \\
\text { remnants of disintegrating opaque } \\
\text { and/or translucent eggs. }\end{array}$ & $\begin{array}{l}\text { Bloodshot and flabby testis } \\
\text { shrunk to about } 1 / 2 \text { length of } \\
\text { body cavity. }\end{array}$ \\
\hline $4 b$ & RESTING & $\begin{array}{l}\text { Pinkish and translucent ovary; length } \\
\text { about } 1 / 3 \text { of body cavity. Eggs not } \\
\text { visible to naked eye. }\end{array}$ & $\begin{array}{l}\text { Whitish/pinkish testis, more or } \\
\text { less symmetrical; length about } \\
1 / 3 \text { of body cavity. }\end{array}$ \\
\hline
\end{tabular}

Source: MEDITS, 2017; see also Appendix G.1 of the DCRF manual (GFCM, 2018a). 
Annex 8.2. Maturity scale for cephalopods

\begin{tabular}{|c|c|c|c|}
\hline \multicolumn{4}{|c|}{$\begin{array}{l}\text { Annex 8.2. Maturity scale } \\
\text { (cephalopods) }\end{array}$} \\
\hline Stages & Maturation state & Reproductive apparatus aspect & Sex \\
\hline 0 & UNDETERMINED & Sex not distinguished by naked eye. Sex undetermined. & $\mathrm{U}$ \\
\hline \multirow[t]{2}{*}{1} & \multirow[t]{2}{*}{ IMMATURE-VIRGIN } & $\begin{array}{l}\text { Small and translucent nidamental glands (NG)/oviducal } \\
\text { glands (OG). Ovary is semi-transparent, stringy and } \\
\text { lacking granular structure. Small semi-transparent NG/ } \\
\text { OG. Oviduct meander not visible. Total absence of } \\
\text { spermatophores. }\end{array}$ & $\mathrm{F}$ \\
\hline & & $\begin{array}{l}\text { Testis small. Spermatophoric complex (SC) semi- } \\
\text { transparent; vas deferens not visible. Penis appears as a } \\
\text { small prominence of SC. }\end{array}$ & M \\
\hline \multirow[t]{2}{*}{$2 a$} & \multirow[t]{2}{*}{ DEVELOPING } & $\begin{array}{l}\text { NG/OG enlarged. NG covering some internal organs. } \\
\text { Whitish ovary with granular structure clearly visible, not } \\
\text { reaching the posterior half of the mantle cavity. Oviduct } \\
\text { meander clearly visible. Eggs very small. Absence of } \\
\text { spermatophores. }\end{array}$ & $\mathrm{F}$ \\
\hline & & $\begin{array}{l}\text { Enlarged testis with structure not clearly visible. Vas } \\
\text { deferens is whitish or white and the spermatophoric } \\
\text { organ has a white streak. }\end{array}$ & M \\
\hline \multirow{2}{*}{$2 b$} & \multirow{2}{*}{ MATURING } & $\begin{array}{l}\text { Large NG covering the viscera below. Ovary occupies } \\
\text { the whole posterior half of mantle cavity, containing } \\
\text { reticulated, tightly packed oocytes of all sizes and } \\
\text { probably a few ripe ova at its proximal part. Oviducts } \\
\text { fully developed, but empty. Maturing eggs visible to } \\
\text { naked eye. Few spermatophores. }\end{array}$ & $\mathrm{F}$ \\
\hline & & $\begin{array}{l}\text { Vas deferens is white, meandering, enlarged. Needham's } \\
\text { sac with structure less whitish particles inside. Normally, } \\
\text { the Needham's sac is without functional spermatophores, } \\
\text { but sometimes some immature/abortive ones could occur. } \\
\text { Testis tight, crispy, with visible structure. }\end{array}$ & M \\
\hline \multirow[t]{2}{*}{$3 a$} & \multirow[t]{2}{*}{ MATURE } & $\begin{array}{l}\text { Large NG as previously. Ovary containing higher } \\
\text { percentage of large reticulated eggs and some large } \\
\text { ripe ova with smooth surface. In Teuthoidea, ripe } \\
\text { ova in oviducts. Eggs medium and large, and visible } \\
\text { both in oviducts and in the ovary. Well-developed } \\
\text { spermatophores. }\end{array}$ & $\mathrm{F}$ \\
\hline & & $\begin{array}{l}\text { Testis as before. Spermatophores packed in the } \\
\text { Needham's sac. }\end{array}$ & $\mathrm{M}$ \\
\hline \multirow[t]{2}{*}{$3 b$} & \multirow[t]{2}{*}{ SPENT } & $\begin{array}{l}\text { NG/OG large but soft and running. Ovary shrunk and } \\
\text { flaccid, with only immature oocytes attached to the } \\
\text { central tissue and a few loose large ova in the coelom. In } \\
\text { Teuthoidea, oviduct may contain some mature ova, but } \\
\text { they are no longer packed. }\end{array}$ & $\mathrm{F}$ \\
\hline & & $\begin{array}{l}\text { Disintegrating spermatophores in the Needham's sac and } \\
\text { the penis. }\end{array}$ & $\mathrm{M}$ \\
\hline
\end{tabular}

Source: MEDITS, 2017; see also Appendix G.2 of the DCRF manual (GFCM, 2018a). 


\section{Annex 8.3. Maturity scale for crustaceans}

\begin{tabular}{|c|c|c|c|c|}
\hline \multicolumn{5}{|c|}{$\begin{array}{c}\text { Annex 8.3. Maturity scale } \\
\text { (crustaceans) }\end{array}$} \\
\hline Stages & Sex & Maturation state & Reproductive apparatus aspect & Colouring of fresh ovary \\
\hline \multirow{2}{*}{1} & $\mathrm{~F}$ & \multirow{2}{*}{ IMMATURE-VIRGIN* } & $\begin{array}{l}\text { The ovary is barely visible. After dissection of } \\
\text { the tegument, the ovary is small, and lobes are } \\
\text { flaccid, stringy and poorly developed. } \\
\text { A. foliacea and } A \text {. antennatus: have no } \\
\text { spermatophores on thelycum. }\end{array}$ & \multirow{2}{*}{ Whitish or translucid } \\
\hline & M & & $\begin{array}{l}\text { The petasma is not highly visible and there are } \\
\text { no spermatic masses (emi-spermatophores) on } \\
\text { the seminal ampullae located on the side of } \\
\text { the fifth pair of pereiopods. A. foliacea and } \\
\text { A. antennatus have a long rostrum. }\end{array}$ & \\
\hline \multirow{4}{*}{$2 a$} & \multirow{3}{*}{$\mathrm{F}$} & \multirow{4}{*}{$\begin{array}{l}\text { VIRGIN } \\
\text { DEVELOPING* }\end{array}$} & \multirow{3}{*}{$\begin{array}{l}\text { The ovary status is developing. Cephalic and } \\
\text { lateral lobes are small but discernible to the } \\
\text { naked eye. The abdominal extensions are thin } \\
\text { and slightly visible. }\end{array}$} & $\begin{array}{l}\text { A. foliacea: flesh- } \\
\text { coloured; }\end{array}$ \\
\hline & & & & $\begin{array}{l}\text { A. antennatus: ivory- } \\
\text { coloured with orange } \\
\text { pink-violet dotting; }\end{array}$ \\
\hline & & & & $\begin{array}{l}\text { N. norvegicus: cream } \\
\text { coloured; }\end{array}$ \\
\hline & M & & $\begin{array}{l}\text { The petasma is visible and nearly or completely } \\
\text { joined, but there are no spermatic masses in } \\
\text { the seminar amplullae. A. foliacea and } \\
\text { A. antennatus: long or intermediate rostrum. }\end{array}$ & $\begin{array}{l}\text { P. longirostris: cream- } \\
\text { orange coloured. }\end{array}$ \\
\hline \multirow{4}{*}{$2 b$} & \multirow{3}{*}{$\mathrm{F}$} & \multirow{4}{*}{ RECOVERING* } & \multirow{3}{*}{$\begin{array}{l}\text { The ovary is starting a new reproductive cycle. } \\
\text { The cephalic and lateral lobes are small but } \\
\text { discernible to the naked eye. The abdominal } \\
\text { extensions are thin and slightly visible. } \\
\text { Occasionally, there are spermatophores in } \\
\text { A. foliacea and } A \text {. antennatus. }\end{array}$} & $\begin{array}{l}\text { A. foliacea: flesh- } \\
\text { coloured; }\end{array}$ \\
\hline & & & & $\begin{array}{l}\text { A. antennatus: ivory- } \\
\text { coloured with orange } \\
\text { pink-violet dotting; }\end{array}$ \\
\hline & & & & $\begin{array}{l}\text { N. norvegicus: cream } \\
\text { coloured; }\end{array}$ \\
\hline & M & & $\begin{array}{l}\text { The petasma appears completely joined but } \\
\text { there are no spermatic masses in the seminar } \\
\text { amplullae. } A \text {. foliacea and } A \text {. antennatus: short } \\
\text { rostrum. }\end{array}$ & $\begin{array}{l}\text { P. longirostris: cream- } \\
\text { orange coloured. }\end{array}$ \\
\hline \multirow{4}{*}{$2 c$} & \multirow{3}{*}{$\mathrm{F}$} & \multirow{4}{*}{$\begin{array}{l}\text { MATURING or } \\
\text { ALMOST MATURE }\end{array}$} & \multirow{3}{*}{$\begin{array}{l}\text { The ovary is developed and occupies the dorsal } \\
\text { portion almost entirely. The cephalic and } \\
\text { lateral lobes are highly developed and have a } \\
\text { turgid consistence. }\end{array}$} & $\begin{array}{l}\text { A. foliacea: light and } \\
\text { dark grey; }\end{array}$ \\
\hline & & & & A. antennatus: lilla; \\
\hline & & & & $\begin{array}{l}\text { N. norvegicus: light } \\
\text { green; }\end{array}$ \\
\hline & $\mathrm{M}$ & & - & $\begin{array}{l}P . \text { longirostris: light } \\
\text { green or grey green. }\end{array}$ \\
\hline \multirow{4}{*}{$2 d$} & \multirow{3}{*}{$\mathrm{F}$} & \multirow{4}{*}{ MATURE } & \multirow{3}{*}{$\begin{array}{l}\text { The turgid ovary extends to the whole dorsal } \\
\text { portion, covering the organs below. The } \\
\text { lobes and extensions are well developed; in } \\
\text { particular, the abdominal extensions are highly } \\
\text { visible. The oocytes are well developed. }\end{array}$} & A. foliacea: black; \\
\hline & & & & A. antennatus: violet; \\
\hline & & & & $\begin{array}{l}\text { N. norvegicus: dark } \\
\text { green; }\end{array}$ \\
\hline & M & & $\begin{array}{l}\text { The petasma is perfectly visible and completely } \\
\text { joined. There is a spermatic mass in the } \\
\text { seminar ampullae. A. foliacea and } \\
\text { A. antennatus have a small rostrum. }\end{array}$ & $\begin{array}{l}P . \text { longirostris: bright } \\
\text { green or olive green. }\end{array}$ \\
\hline $2 \mathrm{e}$ & $\mathrm{F}$ & RESTING ADULT* & $\begin{array}{l}\text { It has a resting ovary. Spermatophores are } \\
\text { present in } A \text {. foliacea and } A \text {. antennatus. }\end{array}$ & Uncoloured \\
\hline 3 & $\mathrm{~F}$ & BERRIED & Eggs are present on pleopods. & N. norvegicus \\
\hline
\end{tabular}

*these stages can be easily confused one with another.

Source: MEDITS, 2017. 
Annex 8.4. Maturity scale for oviparous elasmobranchs

\begin{tabular}{|c|c|c|c|}
\hline \multicolumn{4}{|c|}{$\begin{array}{l}\text { Annex 8.4. Maturity scale } \\
\text { (oviparous elasmobranchs) }\end{array}$} \\
\hline Stage & Sex & Maturation state & Gonad aspect \\
\hline \multirow{2}{*}{1} & $\mathrm{~F}$ & \multirow{2}{*}{ IMMATURE VIRGIN } & $\begin{array}{l}\text { The ovary with small isodiametric eggs is barely discernible. } \\
\text { The distal part of oviducts is thick-walled and whitish. The } \\
\text { nidamental glands are less evident. }\end{array}$ \\
\hline & M & & $\begin{array}{l}\text { The claspers are small and flaccid, and do not reach the } \\
\text { posterior edge of the pelvic fins. The sperm ducts are not } \\
\text { discernible. The testis is small and narrow. }\end{array}$ \\
\hline \multirow{2}{*}{2} & $\mathrm{~F}$ & \multirow{2}{*}{ MATURING* } & $\begin{array}{l}\text { The whitish and/or a few yellow maturing eggs are visible } \\
\text { in the ovary. The distal part of the oviducts (uterus) is well } \\
\text { developed but empty. The nidamental glands are small. }\end{array}$ \\
\hline & $M$ & & $\begin{array}{l}\text { The claspers are larger, but the skeleton is still flexible. They } \\
\text { extend to the posterior edge of the pelvic fins. Sperm ducts } \\
\text { are well developed and eventually begin to meander. }\end{array}$ \\
\hline \multirow[b]{2}{*}{$3 a$} & $\mathrm{~F}$ & \multirow[b]{2}{*}{ MATURE } & $\begin{array}{l}\text { The ovary contains yellow eggs (large yolk eggs). The } \\
\text { nidamental glands are enlarged, and oviducts are distended. }\end{array}$ \\
\hline & M & & $\begin{array}{l}\text { The claspers extend well beyond the posterior edge of the } \\
\text { pelvic fin, and their internal structure is generally hard and } \\
\text { ossified. The testis is greatly enlarged. The sperm ducts } \\
\text { meander over almost their entire length. }\end{array}$ \\
\hline \multirow{2}{*}{$3 b$} & $\mathrm{~F}$ & \multirow{2}{*}{ MATURE/EXTRUDING-ACTIVE } & $\begin{array}{l}\text { The ovary walls are transparent. Oocytes are of different } \\
\text { sizes, white or yellow. The nidamental glands are large. The } \\
\text { egg cases are more or less formed in the oviducts (extruding } \\
\text { stage). }\end{array}$ \\
\hline & $M$ & & $\begin{array}{l}\text { The claspers are longer than the tips of the posterior } \\
\text { pelvic fin lobes; the skeleton has hardened and pointed } \\
\text { axial cartilages. The sperm ducts are large. Sperm flows on } \\
\text { pressure from the cloaca (active stage). }\end{array}$ \\
\hline \multirow[t]{2}{*}{$4 a$} & $\mathrm{~F}$ & \multirow{2}{*}{ RESTING } & $\begin{array}{l}\text { The ovary walls are transparent. The oocytes are of different } \\
\text { sizes, white or yellow. The oviducts appear very enlarged, } \\
\text { collapsed and empty. The diameter of the nidamental glands } \\
\text { is reducing. }\end{array}$ \\
\hline & M & & $\begin{array}{l}\text { The claspers are longer than the tips of the posterior pelvic } \\
\text { fin lobes; the axial cartilages is still hardened. The sperm } \\
\text { ducts are empty and flaccid. }\end{array}$ \\
\hline $4 \mathrm{~b}$ & $\mathrm{~F}$ & REGENERATING* & $\begin{array}{l}\text { The ovary is full of small follicles similar to stage } 2 \text {. The } \\
\text { oviducal glands and uterus are enlarged. }\end{array}$ \\
\hline
\end{tabular}

*these stages can be easily confused one with another. Source: MEDITS, 2017. 
Annex 8.5. Maturity scale for viviparous elasmobranchs

\begin{tabular}{|c|c|c|c|c|}
\hline \multicolumn{5}{|c|}{$\begin{array}{l}\text { Annex 8.5. Maturity scale } \\
\text { (viviparous elasmobranchs) }\end{array}$} \\
\hline Stage & Sex & Maturation state & Maturity & Gonad aspect \\
\hline \multirow{2}{*}{1} & $\mathrm{~F}$ & \multirow{2}{*}{ IMMATURE } & \multirow{2}{*}{ IMMATURE } & $\begin{array}{l}\text { The ovary is barely visible or small and whitish; } \\
\text { the ovarian follicles are not visible. The oviducal } \\
\text { (nidamental) gland may be slightly visible. The } \\
\text { uterus is thread-like and narrow. }\end{array}$ \\
\hline & M & & & $\begin{array}{l}\text { The claspers are flexible and shorter than pelvic } \\
\text { fins. The testis is small (in rays, sometimes with } \\
\text { visible lobules). The sperm ducts are straight and } \\
\text { thread-like. }\end{array}$ \\
\hline \multirow[b]{2}{*}{2} & $\mathrm{~F}$ & \multirow[b]{2}{*}{ DEVELOPING } & \multirow[b]{2}{*}{ IMMATURE* } & $\begin{array}{l}\text { The ovary is enlarged with small follicles } \\
\text { (oocytes) of different sizes. Some relatively } \\
\text { larger yellow follicles may be present. The ovary } \\
\text { lacks atretic follicles. The oviducal gland and the } \\
\text { uterus are developing. }\end{array}$ \\
\hline & M & & & $\begin{array}{l}\text { The claspers are slightly more robust but still } \\
\text { flexible. They are as long as or longer than pelvic } \\
\text { fins. The testis is enlarged; in sharks, testis starts } \\
\text { to segment; in rays, lobules are clearly visible } \\
\text { but do not occupy the whole surface. The sperm } \\
\text { ducts are developing and beginning to meander. }\end{array}$ \\
\hline \multirow[b]{2}{*}{$3 a$} & $\mathrm{~F}$ & $\begin{array}{l}\text { CAPABLE of } \\
\text { REPRODUCING }\end{array}$ & \multirow[b]{2}{*}{ MATURE } & $\begin{array}{l}\text { The large ovary has enlarged yolk follicles that } \\
\text { are all roughly the same size, hence they can be } \\
\text { easily distinguished. The oviducal gland and the } \\
\text { uterus are developed. The uterus is not dilated } \\
\text { and does not contain yolky matter and embryos. }\end{array}$ \\
\hline & M & $\begin{array}{l}\text { CAPABLE of } \\
\text { REPRODUCING }\end{array}$ & & $\begin{array}{l}\text { The claspers are fully formed, and the skeleton is } \\
\text { hardened and rigid and is generally longer than } \\
\text { the pelvic fins. The testis is greatly enlarged; in } \\
\text { sharks, the testis is fully segmented; in rays, it is } \\
\text { filled with developed lobules. The sperm ducts } \\
\text { are tightly coiled and filled with sperm. }\end{array}$ \\
\hline \multirow[b]{2}{*}{$3 b$} & $\mathrm{~F}$ & $\begin{array}{l}\text { EARLY } \\
\text { PREGNANCY }\end{array}$ & MATERNAL & $\begin{array}{l}\text { The uteri are full and rounded with yolk content } \\
\text { (usually candle-shaped). In general, the segments } \\
\text { cannot be discernible, and embryos cannot be } \\
\text { observed. }\end{array}$ \\
\hline & M & $\begin{array}{l}\text { ACTIVELY } \\
\text { SPAWNING }\end{array}$ & MATURE & $\begin{array}{l}\text { The description is similar to stage } 3 a \text {, but with } \\
\text { clasper glands dilated, often swollen and reddish } \\
\text { (occasionally open). The sperm is often present } \\
\text { in the clasper grooves or glands. Under pressure, } \\
\text { sperm is observed flowing out of the cloaca or in } \\
\text { the sperm ducts. }\end{array}$ \\
\hline $3 c$ & $\mathrm{~F}$ & $\begin{array}{l}\text { MID- } \\
\text { PREGNANCY }\end{array}$ & MATERNAL & $\begin{array}{l}\text { The uteri are well filled and rounded, often with } \\
\text { visible segments. The embryos are always visible } \\
\text { and small, and with a relatively large yolk sac. }\end{array}$ \\
\hline $3 d$ & $\mathrm{~F}$ & $\begin{array}{l}\text { LATE } \\
\text { PREGNANCY }\end{array}$ & MATERNAL & $\begin{array}{l}\text { The embryos are fully formed; the yolk sacs are } \\
\text { reduced or absent. The embryos can be easily } \\
\text { measured and sexed. }\end{array}$ \\
\hline $4 a$ & $\mathrm{~F}$ & REGRESSING & MATURE & $\begin{array}{l}\text { The ovaries are shrunken without follicle } \\
\text { development and with atretic (degenerating) } \\
\text { follicles. The diameter of the oviducal glands } \\
\text { may be decreasing. The uterus appears much } \\
\text { enlarged, collapsed, empty and reddish. }\end{array}$ \\
\hline 4 & M & REGRESSING & MATURE & $\begin{array}{l}\text { The claspers are fully formed, similar to stage } \\
\text { 3. The testis and sperm ducts are shrunken and } \\
\text { flaccid. }\end{array}$ \\
\hline \multirow[b]{2}{*}{$4 b$} & \multirow[b]{2}{*}{$\mathrm{F}$} & REGENERATING & \multirow[b]{2}{*}{ MATURE* } & \multirow{2}{*}{$\begin{array}{l}\text { The ovary has small follicles at different stages } \\
\text { of development including atretic ones. The } \\
\text { uterus is enlarged with flaccid walls. The } \\
\text { oviducal gland is discernible. }\end{array}$} \\
\hline & & (mature) & & \\
\hline
\end{tabular}

*these stages can be easily confused one with another.

Source: MEDITS, 2017. 
Annex 8.6. Maturity scale for stomatopods

\begin{tabular}{|c|c|c|}
\hline \multicolumn{3}{|r|}{$\begin{array}{l}\text { Annex 8.6. Maturity scale } \\
\text { (stomatopods) }\end{array}$} \\
\hline Maturation state & Stages & Reproductive apparatus aspect \\
\hline Immature & 0 & Ovaries filamentous and hyaline; $6^{\text {th }}-8^{\text {th }}$ sternites hyaline. \\
\hline Quiescent & 1 & $\begin{array}{l}\text { Filamentous ovaries with evident brown dots (chromatophores), } \\
6^{\text {th }}-8^{\text {th }} \text { sternites hyaline. }\end{array}$ \\
\hline Early Maturation & 2 & Narrow yellow ovaries, $6^{\text {th }}-8^{\text {th }}$ sternites whitish. \\
\hline Maturation & 3 & $\begin{array}{l}\text { Yellow ovaries extending up to half of abdomen width, not visible } \\
\text { through cutile on ventral side of telson, } 6^{\text {th }}-8^{\text {th }} \text { sternites white. }\end{array}$ \\
\hline Ripe & 4 & $\begin{array}{l}\text { Yellow ovaries extending over half abdominal width, visible through } \\
\text { cutile on ventral side of telson, } 6^{\text {th}}-8^{\text {th }} \text { sternites milky white. }\end{array}$ \\
\hline Spent & 5 & $\begin{array}{l}\text { Similar to quiescent ovaries, sometime with a few yellow dots, but } \\
6^{\text {th }}-8^{\text {th }} \text { sternites still white. }\end{array}$ \\
\hline
\end{tabular}

Note: see also Appendix G.5 of the DCRF manual (GFCM, 2018a). 


\section{ANNEX 9. SIX-PHASE MATURITY STAGES FOR ANCHOVIES AND SARDINES CAUGHT} IN PELAGIC SURVEYS

\begin{tabular}{|c|c|c|c|c|}
\hline \multicolumn{5}{|c|}{ Annex 9. Six-phase maturity stages for anchovies and sardines caught in pelagic surveys } \\
\hline Stage & Activity & Stage name & Female & Male \\
\hline 1 & \multirow{2}{*}{ Inactive } & Immature or resting & $\begin{array}{l}\text { Invisible or very small ovaries } \\
\text { (cord-shaped), translucent or } \\
\text { slightly coloured (when resting). }\end{array}$ & $\begin{array}{l}\text { Very small testis, translucent. } \\
\text { Sex is very difficult to identify; } \\
\text { small testis, colour orange-red } \\
\text { (when resting). }\end{array}$ \\
\hline 2 & & Developing & $\begin{array}{l}\text { Wider ovaries occupying } 1 / 4 \text { to } \\
1 / 3 \text { of body cavity; pinkish or } \\
\text { yellow colour. Visible oocytes } \\
\text { are not present. }\end{array}$ & $\begin{array}{l}\text { The testis occupy approximately } \\
1 / 3 \text { of the abdominal cavity. } \\
\text { White-greyish colour. }\end{array}$ \\
\hline 3 & \multirow[b]{2}{*}{ Active } & Imminent spawning & $\begin{array}{l}\text { Ovaries occupying } 3 / 4 \text { to almost } \\
\text { fitting body cavity; opaque } \\
\text { with yellow or orange colour. } \\
\text { Opaque oocytes are visible. }\end{array}$ & $\begin{array}{l}\text { Whitish to creamy testis about } \\
2 / 3 \text { of the body cavity. Under } \\
\text { light pressure, sperm is not } \\
\text { expelled. }\end{array}$ \\
\hline 4 & & Spawning & $\begin{array}{l}\text { Large ovaries occupying the full } \\
\text { body cavity; fully or partially } \\
\text { translucent with gelatinous } \\
\text { aspect. Hyaline oocytes are } \\
\text { visible. }\end{array}$ & $\begin{array}{l}\text { Whitish-creamy soft testis } \\
\text { occupy the full body cavity. } \\
\text { Under light pressure, sperm is } \\
\text { expelled freely. }\end{array}$ \\
\hline 5 & & Partial post-spawning & $\begin{array}{l}\text { Size from } 1 / 2 \text { to } 3 / 4 \text { of } \\
\text { abdominal cavity; non-turgid } \\
\text { ovaries with haemorrhagic } \\
\text { zones. Blood coloured. }\end{array}$ & $\begin{array}{l}\text { Deflated testicles occupy up } \\
\text { to } 2 / 3 \text { of the body cavity. } \\
\text { Brownish/reddish colour. }\end{array}$ \\
\hline 6 & Inactive & Spent & $\begin{array}{l}\text { Reddish ovary shrunken. Size } \\
\text { less than } 2 / 3 \text { of abdominal } \\
\text { cavity. Flaccid ovary. Some small } \\
\text { opaque oocyte. }\end{array}$ & $\begin{array}{l}\text { Flaccid and thin testicles with } \\
\text { haemorrhagic aspect. }\end{array}$ \\
\hline
\end{tabular}

The following six-phase maturity scale should be used for sardine (Sardina pilchardus) and anchovy (Engraulis encrasicolus), captured during pelagic surveys (ICES, 2008).

Source: ICES, 2008. 
ANNEX 10. MATURITY SCALE CONVERSION TABLE FOR ANCHOVY (ENGRAULIS
ENCRASICOLUS) AND SARDINE (SARDINA PILCHARDUS)

\begin{tabular}{|c|c|c|c|c|}
\hline \multicolumn{5}{|c|}{ Annex 10. Maturity scales conversion table for anchovies and sardines } \\
\hline \multirow[b]{2}{*}{ Status } & \multicolumn{2}{|c|}{ Pelagic survey maturity scale } & \multicolumn{2}{|c|}{ DCRF maturity scale } \\
\hline & Stage & Name of stage & Stage & Name of stage \\
\hline & 0 & Undetermined & 0 & Undetermined \\
\hline \multirow{3}{*}{ Inactive } & \multirow{2}{*}{1} & \multirow{2}{*}{ Immature or resting } & 1 & Immature-virgin \\
\hline & & & $2 a$ & Virgin-developing \\
\hline & 2 & Developing & $2 b$ & Recovering \\
\hline \multirow{3}{*}{ Active } & 3 & Imminent spawning & $2 c$ & Maturing \\
\hline & 4 & Spawning & 3 & Mature/spawner \\
\hline & 5 & Partial post-spawning & $4 a$ & Spent \\
\hline Inactive & 6 & Spent & $4 b$ & Resting \\
\hline
\end{tabular}

For the purpose of the DCRF only (GFCM, 2018a), maturity data collected following the six-phase maturity scale (as in Annex 9) should be then converted and reported according to DCRF requirements (Recommendation GFCM/41/2017/6) using the conversion table below (ICES, 2008). 
ANNEX 11. REPORTING TEMPLATES FOR BOTTOM AND BEAM TRAWL DEMERSAL SURVEYS

Annex 11.1. Demersal surveys: fishing haul data (TA file)

\begin{tabular}{|l|l|l|l|l|l|l|}
\hline \multicolumn{7}{|c|}{ Annex 11.1. Demersal surveys: fishing haul data } \\
\hline Type of file & Country & Area & Vessel & Gear & Rigging & Doors \\
\hline
\end{tabular}

Cont.

\begin{tabular}{|l|l|l|l|l|l|}
\hline Year & Month & Day & Haul number & $\begin{array}{l}\text { Codend } \\
\text { closing }\end{array}$ & $\begin{array}{l}\text { Part of the } \\
\text { codend }\end{array}$ \\
\hline
\end{tabular}

Cont.

\begin{tabular}{|l|l|l|l|l|l|}
\hline $\begin{array}{l}\text { Shooting } \\
\text { quadrant }\end{array}$ & $\begin{array}{l}\text { Shooting } \\
\text { latitude }\end{array}$ & $\begin{array}{l}\text { Shooting } \\
\text { longitude }\end{array}$ & $\begin{array}{l}\text { Shooting } \\
\text { depth }\end{array}$ & Hauling time & $\begin{array}{l}\text { Hauling } \\
\text { quadrant }\end{array}$ \\
\hline
\end{tabular}

Cont.

\begin{tabular}{|l|l|l|l|l|l|}
\hline $\begin{array}{l}\text { Hauling } \\
\text { longitude }\end{array}$ & $\begin{array}{l}\text { Hauling } \\
\text { depth }\end{array}$ & Haul duration & Validity & Course & $\begin{array}{l}\text { Recorded } \\
\text { species }\end{array}$ \\
\hline
\end{tabular}

Cont.

\begin{tabular}{|l|l|l|l|l|l|l|}
\hline $\begin{array}{l}\text { Vertical } \\
\text { opening }\end{array}$ & $\begin{array}{l}\text { Wing } \\
\text { opening }\end{array}$ & $\begin{array}{l}\text { Geometrical } \\
\text { precision }\end{array}$ & Bridle length & Warp length & $\begin{array}{l}\text { Warp } \\
\text { diameter }\end{array}$ \\
\hline
\end{tabular}

Cont.

\begin{tabular}{|c|l|l|l|l|l|l|}
\hline Observations & $\begin{array}{l}\text { Bottom } \\
\text { temperature } \\
\text { beginning }\end{array}$ & $\begin{array}{l}\text { Bottom } \\
\text { temperature } \\
\text { end }\end{array}$ & $\begin{array}{l}\text { Measuring } \\
\text { system }\end{array}$ & $\begin{array}{l}\text { Number of } \\
\text { the stratum }\end{array}$ & $\begin{array}{l}\text { Bottom } \\
\text { salinity } \\
\text { beginning }\end{array}$ \\
\hline
\end{tabular}

Cont.

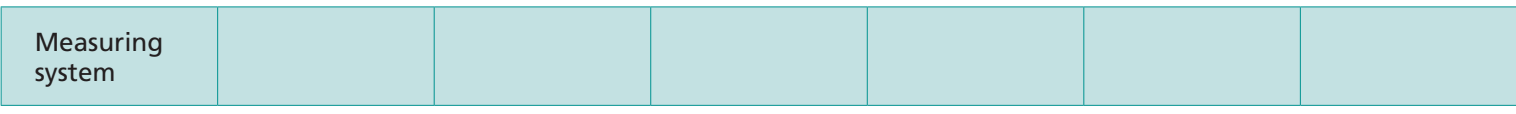

Note: to properly fill in the templates for bottom trawl demersal survey, see description in Section 1.6.

Source: MEDITS, 2017. 
Annex 11.2. Demersal surveys: catch data (TB file)

\begin{tabular}{|l|l|l|l|l|l|l|}
\hline \multicolumn{5}{|c|}{ Annex 11.2. Demersal surveys: catch data } \\
\hline \multirow{2}{*}{ Type of file } & Country & Area & Vessel & Year & Month & Day \\
\hline
\end{tabular}

Cont.

\begin{tabular}{|l|l|l|l|l|l|}
\hline Haul number & $\begin{array}{l}\text { Codend } \\
\text { closing }\end{array}$ & $\begin{array}{l}\text { Part of the } \\
\text { codend }\end{array}$ & $\begin{array}{l}\text { Faunistic } \\
\text { category }\end{array}$ & Genus & Species \\
\hline
\end{tabular}

Cont.

\begin{tabular}{|l|l|l|l|l|l|}
$\begin{array}{l}\text { Name of the } \\
\text { reference list }\end{array}$ & $\begin{array}{l}\text { Total weight } \\
\text { in the haul }\end{array}$ & $\begin{array}{l}\text { Total number } \\
\text { in the haul }\end{array}$ & $\begin{array}{l}\text { Number of } \\
\text { females }\end{array}$ & $\begin{array}{l}\text { Number of } \\
\text { males }\end{array}$ & $\begin{array}{l}\text { Number of } \\
\text { undetermined }\end{array}$ \\
\hline
\end{tabular}

Note: to properly fill in the templates for bottom trawl demersal survey, see description in Section 1.6. Source: MEDITS, 2017. 
Annex 11.3. Demersal surveys: biological data (TC file)

\begin{tabular}{|c|c|c|c|c|c|c|c|}
\hline \multicolumn{7}{|c|}{ Annex 11.3. Demersal survey: biological data by species per fishing haul } \\
\hline Type of file & Country & Area & Vessel & Year & Month & Day & Haul number \\
\hline
\end{tabular}

Cont.

\begin{tabular}{|l|l|l|l|l|l|l|}
\hline $\begin{array}{l}\text { Codend } \\
\text { closing }\end{array}$ & $\begin{array}{l}\text { Part } \\
\text { of the } \\
\text { codend }\end{array}$ & $\begin{array}{l}\text { Faunistic } \\
\text { category }\end{array}$ & Genus & Species & $\begin{array}{l}\text { Length } \\
\text { class code }\end{array}$ & $\begin{array}{l}\text { Weight of the } \\
\text { fraction }\end{array}$ \\
\hline
\end{tabular}

Cont.

\begin{tabular}{|l|l|l|l|l|l|l|}
\hline $\begin{array}{l}\text { Weight of } \\
\text { the sample } \\
\text { measured }\end{array}$ & Sex & $\begin{array}{l}\text { Number of } \\
\text { individuals } \\
\text { per sex } \\
\text { measured }\end{array}$ & $\begin{array}{l}\text { Length } \\
\text { class }\end{array}$ & Maturity & Matsub & $\begin{array}{l}\text { Number of } \\
\text { individuals in the } \\
\text { length class and } \\
\text { maturity stage }\end{array}$ \\
\hline
\end{tabular}

Note: to properly fill in the templates for bottom trawl demersal survey, see description in Section 1.6 . Source: MEDITS, 2017. 
Annex 11.4. Demersal surveys: individual biological data (TE file)

Annex 11.4. Demersal survey: individual biological data

\begin{tabular}{|l|l|l|l|l|l|l|l|l|}
\hline \multicolumn{7}{|c|}{ Annex 11.4. Demersal survey: individual biological data } \\
\hline Type of file & Country & Area & Vessel & Year & Month & Day & $\begin{array}{l}\text { Haul } \\
\text { number }\end{array}$ & $\begin{array}{l}\text { Faunistic } \\
\text { category }\end{array}$ \\
\hline
\end{tabular}

Cont.

\begin{tabular}{|l|l|l|l|l|l|l|}
\hline Genus & Species & $\begin{array}{l}\text { Length } \\
\text { class code }\end{array}$ & Sex & $\begin{array}{l}\text { Number } \\
\text { per sex } \\
\text { measured in } \\
\text { subsample } \\
\text { for otoliths }\end{array}$ & $\begin{array}{l}\text { Length } \\
\text { class }\end{array}$ & Maturity \\
\hline
\end{tabular}

Cont.

\begin{tabular}{|l|l|l|l|l|l|l|l|}
\hline $\begin{array}{l}\text { Individual } \\
\text { weight }\end{array}$ & $\begin{array}{l}\text { Number } \\
\text { per sex } \\
\text { measured in } \\
\text { subsample } \\
\text { for weight }\end{array}$ & $\begin{array}{l}\text { Otoliths } \\
\text { sampled }\end{array}$ & $\begin{array}{l}\text { Number } \\
\text { per sex } \\
\text { measured in } \\
\text { subsample } \\
\text { for ageing }\end{array}$ & Otoliths read & Age & $\begin{array}{l}\text { Otolith } \\
\text { code }\end{array}$ & $\begin{array}{l}\text { Record } \\
\text { number }\end{array}$ \\
\hline
\end{tabular}

Note: to properly fill in the templates for bottom trawl demersal survey, see description in Section 1.6. Source: MEDITS, 2017 
Annex 11.5. Demersal surveys: data on marine litter ( $T L$ file)

\begin{tabular}{|l|l|l|l|l|l|l|l|l|}
\hline \multicolumn{7}{|c|}{ Annex 11.5. Demersal survey: individual biological data } \\
\hline Type of file & Country & Area & Vessel & Year & Month & Day & $\begin{array}{l}\text { Haul } \\
\text { number }\end{array}$ & Litter category \\
\hline
\end{tabular}

Cont.

\begin{tabular}{|l|l|l|l|l|}
\hline $\begin{array}{l}\text { Litter } \\
\text { subcategory }\end{array}$ & $\begin{array}{l}\text { Total } \\
\text { weight } \\
\text { per haul }\end{array}$ & $\begin{array}{l}\text { Total } \\
\text { number } \\
\text { per haul }\end{array}$ & $\begin{array}{l}\text { Total weight in } \\
\text { the subcategory } \\
\text { per haul }\end{array}$ & $\begin{array}{l}\text { Total number in } \\
\text { the subcategory } \\
\text { per haul }\end{array}$ \\
\hline
\end{tabular}

Note: to properly fill in the templates for bottom trawl demersal survey, see description in Section 1.6.

Source: MEDITS, 2017. 
ANNEX 12. REPORTING TEMPLATES FOR PELAGIC ACOUSTIC SURVEYS

Annex 12.1. Pelagic acoustic surveys: length data

\begin{tabular}{|l|l|l|l|l|l|l|l|}
\hline \multicolumn{9}{|c|}{ Annex 12.1. Pelagic acoustic surveys: length data } \\
\hline \multirow{3}{*}{ Country } & Year & Start day & End day & $\begin{array}{l}\text { Start } \\
\text { month }\end{array}$ & $\begin{array}{l}\text { End } \\
\text { month }\end{array}$ & GSA & Survey \\
\hline
\end{tabular}

Cont.

\begin{tabular}{|l|l|l|l|l|l|l|l|}
\hline Variable* & Species & Sex & Unit & $\begin{array}{l}\text { Length } \\
\text { class 0 }\end{array}$ & $\begin{array}{l}\text { Length } \\
\text { class } 1\end{array}$ & $\begin{array}{l}\text { Length } \\
\text { class } 2\end{array}$ & Length class 3 \\
\hline
\end{tabular}

Cont.

\begin{tabular}{|l|l|l|l|l|l|l|l|}
\hline $\begin{array}{l}\text { Length } \\
\text { class } 4\end{array}$ & $\begin{array}{l}\text { Length } \\
\text { class 5 }\end{array}$ & $\begin{array}{l}\text { Length } \\
\text { class 6 }\end{array}$ & $\begin{array}{l}\text { Length } \\
\text { class 7 }\end{array}$ & $\begin{array}{l}\text { Length } \\
\text { class 8 }\end{array}$ & $\begin{array}{l}\text { Length } \\
\text { class 9 }\end{array}$ & $\begin{array}{l}\text { Length } \\
\text { class 10 }\end{array}$ & Length class 11 \\
\hline
\end{tabular}

Cont.

\begin{tabular}{|l|l|l|l|l|l|l|l|}
\hline $\begin{array}{l}\text { Length } \\
\text { class } 12\end{array}$ & $\begin{array}{l}\text { Length } \\
\text { class 13 }\end{array}$ & $\begin{array}{l}\text { Length } \\
\text { class 14 }\end{array}$ & $\begin{array}{l}\text { Length } \\
\text { class 15 }\end{array}$ & $\begin{array}{l}\text { Length } \\
\text { class 16 }\end{array}$ & $\begin{array}{l}\text { Length } \\
\text { class 17 }\end{array}$ & $\begin{array}{l}\text { Length } \\
\text { class } 18\end{array}$ & Length class 19 \\
\hline
\end{tabular}

Cont.

\begin{tabular}{|l|l|l|l|l|l|l|}
\hline $\begin{array}{l}\text { Length } \\
\text { class 20 }\end{array}$ & $\begin{array}{l}\text { Length } \\
\text { class 21 }\end{array}$ & $\begin{array}{l}\text { Length } \\
\text { class 22 }\end{array}$ & $\begin{array}{l}\text { Length } \\
\text { class 23 }\end{array}$ & $\begin{array}{l}\text { Length } \\
\text { class 24 }\end{array}$ & $\begin{array}{l}\text { Length } \\
\text { class 25 }\end{array}$ & $\begin{array}{l}\text { Length } \\
\text { class } \\
26 \text { plus }\end{array}$ \\
\hline
\end{tabular}

Note: for "variable" insert abundance or biomass. 
Annex 12.2. Pelagic acoustic surveys: age data

\begin{tabular}{|l|l|l|l|l|l|l|}
\hline \multicolumn{7}{|c|}{ Annex 12.2. Pelagic acoustic surveys: age data } \\
\hline Country & Year & Start day & End day & Start month & End month & Gsa \\
\hline
\end{tabular}

Cont.

\begin{tabular}{|l|l|l|l|l|l|l|}
\hline Survey & Variable* $^{*}$ & Species & Sex & Age group 0 & Age group 1 & Age group 2 \\
\hline
\end{tabular}

Cont.

\begin{tabular}{l|l|l|l|l|l|l} 
Age group 3 & Age group 4 & Age group 5 & Age group 6 & Age group 7 & Age group 8 & $\begin{array}{l}\text { Age group } \\
\text { 9plus }\end{array}$
\end{tabular}

Note: for "Variable" insert abundance or biomass. 
ANNEX 13. LIST OF VULNERABLE SPECIES

Annex 13.1. Vulnerable species included in Annex II and Annex III of the Barcelona Convention

List of vulnerable species included in Annex II (endangered or threatened species) and Annex III (species whose exploitation is regulated) of the Convention for the Protection of the Marine Environment and the Coastal Region of the Mediterranean (Barcelona Convention). The list also contains the amendments of Annexes II and III of the Convention's Protocol Concerning Specially Protected Areas and Biological Diversity in the Mediterranean (2012/510/EU: Council Decision of 10 July 2012, establishing the position to be adopted on behalf of the European Union with regard to the amendments, adopted by the $17^{\text {th }}$ Meeting of the Contracting Parties, Paris, France, 8-10 February 2012).

\begin{tabular}{|c|c|c|c|}
\hline Group of vulnerable species & Family & Species & Common name \\
\hline \multirow{18}{*}{ Cetaceans } & \multirow{4}{*}{ Balaenopteridae } & Balaenoptera acutorostrata & Common minke whale \\
\hline & & Balaenoptera borealis & Sei whale \\
\hline & & Balaenoptera physalus & Fin whale \\
\hline & & Megaptera novaeangliae & Humpback whale \\
\hline & Balaenidae & Eubalaena glacialis & North Atlantic right whale \\
\hline & \multirow{2}{*}{ Physeteridae } & Physeter macrocephalus & Sperm whale \\
\hline & & Kogia sima & Dwarf sperm whale \\
\hline & Phocoenidae & Phocoena phocoena & Harbour porpoise \\
\hline & \multirow{8}{*}{ Delphinidae } & Steno bredanensis & Rough-toothed dolphin \\
\hline & & Grampus griseus & Risso's dolphin \\
\hline & & Tursiops truncatus & Common bottlenose dolphin \\
\hline & & Stenella coeruleoalba & Striped dolphin \\
\hline & & Delphinus delphis & Common dolphin \\
\hline & & Pseudorca crassidens & False killer whale \\
\hline & & Globicephala melas & Long-finned pilot whale \\
\hline & & Orcinus orca & Killer whale \\
\hline & \multirow{2}{*}{ Ziphiidae } & Ziphius cavirostris & Cuvier's beaked whale \\
\hline & & Mesoplodon densirostris & Blainville's beaked whale \\
\hline Seals & Phocidae & Monachus monachus & Mediterranean monk seal \\
\hline
\end{tabular}




\begin{tabular}{|c|c|c|c|}
\hline Group of vulnerable species & Family & Species & Common name \\
\hline \multirow{29}{*}{ Sharks, Rays, Chimaeras } & Alopiidae & Alopias vulpinus & Common thresher \\
\hline & \multirow{3}{*}{ Carcharhinidae } & Carcharhinus plumbeus & Sandbar shark \\
\hline & & Carcharodon carcharias & Great white shark \\
\hline & & Prionace glauca & Blue shark \\
\hline & Centrophoridae & Centrophorus granulosus & Gulper shark \\
\hline & Cetorhinidae & Cetorhinus maximus & Basking shark \\
\hline & Gymnuridae & Gymnura altavela & Spiny butterfly ray \\
\hline & Hexanchidae & Heptranchias perlo & Sharpnose sevengill shark \\
\hline & \multirow{2}{*}{ Lamnidae } & Isurus oxyrinchus & Shortfin mako \\
\hline & & Lamna nasus & Porbeagle \\
\hline & Myliobatidae & Mobula mobular & Devil fish \\
\hline & \multirow{2}{*}{ Odontaspididae } & Carcharias taurus & Sand tiger \\
\hline & & Odontaspis ferox & Small-tooth sand tiger shark \\
\hline & Oxynotidae & Oxynotus centrina & Angular rough shark \\
\hline & \multirow{2}{*}{ Pristidae } & Pristis pectinata & Smalltooth sawfish \\
\hline & & Pristis pristis & Common sawfish \\
\hline & \multirow{4}{*}{ Rajidae } & Dipturus batis & Blue skate \\
\hline & & Leucoraja circularis & Sandy ray \\
\hline & & Leucoraja melitensis & Maltese skate \\
\hline & & Rostroraja alba & White skate \\
\hline & \multirow{2}{*}{ Rhinobatidae } & Rhinobatos cemiculus & Blackchin guitarfish \\
\hline & & Rhinobatos rhinobatos & Common guitarfish \\
\hline & \multirow{3}{*}{ Sphyrnidae } & Sphyrna lewini & Scalloped hammerhead \\
\hline & & Sphyrna mokarran & Great hammerhead \\
\hline & & Sphyrna zygaena & Smooth hammerhead \\
\hline & \multirow{3}{*}{ Squatinidae } & Squatina aculeata & Sawback angelshark \\
\hline & & Squatina oculata & Smoothback angelshark \\
\hline & & Squatina squatina & Angelshark \\
\hline & Triakidae & Galeorhinus galeus & School/Tope shark \\
\hline
\end{tabular}




\begin{tabular}{|c|c|c|c|}
\hline Group of vulnerable species & Family & Species & Common name \\
\hline \multirow{27}{*}{ Seabirds } & Falconidae & Falco eleonorae & Eleonora's falcon \\
\hline & \multirow{2}{*}{ Alcedinidae } & Ceryle rudis & Pied kingfisher \\
\hline & & Halcyon smyrnensis & White-throated kingfisher \\
\hline & \multirow{2}{*}{ Charadriidae } & Charadrius alexandrinus & Kentish plover \\
\hline & & Charadrius leschenaultii columbinus & Greater sand plover \\
\hline & \multirow[t]{2}{*}{ Hydrobatidae } & Hydrobates pelagicus melitensis* & $\begin{array}{l}\text { European storm-petrel } \\
\text { (Mediterranean) }\end{array}$ \\
\hline & & Hydrobates pelagicus* & European storm-petrel \\
\hline & \multirow{9}{*}{ Laridae } & Larus audouinii* & Audouin's gull \\
\hline & & Larus armenicus* & Armenian gull \\
\hline & & Larus genei* & Slender-billed gull \\
\hline & & Larus melanocephalus* & Mediterranean gull \\
\hline & & Sternula albifrons* & Little tern \\
\hline & & Thalasseus bengalensis* & Lesser crested tern \\
\hline & & Thalasseus sandvicensis* & Sandwich tern \\
\hline & & Hydroprogne caspia* & Caspian tern \\
\hline & & Gelochelidon nilotica* & Common Gull-billed tern \\
\hline & Pandionidae & Pandion haliaetus & Osprey \\
\hline & \multirow{2}{*}{ Pelecanidae } & Pelecanus crispus & Dalmatian pelican \\
\hline & & Pelecanus onocrotalus & Great white pelican \\
\hline & \multirow[t]{2}{*}{ Phalacrocoracidae } & Gulosus aristotelis desmarestii & $\begin{array}{l}\text { European shag } \\
\text { (Mediterranean) }\end{array}$ \\
\hline & & Microcarbo pygmaeus & Pygmy cormorant \\
\hline & Phoenicopteridae & Phoenicopterus roseus & Greater flamingo \\
\hline & \multirow{4}{*}{ Procellariidae } & Calonectris diomedea* & Scopoli's shearwater \\
\hline & & Calonectris borealis* & Cory's shearwater \\
\hline & & Puffinus yelkouan* & Yelkouan shearwater \\
\hline & & Puffinus mauretanicus* & Balearic shearwater \\
\hline & Scolopacidae & Numenius tenuirostris & Slender-billed curlew \\
\hline
\end{tabular}

* The only birds which can be considered as seabirds. The other species in the table are mentioned as "Aves" in Annex II of the Barcelona Convention. Some of them belong to the so-called water-bird or aquatic bird (e.g. birds that inhabit or depend on bodies of water or wetland areas). 


\begin{tabular}{|l|l|l|l|}
\hline Group of vulnerable species & Family & Species & Common name \\
\hline \multirow{2}{*}{ Sea turtles } & Caretta caretta & Loggerhead turtle \\
\cline { 3 - 4 } & \multirow{2}{*}{ Cheloniidae } & Chelonia mydas & Green turtle \\
\cline { 3 - 4 } & & Eretmochelys imbricata & Hawksbill Turtle \\
\cline { 3 - 4 } & & Lepidochelys kempii & Kemp's ridley sea turtle \\
\cline { 3 - 4 } & & Lepidochelys olivacea & Olive ridley sea turtle \\
\cline { 2 - 4 } & \multirow{2}{*}{ Dermochelyidae } & Dermochelys coriacea & Leatherback sea turtle \\
\cline { 2 - 4 } & Trionychidae & Trionyx triunguis & African softshell turtle \\
\hline
\end{tabular}




\section{Annex 13.2 Rare elasmobranch species}

This list reports elasmobranchs species that are included in the IUCN Red List of Threatened species (www.iucnredlist.org) or that are considered rare in the Mediterranean and the Black Sea (Bradai et al., 2012; IUCN, 2016). (https:/www.iucn.org/sites/dev/files/content/documents/ brochure_medredlist_sharks.pdf)

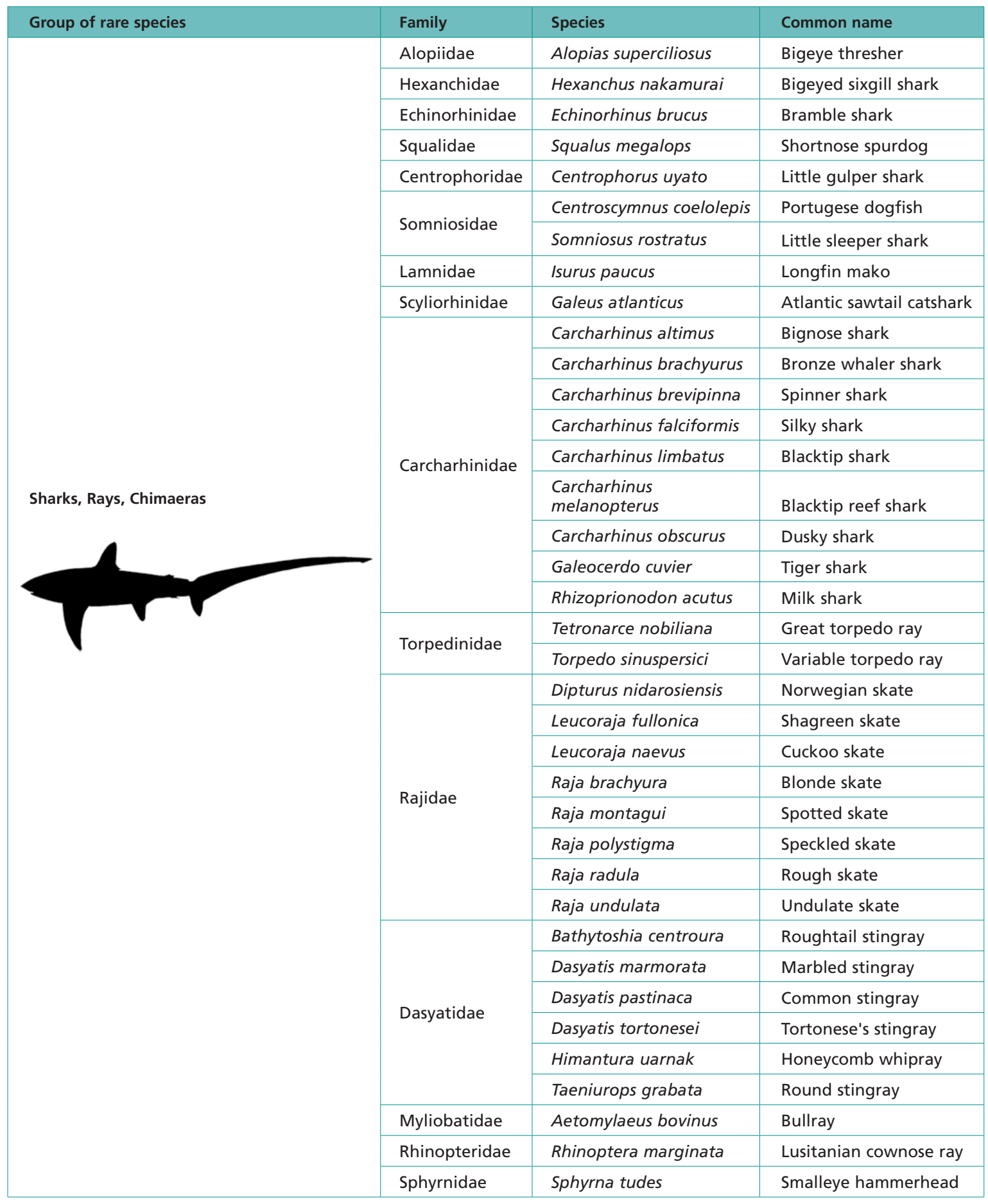


ANNEX 14. DATA ENTRY SHEET FOR VULNERABLE SPECIES

\begin{tabular}{|c|c|c|c|}
\hline \multicolumn{4}{|c|}{ Annex 14. Data on vulnerable species } \\
\hline \multicolumn{4}{|l|}{ Country } \\
\hline \multicolumn{4}{|l|}{ GSA } \\
\hline \multicolumn{4}{|l|}{ Date } \\
\hline Haul identification code & & & Notes \\
\hline \multicolumn{4}{|l|}{ Time of ending operation } \\
\hline \multicolumn{4}{|l|}{$\begin{array}{l}\text { Latitude (start and end) of the fishing } \\
\text { operation }\end{array}$} \\
\hline \multicolumn{4}{|l|}{$\begin{array}{l}\text { Longitude (start and end) of the fishing } \\
\text { operation }\end{array}$} \\
\hline \multicolumn{4}{|l|}{ Depth (in m) } \\
\hline \multicolumn{4}{|c|}{ Vulnerable species caught } \\
\hline & Species 1 & Species 2 & Notes \\
\hline \multicolumn{4}{|l|}{ Group of vulnerable species } \\
\hline \multicolumn{4}{|l|}{ Family* } \\
\hline \multicolumn{4}{|l|}{ Genus* } \\
\hline \multicolumn{4}{|l|}{ Species } \\
\hline \multicolumn{4}{|l|}{ Photo $(\mathrm{Y} / \mathrm{N}) *$} \\
\hline \multicolumn{4}{|l|}{ Total number of individual(s) caught } \\
\hline \multicolumn{4}{|l|}{ almost dead } \\
\hline \multicolumn{4}{|l|}{ not known } \\
\hline \multicolumn{4}{|l|}{ Condition at release* } \\
\hline alive & & & \\
\hline dead & & & \\
\hline almost dead & & & \\
\hline not known & & & \\
\hline
\end{tabular}

*If available.

$\sqrt{ }$ Data should be reported by species or by genus and/or family if the detailed information by species is not available.

$\sqrt{ }$ This template could be duplicated if several vulnerable species are caught during the same fishing haul.

Instructions:

- Survey: insert the name of the survey.

- GSA: insert the code of the geographical subarea (GSA) as in annex 1.

- Haul identification code: insert the identification code that has been assigned to the identified fishing haul (as in annex 3.1).

- Species: insert the scientific name of the identified species (as in annex 13).

- Latitude (start and end) of fishing operation: insert the latitude at the beginning and at the end of each fishing operation (e.g fishing hauls); data should be inserted in degrees, minutes and seconds (e.g. $40^{\circ} 51^{\prime} 59^{\prime \prime} \mathrm{N}$ ).

- Longitude (start and end) of fishing operation: insert the longitude at the beginning and at the end of each fishing operation (e.g. fishing hauls); data should be inserted in degrees, minutes and seconds (e.g. 124 $4^{\circ} 58^{\prime \prime} \mathrm{W}$ ).

- Depth (in $\mathrm{m}$ ): insert the depth in metres $(\mathrm{m})$ of the fishing haul.

- Photo $(\mathrm{Y} / \mathrm{N})$ : insert "yes" $(\mathrm{Y})$ or "no" $(\mathrm{N})$ if a photo of the specimen has been taken and, if "yes", assign an identification code to the photo.

- Total weight of individual(s) caught: whenever possible, for each group of vulnerable species caught, report the total weight in kilograms of the individual(s) caught, or insert an estimate.

- Condition at capture and condition at release: for each species, indicate the number of individuals that has been caught and released alive, dead, almost dead, or indicate that the state is not known. 
ANNEX 15. DATA ENTRY SHEET FOR MARINE MACRO-LITTER

\begin{tabular}{|c|c|c|c|}
\hline \multicolumn{4}{|c|}{ Annex 15. Data on marine macro-litter } \\
\hline \multicolumn{4}{|l|}{ Country } \\
\hline \multicolumn{4}{|l|}{ GSA } \\
\hline \multicolumn{4}{|l|}{ Survey } \\
\hline \multicolumn{4}{|l|}{ Date } \\
\hline Haul identification code & & & Notes \\
\hline \multicolumn{4}{|c|}{ Total quantity of marine litter $(\mathrm{kg})$} \\
\hline \multicolumn{4}{|c|}{ Percentage $(\%)$ of marine litter in the catch } \\
\hline Marine litter composition* & kg & $\%$ & Notes \\
\hline \multicolumn{4}{|l|}{ Plastic } \\
\hline \multicolumn{4}{|l|}{ Rubber } \\
\hline \multicolumn{4}{|l|}{ Fishing gear } \\
\hline \multicolumn{4}{|l|}{ Metal } \\
\hline \multicolumn{4}{|l|}{ Glass } \\
\hline \multicolumn{4}{|l|}{ Ceramic } \\
\hline \multicolumn{4}{|l|}{ Cloth } \\
\hline \multicolumn{4}{|l|}{ Wood processed } \\
\hline \multicolumn{4}{|l|}{ Other (please specify) } \\
\hline \multicolumn{4}{|l|}{ Comments: } \\
\hline
\end{tabular}

*If available.

Instructions:

- Survey: insert the name of the survey.

- GSA: insert the code of the geographical subarea (GSA) as in annex 1.

- Haul identification code: insert the identification code that has been assigned to the identified fishing haul (as in annex 3.1)

- Total quantity of marine litter (kg): insert the total weight in kilograms (or an estimate) of marine litter taken during a single fishing haul.

- Percentage (\%) of marine litter in the catch: insert the total marine litter fraction (in percentage) accumulated during a single fishing haul.

- Marine litter composition*: whenever possible, insert the weight (or an estimate) in kilograms $(\mathrm{kg})$ and the percentage of the different items contributing to the marine litter composition during a single fishing haul. 
ANNEX 16. DATA ENTRY SHEET FOR MACROBENTHOS

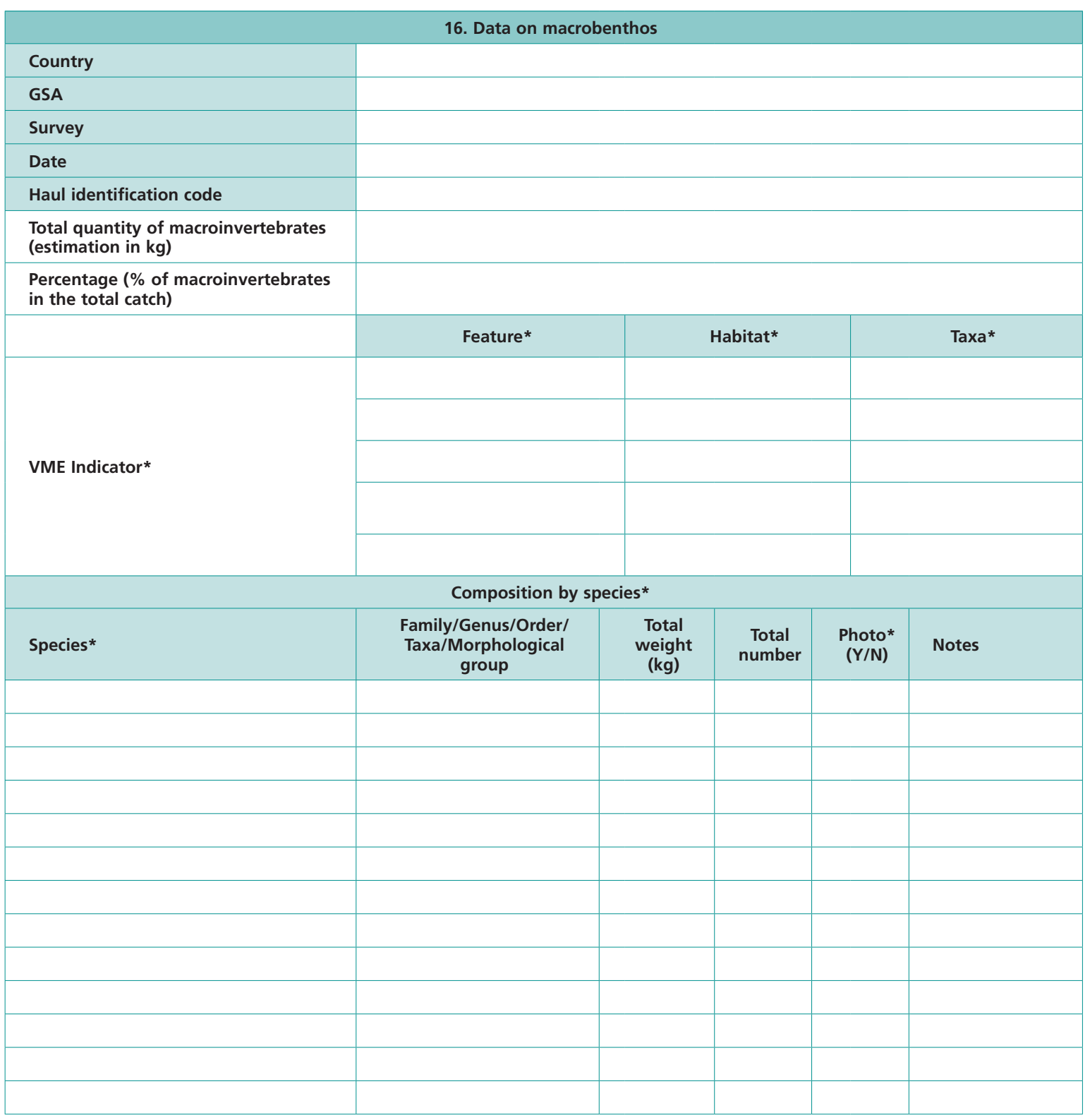

* If available.

Instructions:

- Survey: insert the name of the survey.

- GSA: insert the code of the geographical subarea (GSA) as in annex 1.

- Haul identification code: Insert the identification code which has been assigned to the identified fishing haul (as in Annex 3.1).

- Total quantity of macroinvertebrates (estimation in $\mathbf{k g}$ ): insert the total weight (or an estimate) of macroinvertebrates (macrobenthos) in kilograms taken during the same fishing trip or fishing operation.

- Percentage of macroinvertebrates in the total catch (\%): insert the total macroinvertebrates fraction (in percentage) cumulated during a single fishing haul.

- VME indicator (feature, habitat, taxa): if possible, record this information for each fishing haul (please refer to Box 4 in Section 4.1 ).

- Composition by species: whenever possible, insert the name of the macrobenthic species. When the specimens cannot be identified at the species level, the genus, family, order or taxa should be indicated. In cases where species identification is not possible (especially for sessile taxa), organisms can be assigned to morphological groups according to their growth form (e.g. massive, tubular, globular, arborescent, stalked, fan-shaped, lollipop-shaped, cup-shaped) combined with information about their colour, consistency (e.g. hard/soft) and photographic documentation.

- Total weight (kg): insert the total weight in kilograms (or an estimate) for each identified species of benthic marine macroinvertebrates caught during the same fishing trip or fishing operation.

- Total number: insert the total number (or an estimate) for each identified species of benthic marine macroinvertebrates caught during the same fishing haul.

- Photo $(\mathrm{Y} / \mathrm{N})$ : Insert "yes" or "no" if a photo of the specimen has been taken, and if "yes", assign an identification code to the photo. 
ANNEX 17. SCHEME OF THE RAPIDO TRAWL

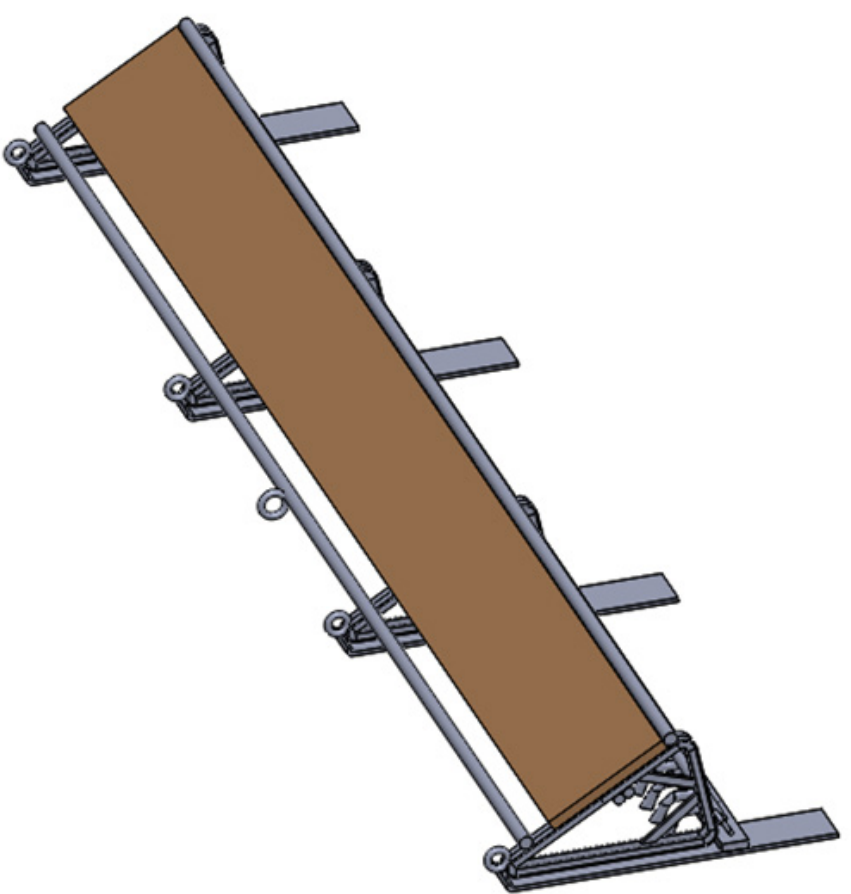

a) Rapido trawl frame upside (author: Emilio Notti)

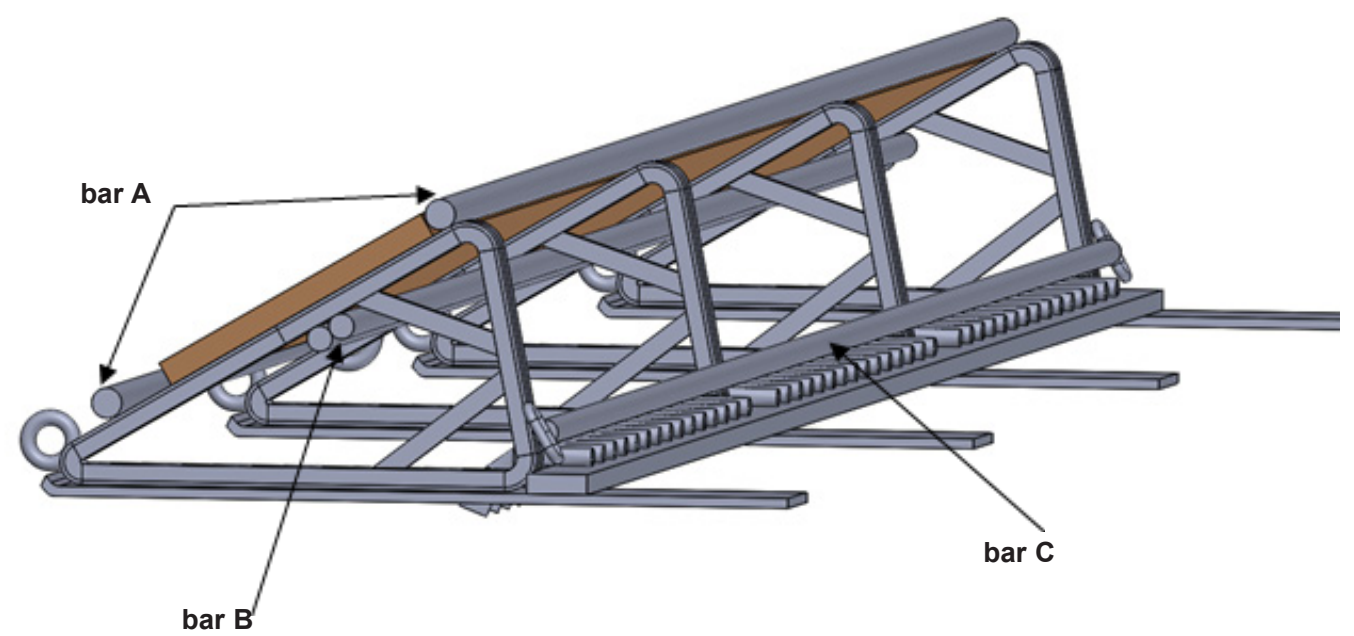

b) Rapido trawl frame lateral-back side. Bottom surface of central sledges $1 \mathrm{~cm}$ over the lateral sledges (author: Emilio Notti) 
$3600 \mathrm{~mm}$

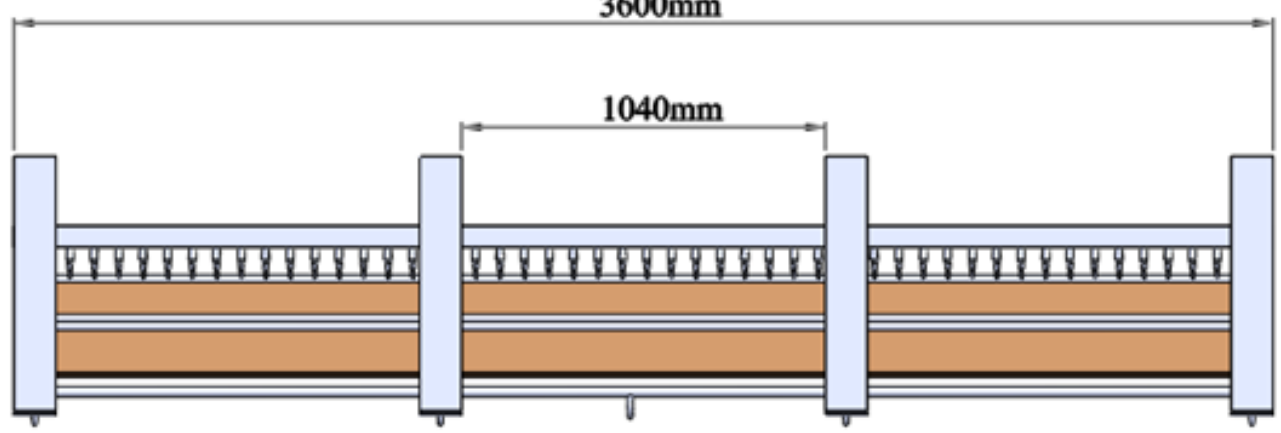

c) Rapido trawl frame bottom side (author: Emilio Notti)

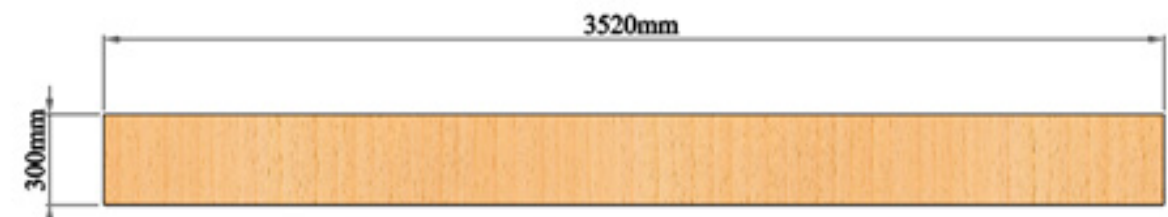

d) Rapido trawl deflector (20 mm height) (author: Emilio Notti)

$3520 \mathrm{~mm}$

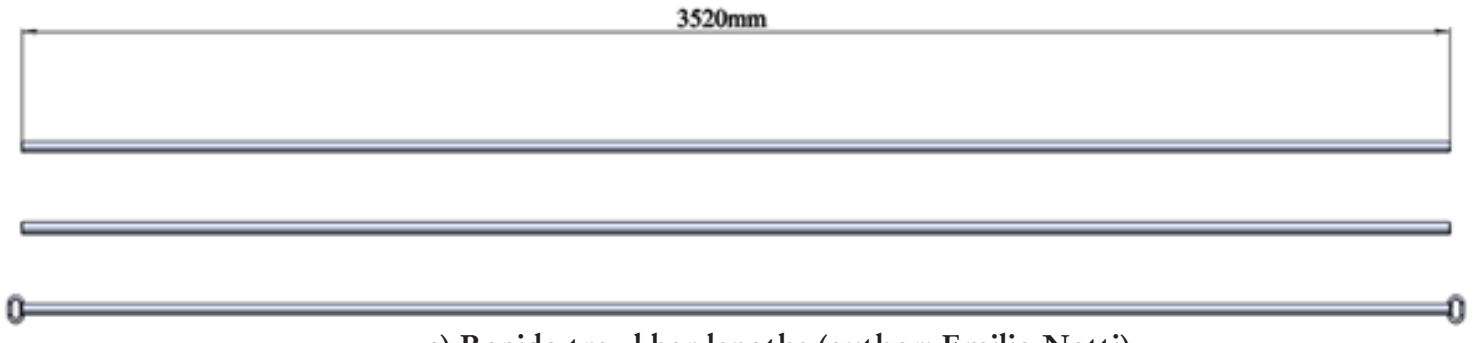

e) Rapido trawl bar lengths (author: Emilio Notti)

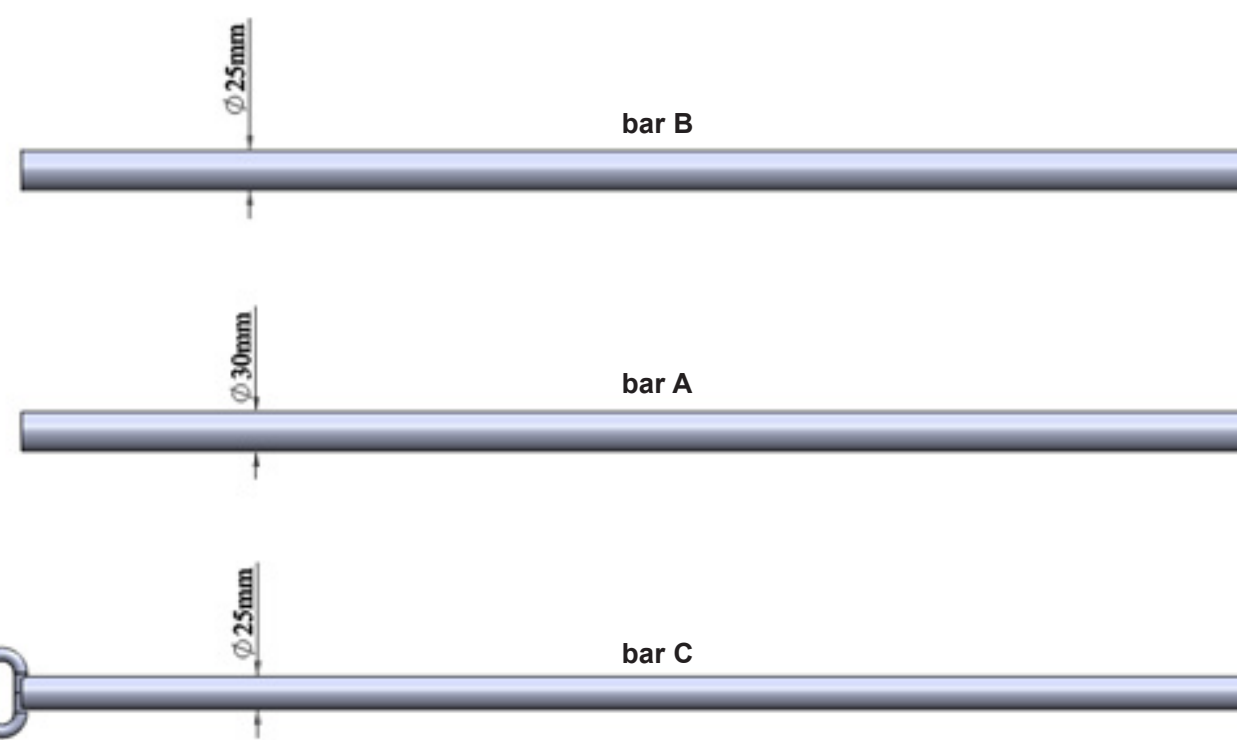

f) Rapido trawl bar diameters (author: Emilio Notti) 


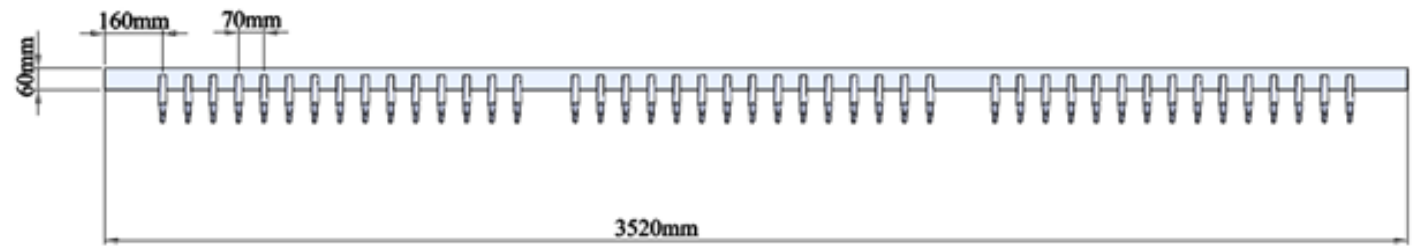

g) Rapido trawl blade scheme from above, 3 order of teeth 15 per order (author: Emilio Notti)

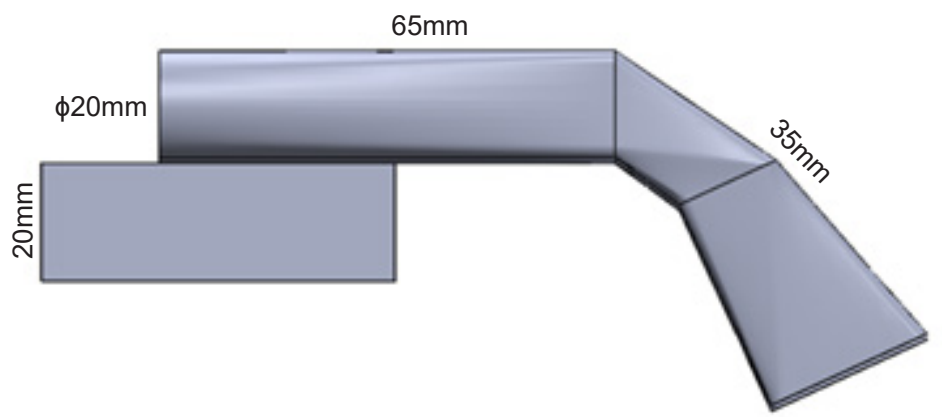

h) Rapido trawl blade from the side, square end of the knife $1 \mathrm{~cm}$ below the bottom plane of the sledge (author: Emilio Notti)

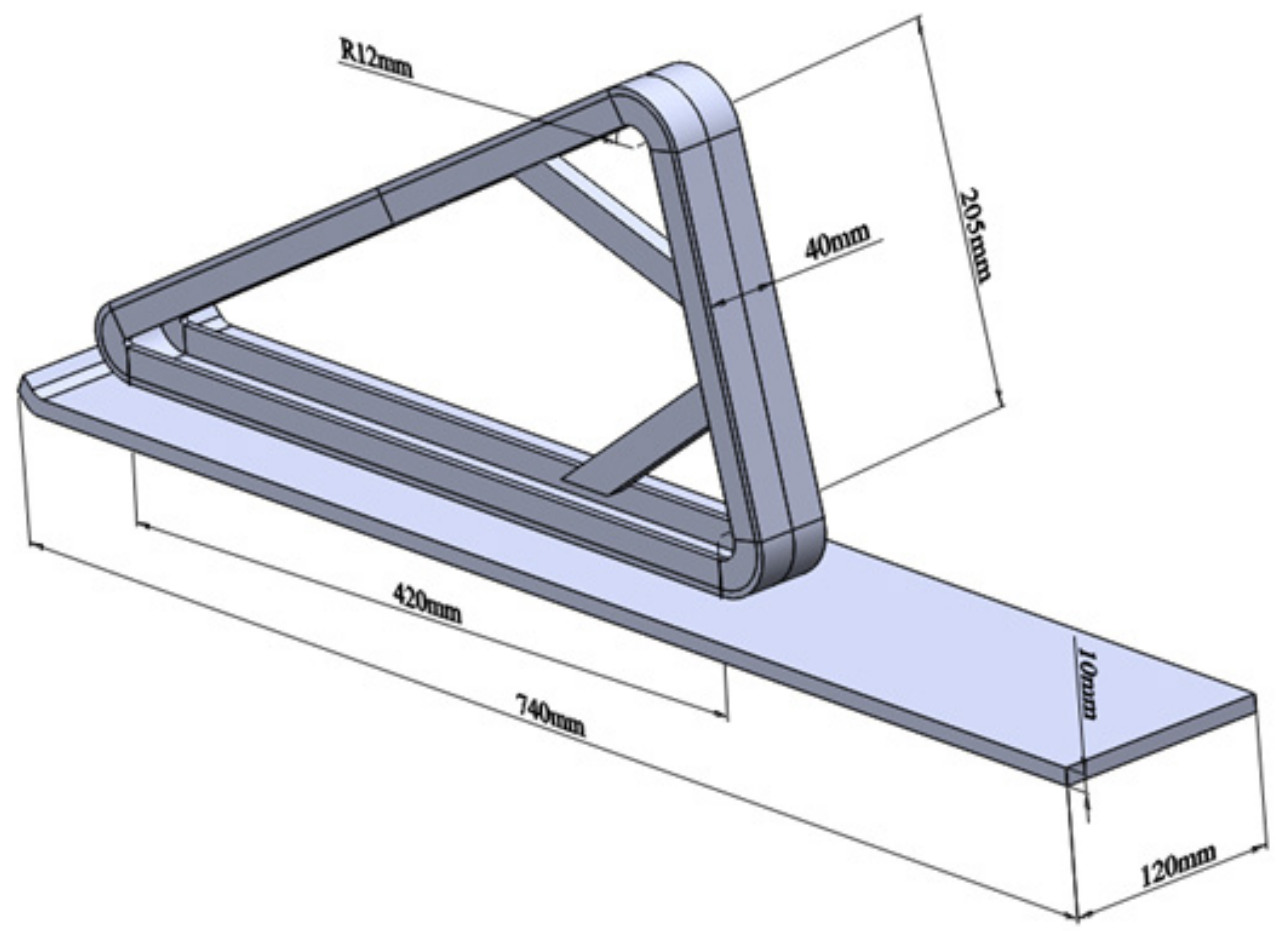

i) Rapido trawl frame, sledge dimensions (Author: Emilio Notti) 


In the Mediterranean and the Black Sea, the assessment of demersal stocks mainly relies on scientific surveys (bottom and beam trawl) while the assessment of pelagic stocks is essentially based on acoustic surveys using acoustic techniques with mid-water trawling. These routine surveys-at-sea provide essential information to monitor changes in the distribution of species and to perform annual estimates of total mortality, growth parameters, sex ratio and average length-at-maturity, which in turn are crucial to fine-tune the assessments of the status of resources and to estimate more precisely indicators at the population and fish community levels. However, survey practices differ from one subregion to another, each approach having its own strengths and limitations. In addition, there is still a lack of large-scale standardized surveys aimed at analysing the diversity and distribution of the main demersal and pelagic species across the Mediterranean and the Black Sea. One way of tackling this issue is to carry out international scientific surveys covering the main demersal and pelagic stocks based on a common methodology. The methodology presented in this publication aims at supporting the planning and implementation of regional demersal (bottom and beam) trawl and pelagic acoustic surveys. It can be useful for the implementation of new surveys-at-sea in areas where demersal trawl and pelagic acoustic surveys are not regularly carried out. It can also contribute to increasing comparability between existing surveys thanks to the standardization of methods, sampling of catches and data recording and analysis. Finally, it represents a valuable tool to define minimum requirements towards sustainability and management objectives at the regional and subregional level.

With the financial support of

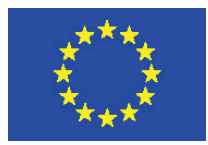

ISBN 978-92-5-132555-1 ISSN 2070-7010

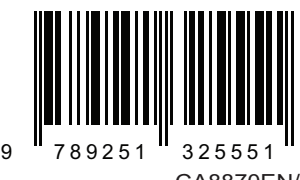

